NBER WORKING PAPER SERIES

\title{
RACIAL DISPARITIES IN THE HEALTH EFFECTS FROM AIR POLLUTION: EVIDENCE FROM PORTS
}

\author{
Kenneth Gillingham \\ Pei Huang \\ Working Paper 29108 \\ http://www.nber.org/papers/w29108 \\ NATIONAL BUREAU OF ECONOMIC RESEARCH \\ 1050 Massachusetts Avenue \\ Cambridge, MA 02138 \\ July 2021
}

The authors gratefully acknowledge the constructive feedback from Janet Currie, Matt Kotchen, Robert Mendelsohn, Kyle Meng, Marten Ovaere, Stephanie Weber, Richard Woodward, and the participants at many conferences and seminars, including the 8th IZA Workshop on Environment, Health and Labor Markets and the AERE Summer Conference. This publication was developed under Assistance Agreement No. RD835871 awarded by the U.S. Environmental Protection Agency (EPA) to Yale University. It has not been formally reviewed by EPA. The views expressed in this document are solely those of the authors and do not necessarily reflect those of the Agency, nor of the National Bureau of Economic Research. EPA does not endorse any products or commercial services mentioned in this publication.

NBER working papers are circulated for discussion and comment purposes. They have not been peerreviewed or been subject to the review by the NBER Board of Directors that accompanies official NBER publications.

(C) 2021 by Kenneth Gillingham and Pei Huang. All rights reserved. Short sections of text, not to exceed two paragraphs, may be quoted without explicit permission provided that full credit, including $\odot$ notice, is given to the source. 
Racial Disparities in the Health Effects from Air Pollution: Evidence from Ports

Kenneth Gillingham and Pei Huang

NBER Working Paper No. 29108

July 2021

JEL No. D63,I14,Q51,Q53,Q58,R41

\begin{abstract}
$\underline{\text { ABSTRACT }}$
This study examines the uneven effects of air pollution from maritime ports on physical and mental health across racial groups. We exploit quasi-random variation in vessels in port from weather events far out in the ocean to estimate how port traffic influences air pollution and human health. We find that one additional vessel in a port over a year leads to 3.0 hospital visits per thousand Black residents within 25 miles of the port and only 1.0 per thousand for whites. We assess a port-related environmental regulation and show that the policy can help alleviate racial inequalities in health outcomes.
\end{abstract}

\author{
Kenneth Gillingham \\ School of the Environment \\ Yale University \\ 195 Prospect Street \\ New Haven, CT 06511 \\ and NBER \\ kenneth.gillingham@yale.edu \\ Pei Huang \\ ZEW - Leibniz Center for \\ European Economic Research \\ L7, 1 \\ 68161 Mannheim \\ Germany \\ pei.huang@zew.de
}




\section{Introduction}

Air pollution is well known to negatively affect human health, most notably by contributing to respiratory and cardiovascular illnesses. More perniciously, the health effects are often unevenly distributed across the population, with some groups facing higher pollution exposures (e.g., Currie, 2011; Colmer et al., 2020; Currie et al., 2020) and worse health outcomes (e.g., Chay and Greenstone, 2003b; Currie and Walker, 2011; Deschênes et al., 2017). There are rising concerns about environmental justice in the United States due to these disproportionate exposures and health outcomes. Indeed, a key plank of President Joseph Biden's campaign platform involved improving environmental and health outcomes for communities of color. ${ }^{1}$

This paper examines racial inequity in health outcomes due to air pollution around a major point source of air pollution: maritime ports. ${ }^{2}$ It also explores the sources of this inequity, which could include differences in pollution exposure as well as differing responses to such exposure. Port facilities are especially important to study not only because they produce substantial pollution but also because they tend to be located in highly populated and low-income areas. Around 39 million people live within close proximity to ports in the United States (EPA, 2016), and many are people of color (Houston et al., 2008). For example, Long Beach, California, has one of the largest ports in the country and is 70\% non-white. In standard port activities, marine ships, trucks, and cargo-handling equipment often burn highly polluting fossil fuels, such as bunker fuel and diesel fuel. Yet emissions from port activities tend to be poorly regulated.

In this study, we estimate the contemporaneous effects of port activity-related air pollution on physical and mental health, focusing on racial disparities in health outcomes. The analysis consists of three steps. We first leverage quasi-experimental variation from distant oceanic events several days prior that exogenously shift the vessel tonnage or counts in port to identify the causal impact of port traffic on air pollution. The intuition for our identification strategy is that lagged distant storms far out in the ocean will change the path of ships and delay arrivals into port but do not otherwise affect the weather or non-port-related economic activity in areas surrounding the ports.

In the second step, we estimate the causal effect of daily pollution concentrations on hospitalizations in port areas using quasi-random variation from the vessel tonnage in ports (as predicted by distant oceanic storms several days prior) and local wind conditions. Our results indicate that the health impact on the Black population is three times the

\footnotetext{
${ }^{1}$ See https://joebiden.com/climate-communities-of-color/.

${ }^{2}$ Throughout the rest of the paper, we use the term "ports" to refer to oceanic maritime port facilities. We do not consider inland river or lake ports.
} 
impact on the white population. We finally use a regression discontinuity design and dynamic simulation to analyze a regulation that reduces fossil fuel use in ports to show how policy can substantially reduce inequality in health outcomes.

We find several compelling results. First, we show that a one percent increase in vessel tonnage in port increases pollution concentrations for major air pollutants by $0.3-0.4 \%$ within a 25-mile radius of the 27 largest ports in the United States. Second, we show that air pollution is responsible for hospitalizations related to respiratory, heart, and psychiatric problems near ports, and the Black population is disproportionately impacted. We find that one additional average-tonnage vessel in a port over a year leads to 3.0 hospital visits per thousand Black residents within 25 miles of a major port in California and only 1.0 hospital visits per thousand whites. We also provide evidence demonstrating differences in pollution exposure and suggestive evidence of differences in the response to exposure, indicating that the inequity in hospital admissions likely comes about from both sources. Our results further show that a policy in California to reduce fossil fuel use in ports significantly reduces pollutant concentrations, disproportionately benefiting the Black population. The reduced pollution leads to 9.9 avoided hospital visits per thousand Black residents per year and 3.4 avoided hospital visits per thousand white residents.

This paper makes several important contributions to the literature. The paper contributes to the economic literature on environmental inequalities by demonstrating how a major point source of pollution leads to unequal health outcomes for minority populations and how policy can ameliorate this inequality. This relates to the literature documenting how low-income, minority groups are more likely than other groups to live adjacent to environmental risks, such as Superfund hazardous waste sites (Currie, 2011) and power plants (Davis, 2011). In addition, an emerging body of economic literature provides estimates of heterogeneous marginal damages of pollution exposure, suggesting that disproportionate pollution exposure or differing ability to cope with pollution damages may translate into inequitable health and well-being (e.g., Chay and Greenstone, 2003b; Currie and Walker, 2011; Knittel et al., 2016; Schlenker and Walker, 2016; Alexander and Currie, 2017). Our paper is the first to examine inequality due to emissions from port facilities, enriching our knowledge of the drivers of unequal health outcomes across racial groups.

Our paper also contributes to the growing literature identifying the relationship between air pollution and human health using quasi-experimental methods (e.g., Chay and Greenstone, 2003a,b; Currie and Neidell, 2005; Currie and Walker, 2011; Deryugina et al., 2019). ${ }^{3}$ In many respects, our paper is most conceptually related to studies that estimate

\footnotetext{
${ }^{3}$ Epidemiological studies have also examined the effect of air pollution on human health. This paper contributes to the literature by providing quasi-experimental evidence on the effect of short-run exposure to
} 
the impact of air pollution on health using transportation traffic as the source of variation in air pollution (Moretti and Neidell, 2011; Schlenker and Walker, 2016; Knittel et al., 2016). For example, Moretti and Neidell (2011) estimate the effect of air pollution on respiratory-related hospitalizations, using variation in local air pollution from moving vessels in the Port of Los Angeles. Our paper differs in several fundamental ways. Our focus is on racial disparities in health consequences. But equally importantly, our empirical strategy is quite different in using lagged distant storms far out in the ocean as an exogenous source of variation. In this sense, our empirical strategy can be seen as more conceptually similar to how Schlenker and Walker (2016) use congestion in distant airports (possibly caused by weather) to provide an exogenous source of variation in air pollution around airports. In addition, our port traffic measure is more comprehensive in including both moving and docked vessels. Docked vessels are major emitters of air pollution due to diesel-fired auxiliary electricity generators. We also study a large set of ports and health outcomes, providing a rich picture of the causal impacts relevant to policy.

Finally, to the best of our knowledge, we provide the first quasi-experimental evidence that short-term exposure to air pollution influences mental health differently across racial groups using patient-level hospital records in the United States. ${ }^{4}$ Related work examines the effects of air pollution on a variety of measures of human physical health, including the studies mentioned above, but neglecting mental health impacts underestimates the overall effect of air pollution in a non-negligible way. By including mental health, our work contributes to the broader literature suggesting that air pollution affects human behavior and well-being (Graff Zivin and Neidell, 2013), such as diminished labor productivity (e.g., Graff Zivin and Neidell, 2012; Hanna and Oliva, 2015; Chang et al., 2016; Borgschulte et al., 2018; Chang et al., 2019), reduced cognitive performance (e.g., Sanders, 2012; Ebenstein et al., 2016; Bishop et al., 2018), increased criminal activities (e.g., Burkhardt et al., 2019; Bondy et al., 2020; Herrnstadt et al., 2021), and inflated road accidents (e.g., Sager, 2019). Some of these outcomes, such as criminal activities and road accidents, may even come about partly due to the impact of air pollution on mental health.

The paper proceeds as follows. Section 2 provides a brief background on port pollution and human health. Section 3 describes our data and descriptive statistics. Section 4 discusses our empirical strategies and identification. Section 5 presents the main empirical results. Section 6 discusses implications for policy, and Section 7 concludes.

air pollution on health that addresses several key estimation challenges.

${ }^{4}$ In concurrent related work, Ordonez (2020) estimates the effects of air pollutants from fossil-fuel power plants on mental health in Colombia using a quasi-experimental framework and patient-level records. Zhang et al. (2017) and Chen et al. (2018) find an effect of air pollution on mental health based on stated evidence (i.e., survey data) in China. 


\section{Background}

\subsection{Air Pollution in Ports}

Ports serve as a primary conduit for global trade and play a significant role in the local economies for many coastal cities (EPA, 2017). The Organisation for Economic Co-operation and Development (OECD) projects that global marine freight will more than quadruple by 2050, and this expansion is expected to increase port activities further. ${ }^{5}$ Docked vessels in ports can be one of the dirtiest emitters in terms of local air pollutants, as they often operate auxiliary engines to generate onboard electricity by burning bunker fuel and diesel (Wan et al., 2016). Other diesel-powered activities in ports, such as cargo handling equipment, automated guided vehicles, and short-haul trucks, also emit a substantial amount of air pollution (Agrawal et al., 2009). Hence, ports can be one of the largest contributors to air pollution in surrounding regions. ${ }^{6}$ It is notable that approximately $30 \%$ of counties in the United States that are currently out of compliance or previously failed to meet the National Ambient Air Quality Standards (NAAQS) either include or are adjacent to major ports (see Figure B.1). ${ }^{7}$

Most ports are located in urban areas with high population density (e.g., Los Angeles and New York), often surrounded by low-income, minority neighborhoods. For example, around $40 \%$ of zip codes within a 25 -mile radius of the major ports in California are designated as "disadvantaged" communities, with concentrations of people that are of low income, color, high unemployment, and/or low levels of educational attainment. ${ }^{8}$ These low-income households and people of color living or working in port areas can be significantly impacted by air pollution (Houston et al., 2014). Many studies have consistently documented differences in air pollution exposure across socioeconomic groups (see recent reviews in Mohai et al., 2009; Banzhaf et al., 2019a,b; Hsiang et al., 2019), and ports are likely one contributing factor for these differences.

${ }^{5}$ See https://www.itf-oecd.org/sites/default/files/docs/2015-01-27-outlook2015.pdf.

${ }^{6}$ See https://www.latimes.com/california/story/2020-01-03/port-ships-are-becoming-la-worstpolluters-regulators-plug-in.

${ }^{7}$ The National Ambient Air Quality Standards are specified under the Clean Air Act in the United States, which determines maximum allowable concentrations of criteria air pollutants that have been proved to be harmful to human health.

${ }^{8}$ Disadvantaged communities in California are often disproportionately impacted by environmental hazards. They are determined based on Senate Bill 535 (SB 535). The bill requires a proportion of the revenue from the Cap-and-Trade program auction to be allocated to projects that benefit disadvantaged communities. The designation of disadvantaged communities uses the CalEnviroScreen tool, a scoring system with several factors: pollution burden and socioeconomic characteristics. 


\subsection{Air Pollution and Health}

Air pollution is well known to be detrimental to human health (Dockery et al., 1993). Breathing in polluted air can affect lung development and cause respiratory diseases (Dockery and Pope III, 1994), such as asthma and chronic obstructive pulmonary disease (DeVries et al., 2017; Wang et al., 2019). Epidemiologists have also established an association between air pollution and cardiovascular disease (Seaton et al., 1995), including impairing blood vessel function (Riggs et al., 2020), speeding up artery calcification (Keller et al., 2018), and increasing risk of hemorrhagic stroke (Sun et al., 2019). Moreover, studies have also shown an association between air pollution and breast and lung cancer (Cheng et al., 2020).

A growing number of economic studies use quasi-experimental methods to estimate the causal effects of air pollution exposure on human health, using health metrics such as infant mortality and birth outcomes (e.g., Chay and Greenstone, 2003b; Currie and Neidell, 2005; Currie et al., 2009; Currie and Walker, 2011; Sanders and Stoecker, 2015; Arceo et al., 2016; Alexander and Schwandt, 2019), adult mortality (e.g., Deryugina et al., 2019; Anderson, 2020), respiratory problems (e.g., Moretti and Neidell, 2011; Schlenker and Walker, 2016), and cardiovascular diseases (e.g., Schlenker and Walker, 2016; Halliday et al., 2019). While the focus of much of the literature has been on physical health, there is growing epidemiological work showing an association between air pollution and mental health (e.g., Sass et al., 2017; Kim et al., 2018; Brokamp et al., 2019).

Air pollution could adversely affect mental health through several channels. Air pollution can lead to neuroinflammation and oxidative stress linked to anxiety, depression, and cognitive dysfunction (Sørensen et al., 2003; Salim et al., 2011). In addition, people tend to reduce outdoor activities due to pollution, which may induce mental disorders through pathways such as vitamin D deficiency from limited access to sunlight (Anglin et al., 2013), reduced exercise (Suija et al., 2013), restricted access to green space (Cohen-Cline et al., 2015), and less social support (George et al., 1989). Moreover, some studies suggest that worsened physical health caused by air pollution exposure may also lead to fear and stress, which increases anxiety and other mental illnesses (Scott et al., 2007).

\section{Data and Descriptive Statistics}

This paper compiles a comprehensive data set from multiple sources on port traffic, air pollution, health, local weather, and major oceanic storms. 


\subsection{Port Traffic}

We obtain port data from the U.S. Army Corps of Engineers (USACE) for 2001-2016. The data contain dates on which ships enter and exit from ports, including container ships, bulk carriers, tanker ships, and passenger ships. We match the entrance and clearance records for each vessel visit based on vessel names or identity numbers, from which we can approximate the number of days a vessel is at berth in a port. ${ }^{9}$ For each date in a port, we then calculate gross vessel tonnage and the number of vessels, which serve as the core port traffic measures for this study. Since different vessel types have different sizes and weights, the calculated gross vessel tonnage variable represents vessel heterogeneity to some extent.

One minor weakness of these data is that USACE mainly tracks waterborne transportation originating from or heading to foreign ports and does not have complete coverage of ships traveling between domestic ports. According to the Bureau of Transportation Statistics, foreign waterborne freight accounts for $85-90 \%$ of total shipping tonnage in maritime ports in the United States. ${ }^{10}$ Hence, the USACE data should be a reasonable representation of total vessel tonnage in the included ports in this study, even if it misses a small fraction of the tonnage. This minor caveat about our data is analogous to one in Schlenker and Walker (2016), where the data set they use for airport traffic only accounts for major domestic airline passenger travel.

Table A.1 contains the summary statistics of daily vessel tonnage and counts. In our final data set, we focus on the 27 major maritime ports in the United States, six of which are in California. ${ }^{11}$

\subsection{Air Pollution}

We obtain daily air pollution concentration data from U.S. Environmental Protection Agency (EPA) Air Quality System (AQS) for five local air pollutants, carbon monoxide (CO), nitrogen dioxide $\left(\mathrm{NO}_{2}\right)$, ozone $\left(\mathrm{O}_{3}\right)$, fine particulate matter $\left(\mathrm{PM}_{2.5}\right)$, and sulfur dioxide $\left(\mathrm{SO}_{2}\right)$, for 2001-2016. The data contain daily maxima and means of pollution concentrations at the pollution monitoring site level. ${ }^{12}$

\footnotetext{
${ }^{9}$ The data contain some unmatched vessel entrance or clearance records. We treat these entries as a single day in port since most vessels in the data sample enter and exit from ports on the same day.

${ }^{10}$ This estimate is obtained from https://www.bts.gov/content/us-waterborne-freight.

${ }^{11}$ The six major California ports are the Ports of Long Beach, Los Angeles, Oakland, San Diego, Hueneme, and San Francisco.

${ }^{12}$ The EPA AQS reports various daily means with different time windows that air passes through the monitoring device before it is analyzed. For example, for $\mathrm{CO}$ at certain monitoring sites, there are one-hour and eight-hour run daily averages. We take averages for each monitor and day.
} 


\subsection{Health}

We obtain patient-level administrative data from the California Office of Statewide Health Planning and Development for 2010-2016. These include three types of data: Patient Discharge Data (PDD), Emergency Department Data (EDD), and Ambulatory Surgery Center Data (ASCD). The PDD consists of overnight stays from all California hospitals. The EDD and ASCD keep track of patients who had single-day emergency treatment in an Emergency Room or licensed freestanding Ambulatory Surgery Centers. Any patient initially logged in the EDD/ASCD that is subsequently admitted to a hospital for overnight stays is dropped in the EDD/ASCD and then added to the PDD to eliminate double-counting and ensure consistency.

These three data sets provide dates for hospital visits, the zip codes of home addresses, demographics (age, sex, and race), one principal diagnosis, and up to 24 secondary diagnoses. In our primary specification, we pool the three data sets and count the daily number of hospital visits at each zip code for patients who had either a principal or secondary diagnosis related to the health problems examined in this paper. ${ }^{13}$ We then merge in population data from the 2010 U.S. Census. ${ }^{14}$ We next calculate the daily hospitalization rate at the zip code level, indicating the number of hospital visits per million residents per day. We focus on hospitalizations of six categories of illnesses: respiratory (asthma, acute upper respiratory, all respiratory), mental (anxiety, all psychiatric), and heart-related. We also include three diseases for placebo checks: arterial embolism (i.e., stuck blood clots), external neck wounds, and appendicitis. ${ }^{15}$ Figure B.2 illustrates that our sample includes large sections of the largest urban areas in California.

\subsection{Weather}

We acquire weather data from the National Oceanic and Atmospheric Administration (NOAA) Integrated Surface Database for 2001-2016. We construct daily measures of weather variables from hourly readings at the weather station level. These variables include

\footnotetext{
${ }^{13}$ We conduct several robustness checks by exploring only principal diagnoses and each of the three data sets separately.

${ }^{14}$ U.S. Census data is based on the zip code tabulation area (ZCTA), so we merge in based on the ZCTA. We exclude the ZCTAs with fewer than 5,000 residents (or those with fewer than 1,000 residents in each socioeconomic group for heterogeneity analysis), which only accounts for $2 \%$ of the total California population. For the remainder of the paper, we refer to 'zip codes' for simplicity.

${ }^{15}$ The administrative data sets adopt what are called 'ICD codes' to record diagnoses. In October 2015, the codes were upgraded from ICD-9-CM codes to the ICD-10-CM codes. Table A.2 presents the ICD codes for this study. The codes that fall into the psychiatric categories follow Brokamp et al. (2019) by excluding those associated with suicides. The table also presents the corresponding Medicare Severity Diagnosis Related Group (MS-DRG) codes for calculating the medical costs of illnesses from the Medicare data.
} 
dew point, minimum and maximum temperatures, precipitation, wind speed, and wind direction. The minimum and maximum temperatures are the lowest and highest hourly readings in a day, and the daily precipitation is the summation of hourly records. ${ }^{16} \mathrm{We}$ then calculate daily means for dew point temperature, wind speed, and wind direction. The wind direction blowing north is normalized to zero, and it increases up to 360 degrees clockwise.

\subsection{Tropical Cyclones}

Tropical cyclones are rapidly rotating storms that originate in the tropical oceans. Those occurring in the northeastern Pacific Ocean or the Atlantic Ocean are called hurricanes, while those in the northwestern Pacific Ocean are called typhoons. We obtained tropical cyclone data from the NOAA National Hurricane Center for 2001-2016. The data track dates, times, center locations, maximum wind, central pressure, and wind radii of historical cyclones every six hours in the Northeast and North-central Pacific Ocean and the Atlantic Ocean.

Figure 1(a) shows all hurricanes that occurred in 2016 and the locations of the 27 major ports in the United States. The figure shows that cyclones can strike ports, which may directly impact local weather and air pollution. Our primary results only use data when cyclones are at least 500 miles away from the 27 major ports to avoid any direct impacts. We chose 500 miles because cyclones are documented to have a typical radius in the range of 125-310 miles, so we can be assured that the ports are well outside the scope of the cyclones included in our study. ${ }^{17}$ The path of cyclones at least 500 miles away from ports can be seen in the colored dotted lines in Figure 1(a).

Tropical cyclones are especially useful for our study because they can dramatically affect the number of ships and gross tonnage in port. For example, StormGeo-a global weather service provider-observes that "[t]ropical cyclones [raging in the ocean] have an enormous impact on ships and shipping logistics. Entire supply chains can be disrupted when ships are delayed due to the presence of a cyclone." 18 To illustrate this effect, Figure 1(b) shows how two paths of ships headed for U.S. ports were taken off track by Hurricane Leslie from August 30 to September 12, 2012. Typically, vessels would take the efficient routes following the shortest distances (the dashed lines) to travel between ports. In this

\footnotetext{
${ }^{16}$ For missing hourly precipitation readings, we assume they are the same as the most recent available reading.

${ }^{17}$ See $\quad$ https://public.wmo.int/en/our-mandate/focus-areas/natural-hazards-and-disaster-riskreduction/tropical-cyclones.

${ }^{18}$ See https:/ / www.stormgeo.com/products/s-suite/s-routing/articles/the-effects-of-tropical-cycloneson-shipping/.
} 
case, we have ships traveling from the Port of Marseille, France, to the Port of Houston and the Port of Santos, Brazil, to the Port of New York and New Jersey. Around September 8, 2012, the vessels took longer alternative routes (the solid lines) to avoid Hurricane Leslie, which led to additional transit time and delays in reaching their final destinations. This influence of distant storms on shipping paths will provide an exogenous source of variation in our study, as will be discussed.

\subsection{Data Compilation}

We compile two data sets for this study. For the analysis of air pollution, we construct the data at the paired monitor-port level with the following steps: (1) we map all pollution monitors within a 25-mile radius of the 27 major ports; ${ }^{19}$ (2) we calculate the Vincenty distance and direction between a monitor and its mapped port based on their latitudes and longitudes; ${ }^{20}$ (3) we select all weather stations within a 50-mile radius of pollution monitors and calculate inverse distance-weighted averages of weather measures at the monitor level; and (4) we calculate the relative wind direction between a monitor and a port to determine whether a monitor is downwind or upwind of its paired port, i.e., the difference in angles between the wind direction observed at a monitor and a perpendicular ray from the port to the monitor.

For our analysis of health impacts, we construct the data at the paired zip code-port level with similar steps: (1) we select all zip codes within a 25-mile radius of the six major ports in California; (2) we calculate the Vincenty distance and the relative direction between a paired zip code and port; (3) we calculate the zip code-level pollution measures by taking inverse distance-weighted averages of the monitor-level data within 25 miles of zip code centroids; (4) we calculate zip code-level weather measures by selecting all weather stations within 50 miles of zip code centroids and take inverse distance-weighted averages.

Table A.3 contains the summary statistics for the main variables (i.e., port traffic, pollution, and hospitalization rate) in this study. Tables A.4-A.8 present the summary statistics of hospitalization rates for various slices of the data.

\footnotetext{
${ }^{19}$ In our data set, a monitor can be mapped to multiple ports, since ports can be close to each other (e.g., Ports of Los Angeles and Long Beach).

${ }^{20}$ Vincenty distance is a commonly used distance measure between two points on the surface of a spheroid developed by Thaddeus Vincenty (for examples of economics papers adopting this distance measure, see Auffhammer and Kellogg (2011) and Currie et al. (2017)). The distance measure assumes that the shape of the Earth is an oblate spheroid, which is more accurate than other distance measures, such as great-circle distance, which assume a spherical Earth.
} 


\subsection{Descriptive Statistics on Racial Disparities}

Before diving into the empirical modeling, we present descriptive statistics on racial disparities in pollution exposure and hospitalizations near ports in California. Following Currie et al. (2020), we primarily focus on comparing non-Hispanic white and Black populations in this paper because the disparities between these two groups have been well-documented (Boustan, 2012; Boustan et al., 2016). In addition, the Hispanic ethnic identity is often described as more fluid over time than non-Hispanic white or Black groups, which may introduce measurement errors in comparing Hispanics and non-Hispanics (Liebler et al., 2017). However, for the interested reader, we also present some descriptive statistics for Hispanics in Figure B.3.

Figure 2(a) shows distributions of the Black and white populations residing in California port areas by distance to their nearest mapped ports. We observe that the Black population tends to live closer to ports, while the white population is more uniformly distributed, suggesting that ports may disproportionately impact Blacks simply due to differences in exposure to air pollution.

Figure 2(b) presents distributions of populations for the two racial groups by decile of mean $\mathrm{PM}_{2.5}$ exposure at the zip code level over 2010-2016. We see that Blacks live in areas that are exposed to higher pollution concentrations than whites. As further evidence, Table A.9 presents the average pollution exposure for Blacks and whites in port areas, weighted by the population of each race at the zip code level. ${ }^{21}$ The evidence indicates that Blacks face substantially higher exposure to air pollution in areas around ports than whites.

Next, we examine the racial gaps in health outcomes. Figure 3 plots probability density functions of annual hospitalization rates for the Black and white populations for zip codes within $0-12.5$ miles to ports and zip codes within $12.5-25$ miles to ports. ${ }^{22}$ In both panels, the distributions for the Black population lie to the right of the distributions for whites. The gaps in mean hospitalization rates between Blacks and whites become slightly wider closer to ports. Further, Figure B.4 shows that annual air pollution exposure for individuals visiting hospitals is notably higher for Blacks than whites. These figures provide descriptive evidence of racial disparities in pollution exposure and health outcomes in port areas.

\footnotetext{
${ }^{21}$ This analysis focuses on differences in exposure across zip codes and ignores any within-zip code differences in exposure, so it may slightly underestimate disparities in pollution exposure. That said, this approach is standard in the literature (see a review of this approach in Banzhaf et al. (2019b)).

${ }^{22}$ The corresponding boxplots are shown in Figure B.5.
} 


\section{Empirical Strategy}

\subsection{Effect of Vessels in Ports on Air Pollution}

We begin our analysis by estimating the effect of port traffic on daily air pollution concentrations. Our empirical specification is as follows:

$$
P_{i p t}=\beta V_{p t}+\mathbf{X}_{i t} \theta+\delta_{t}+\mu_{i p}+e_{i p t},
$$

where $P_{i p t}$ is the $\log$ of local air pollutant concentrations at monitor $i$ that is mapped to port $p$ on day $t$. The variable $V_{p t}$ is either the $\log$ of the gross vessel tonnage or the number of vessels in port. The set of variables $\mathbf{X}_{i t}$ includes weather controls consisting of maximum, minimum, and dew point temperatures; precipitation; wind speed; and relative wind direction (indicating whether a monitor is downwind or upwind of the mapped port). $\mathbf{X}_{i t}$ also includes quadratic terms for each of the weather controls (except for the relative wind direction). We incorporate temporal fixed effects $\delta_{t}$ that consist of county-by-year, month, day-of-week, and holiday fixed effects. ${ }^{23}$ Since there may be unobserved time-invariant effects, we further include monitor-port fixed effects $\mu_{i p} . e_{i p t}$ is the error term. The parameter of interest, $\beta$, can be interpreted as the effect of port traffic on local air pollutant concentrations for a given day.

There are several potential concerns in estimating equation (1) using ordinary least squares (OLS) that may lead to biased estimates of $\beta$. One concern is that there may be some measurement error in the port traffic measures because we observe vessels originating from or heading to foreign ports (85-90\% of tonnage), so we miss some vessels in our analysis. A second concern is the possibility of omitted variables, such as unobserved economic or weather factors that affect port traffic and local air pollution.

To address these concerns, our empirical approach leverages quasi-random variation from distant tropical cyclones several days prior to the day under consideration. Specifically, we instrument for $V_{p t}$ using the existence of lagged tropical cyclones far out in the ocean. As mentioned above, these cyclones often disrupt travel for marine vessels, delaying their arrival into ports, leading to fewer ships and less tonnage in ports several days later (recall Figure 1). The first stage relies on this disruptive impact on shipping.

To be precise, the first stage of our instrumental variables approach is:

$$
V_{p t}=\alpha T C_{t-m}+\mathbf{W}_{i p t} \lambda+\epsilon_{i p t},
$$

${ }^{23}$ The holidays include New Year, Martin Luther King Jr. Day, Presidents Day, Memorial Day, Independence Day, Labor Day, Columbus Day, Veterans Day, Thanksgiving, and Christmas, as well as the three-day prior and post the holiday. 
where $T C_{t-m}$ is an indicator variable equal to one if there are one or more tropical cyclones far out in the ocean (i.e., at least 500 miles away from ports) on day $t-m$. We use a seven-day lag $(m=7)$ in our primary specification, but we run robustness checks with different lags. A cyclone can last anywhere from a few days to weeks. Thus, to create this lagged variable, we first identify the days when there are one or more cyclones that are at least 500 miles away from ports, and then take the seven-day lag. ${ }^{24}$ The variable $\mathbf{W}_{i p t}$ includes the exogenous variables defined in equation (1): weather controls, temporal fixed effects, and monitor-port fixed effects.

To be a valid instrument, $T C_{t-m}$ must satisfy the exclusion restriction, i.e., it is uncorrelated with the error term $e_{i p t}$ in equation (1). ${ }^{25} \mathrm{~A}$ direct threat to the exclusion restriction would be if the tropical cyclones hit the ports several days later, directly affecting pollution. We avoid this concern by removing the observations during the days when cyclones appear within a 300-mile radius of ports. We also remove observations two days prior and after the cyclones are within a 300-mile radius to be even more confident that the direct threat is not an issue. Another concern could be that lagged distant cyclones not only impact vessel tonnage or counts in ports but also substantially influence the composition of vessels, which may, in turn, affect air pollution in ports. Figure B.6 shows that lagged tropical cyclones far out in the ocean do not appear to have any notable effect on the composition of vessel types in ports.

A more modest threat could be if lagged tropical cyclones far out in the ocean sufficiently impact meteorological patterns that they indirectly affect current-day weather in the ports. We explore this by dividing the sample into month-days when $T C_{t-7}=1$ and those when it is zero. Figure 4 shows distributions of the six weather variables across the two subsamples. ${ }^{26}$ The distributions between the two grouped samples are almost identical, confirming that the weather in the ports is no different when there are tropical cyclones in the distant ocean seven days prior than when there are not. ${ }^{27}$

Thus, for there to be remaining identification concerns, there would have to be some other localized source of air pollution that happens to be correlated with distant storms seven days earlier. This seems unlikely to us. But we will also perform a placebo test and a

\footnotetext{
${ }^{24}$ The choice of seven days is motivated both because it is a week after the storm was out at sea and because we to observe a drop in vessel tonnage in ports seven days later.

${ }^{25}$ We expect lagged distant tropical cyclones always to reduce the number of vessels and gross tonnage in ports, so the monotonicity condition should hold.

${ }^{26}$ Because the number of observations in the two subsamples is different, we randomly draw a subset of observations in the second subsample, so the number of observations is the same between the samples, but statistical tests of differences in means are no different if we use the each of the full subsamples.

${ }^{27}$ To provide further evidence, Table A.10 presents the standardized mean differences, variance ratio, and Kolmogorov-Smirnov statistics for the weather variables. We also create boxplots and empirical quantilequantile (QQ) plots for the weather variables (see Figures B.7 and B.8). Except for a few outliers, these supplementary figures confirm that the weather is no different.
} 
set of robustness checks to further support the instrument's validity.

\subsection{Effect of Air Pollution on Health}

To estimate the relationship between air pollution and health outcomes in port areas, we specify the following linear regression model:

$$
y_{i p t}=\beta P_{i p t}+\mathbf{X}_{i t} \theta+\delta_{t}+\mu_{i p}+e_{i p t},
$$

where $y_{i p t}$ is the hospitalization rate (i.e., hospital visits per million residents) associated with an illness in zip code $i$ that is mapped to port $p$ on day $t$. The variable $P_{i p t}$ is the air pollutant concentration. We run the regression separately for each of four pollutants- $\mathrm{CO}$, $\mathrm{NO}_{2}, \mathrm{PM}_{2.5}$, and $\mathrm{SO}_{2}$ - that are shown to be detrimental to human health. ${ }^{28}$ In an extension in Section 5.3, we also consider including sets of these pollutants that might be co-emitted. The remaining variables are similar to those specified in equation (1), where $\mathbf{X}_{i t}$ is a set of weather controls; $\delta_{t}$ is the set of temporal fixed effects; $\mu_{i p}$ is a zip code-port fixed effect. The coefficient of interest $\beta$ indicates the effect of a one-unit increase in air pollution concentrations on the daily hospitalization rate associated with an illness.

Again, estimating equation (3) using OLS may lead to a biased estimate of $\beta$. One potential concern is that exposure to air pollution is not randomly assigned to residents, and thus sorting of individuals may be present. People with preferences for better air quality may choose to live in cleaner areas or adjust their daily activities based on pollution forecasts. Another potential concern is that there may be measurement errors in pollution exposure. Our pollution measures at the zip code level may deviate from residents' actual exposure since we do not observe their exact home addresses. People are also unlikely to be stationary all the time. In addition, there may be omitted variables correlated with both air pollution and health. For example, unobserved macroeconomic factors may affect air pollution levels and bring about changes in income or health care access.

To address these concerns, we employ an over-identified instrumental variables approach (Knittel et al., 2016; Schlenker and Walker, 2016; Deryugina et al., 2019), where the

\footnotetext{
${ }^{28}$ In this choice of pollutants to study, we follow the existing evidence of the health effects of common air pollutants (e.g., Dominici et al., 2006; Bell et al., 2008; Brokamp et al., 2019).
} 
first-stage regression is specified as:

$$
\begin{aligned}
P_{i p t}= & \alpha_{1} \widehat{V}_{p t}+\alpha_{2} W S_{i t}+\sum_{s=1}^{7} \alpha_{3 s} W D_{i t}^{s}+\alpha_{4} \widehat{V}_{p t} \times W S_{i t}+\sum_{s=1}^{7} \alpha_{5 s} \widehat{V}_{p t} \times W D_{i t}^{s}+ \\
& \sum_{s=1}^{7} \alpha_{6 s} W S_{i t} \times W D_{i t}^{s}+\sum_{s=1}^{7} \alpha_{7 s} \widehat{V}_{p t} \times W S_{i t} \times W D_{i t}^{s}+\mathbf{W}_{i p t} \lambda+\epsilon_{i p t} .
\end{aligned}
$$

In this equation, $W S_{i t}$ represents wind speed. $W D_{i t}^{s}$ is an indicator variable for wind direction, which is equal to one if the daily mean wind direction in zip code $i$ falls in each 45-degree interval [45s, 45s+45), where $s \in\{1, \ldots, 7\}$ is the interval. ${ }^{29}$ The variable $\widehat{V}_{p t}$ is the fitted vessel tonnage in port $p$ on day $t$, which is obtained using the following regression:

$$
V_{p t}=\sum_{p} \gamma_{p} \mathbb{1}_{p} \times T C_{t-m}+\xi_{p t}
$$

where $T C_{t-m}$ is the tropical cyclone indicator variable. The variable $\mathbb{1}_{p}$ is an indicator for port $p$, which allows the effect of the instrument to vary across locations.

The intuition for the identification in this empirical strategy is that we are isolating and leveraging the variation in vessel tonnage that comes about because of distant tropical cyclones several days prior. ${ }^{30}$ This approach avoids using any variation in vessel tonnage related to localized economic or other factors that may also influence hospitalization rates. For there to be a remaining identification concern, one must believe that tropical cyclones in the distant ocean several days prior influence hospitalizations in areas around ports through a channel outside of port traffic. This seems unlikely.

Our specification also includes local wind direction and wind speed in the set of instruments, which adds statistical power because local wind affects the spatial distribution of air pollutants. A large body of meteorological literature has shown that wind direction and speed are strong predictors of local pollutant concentrations (e.g., Chaloulakou et al., 2003; Kukkonen et al., 2005; Karner et al., 2010). Based on this scientific evidence, a growing number of studies in the economics literature exploit variation in local wind as the driver for air pollution (e.g., Moeltner et al., 2013; Schlenker and Walker, 2016; Keiser et al., 2018; Deryugina et al., 2019; Bondy et al., 2020; Anderson, 2020; Herrnstadt et al., 2021).

\footnotetext{
${ }^{29}$ We exclude the interval $[0,45)$ in regressions as the base, and no observations fall in the interval [315, 360 ) in our data set, so this interval is also excluded. $\mathbf{W}_{i p t}$ includes the same weather controls (except for wind direction and wind speed) and fixed effects as in equation (2)

${ }^{30}$ Wooldridge (2002, p. 117) discusses the assumptions for using fitted variables as instruments, which requires the exogenous regressors for generating fitted instruments to be orthogonal with the error term in the main estimation equation, i.e., equation (3). See Dahl and Lochner (2012) and Schlenker and Walker (2016) for recent papers using fitted variables as instruments.
} 


\section{Results}

\subsection{Effect of Vessels in Port on Air Pollution}

We begin our analysis by demonstrating a causal relationship between port traffic and air pollution. We estimate the model given in equation (1) using two-stage least squares, with the existence of distant tropical cyclones seven days prior as the instrument. We perform this estimation using all 27 major ports in the United States. The standard errors are two-way clustered by monitor-port and day. ${ }^{31}$

In the first stage, we estimate equation (2). We find a strong first-stage relationship (Table A.11), consistent with lagged distant tropical cyclones affecting vessel tonnage and the number of vessels. ${ }^{32}$ The point estimates are all significant, suggesting that the existence of lagged distant tropical cyclones results in $0.4-0.5 \%$ less tonnage (or 0.5 fewer vessels) in ports per day. The first-stage F-statistics range from 31 to 37 in Panel A and from 13 to 20 in Panel B across columns in Table A.11. ${ }^{33}$ These are well above standard thresholds for weak instruments to be a concern (e.g., Andrews et al. (2019) suggest that instruments are weak below a threshold of ten). We also present two tests for weak instruments, the Anderson-Rubin Wald statistic and the related Stock and Wright (2000) LM S statistic. The null hypothesis of the two tests is that the coefficient of the endogenous variable is equal to zero in the structural equation (i.e., we have a weak instrument). The $p$-values for these two tests indicate that the null hypothesis is rejected at the $1-5 \%$ levels.

Estimating the second stage shows the effect of port traffic on the concentration of the four major air pollutants, which are shown in Table 1. Each entry is a separate estimation. Panel A shows the results using vessel tonnage as the covariate of interest, while Panel B shows the results using the number of vessels as the covariate of interest. Using vessel tonnage accounts for the fact that larger ships with greater capacity are more likely to have greater emissions. In contrast, using the number of vessels allows for a straightforward interpretation by quantifying the effect of an average ship. Hence, we show both. All results include county-by-year, day-of-week, holiday, and monitor-port fixed effects.

The results in Table 1 show a significant effect of both vessel tonnage and the number of vessels on pollution concentrations for $\mathrm{CO}, \mathrm{NO}_{2}, \mathrm{PM}_{2.5}$, and $\mathrm{SO}_{2}$. Looking across the

\footnotetext{
${ }^{31}$ We cluster by monitor-port because we exploit the relative wind direction between a port and monitor, and a monitor can be mapped to multiple ports.

${ }^{32}$ The specifications are the same across the columns. The number of observations differs across columns due to the minor differences in data availability for each pollutant.

${ }^{33}$ All first-stage F statistics reported in this paper are cluster-robust Kleibergen-Paap Wald F statistics (Kleibergen and Paap, 2006), which are much smaller than the standard Cragg-Donald Wald F statistics assuming i.i.d. errors (not reported in the paper) (Cragg and Donald, 1993).
} 
columns, we find that a one percent increase in vessel tonnage in a port in a day results in $0.25-0.43 \%$ increases in pollution concentrations within a 25-mile radius of the port. The results in Panel B can help to contextualize the results better and indicate that one additional vessel in a port in a day results in $2-4 \%$ increases in pollution concentrations within a 25-mile radius of the port. This increase in pollution from added port traffic can be interpreted as the combined effect from the direct emissions from the additional ship in port and the indirect emissions due to the complementary activities associated with handling goods from the ship. For example, cargo handling equipment and short-haul trucks are often powered with diesel fuel and can be expected to add to the emissions from the ship itself.

In contrast to the pollutants in Table $1, \mathrm{O}_{3}$ is a secondary pollutant, which is formed through complex chemical reactions with $\mathrm{NO}_{x}$ and volatile organic compounds (VOCs) in the presence of warm temperatures and sunlight. ${ }^{34} \mathrm{Yet}_{3}$ is well-known to negatively affect human health (Auffhammer and Kellogg, 2011). We thus conduct the same analysis for $\mathrm{O}_{3}$ in Table A.12 to more deeply understand how port traffic influences important air pollutants. The estimates are significant and have a negative sign. This negative effect associated with $\mathrm{O}_{3}$ may be driven by increases in $\mathrm{NO}_{x}$ from port traffic (shown in Table 1), which can also interact with existing $\mathrm{O}_{3}$ in the air and in some cases actually reduce the total $\mathrm{O}_{3}$ concentrations (Sillman, 1999; Seinfeld and Pandis, 2016; He et al., 2020). ${ }^{35}$ In the remainder of the paper, we focus on the four criteria air pollutants $\left(\mathrm{CO}, \mathrm{NO}_{2}, \mathrm{PM}_{2.5}\right.$, and $\mathrm{SO}_{2}$ ), noting that they can all affect human health via channels separate from $\mathrm{O}_{3}$.

While there are no other estimates like ours in the literature, to our knowledge, the U.S. Environmental Protection Agency estimates that emissions associated with marine traffic account for $7-61 \%$ of $\mathrm{NO}_{\mathrm{x}}$ and $\mathrm{SO}_{\mathrm{x}}$ in certain port areas (EPA, 2003). In a rough calculation, our estimates suggest that marine shipping in the 27 major ports in the United States contributes $40 \%$ of air pollution within a 25-mile radius (see Appendix C.1).

We also estimate the model given in equation (1) using OLS for comparison purposes. These results using vessel tonnage as the covariate of interest are shown in Table A.13. The estimated coefficients are much smaller than those in Table 1, and not all are significant. The smaller values of these coefficients may be the result of attenuation bias due to

\footnotetext{
${ }^{34} \mathrm{NO}_{\mathrm{x}}$ is a generic term for chemical compounds of oxygen and nitrogen (i.e., mainly $\mathrm{NO}$ and $\mathrm{NO}_{2}$ ) that are related to the formation of smog, acid rain, and ozone. Similarly, $\mathrm{SO}_{\mathrm{x}}$ are chemical compounds of oxygen and sulfur, such as $\mathrm{SO}_{2}$.

${ }^{35}$ This finding is the opposite to Moretti and Neidell (2011), where port traffic results in an increase in $\mathrm{O}_{3}$ concentrations in the port areas of Los Angeles. This discrepancy may be due to different studied locations. Auffhammer and Kellogg (2011) show that southern California, including Los Angeles, tends to be VOC-limited for $\mathrm{O}_{3}$ formation (the opposite is $\mathrm{NO}_{x}$-limited), where the $\mathrm{NO}_{x}$ concentrations are relatively high, and increases in $\mathrm{NO}_{x}$ emissions may not change $\mathrm{O}_{3}$ concentrations. Our study covers a larger set of port locations that likely consists of both $\mathrm{NO}_{\mathrm{x}}$-limited and VOC-limited areas.
} 
measurement errors, which are exacerbated by our fixed effects (see Schlenker and Walker (2016) and Deryugina et al. (2019) for similar findings).

\subsection{Racial Disparities in the Effects of Air Pollution on Health}

We now turn to the effects of air pollution on health outcomes-and how they differ by race. We estimate the model given in equation (3) using two-stage least squares, where we instrument for air pollution using the fitted vessel tonnage and local wind conditions. ${ }^{36}$ We perform this estimation using the data from California to leverage our hospital admissions data. The standard errors for the health analysis are clustered by zip code-port and day.

Table 2 presents the results of the second stage of the instrumental variables estimation, showing the effect of increased air pollutant concentrations on hospital visits per million residents for respiratory, heart, and psychiatric problems. Panel A shows the results for the overall population within 25 miles of port facilities, while Panels B and C show the results for Blacks and whites, respectively. ${ }^{37}$ Each estimate represents an individual regression.

The results in Panel A show significant effects of all four pollutants we are studying on hospital visits for the overall population. For example, a one part per billion (ppb) increase in $\mathrm{CO}$ leads to an additional 0.05 visits for all respiratory illnesses, 0.01 visits for all heart-related diseases, and 0.01 visits related to all psychiatric conditions (per million residents per day). The effects of a one-unit increase in $\mathrm{SO}_{2}$ are substantial. There are apparent effects of $\mathrm{NO}_{2}$ and $\mathrm{PM}_{2.5}$ as well, but they are an order of magnitude smaller than $\mathrm{SO}_{2}$ (of course, the units are different). The results for psychiatric disorders are especially notable as there are no similar estimates in the literature. For respiratory and heart ailments, we find that our results are roughly in line with the literature, although somewhat smaller than some estimates and larger than others, depending on the exact health effect and pollutant (see Appendix C.1). This may not be surprising because we are focusing on the area around ports, which may be different than other areas. ${ }^{38}$

The results in Panels B and C of Table 2 show striking differences in hospital visits between Blacks and whites. The rate of hospital visits per million residents is more than double for Blacks than for whites in nearly all categories of pollutants we study. For

\footnotetext{
${ }^{36}$ We obtain fitted vessel tonnage from equation (5) using the full data sample for the 27 U.S. ports from 2001 to 2016.

${ }^{37}$ Tables A.14-A.16 also present more details behind the compiled Table 2, including adjusted $\mathrm{R}^{2}$ and the numbers of observations. Importantly, they show that we again have a strong first stage. For the pooled estimation, the first-stage F-statistics range from 28 to 79 . The first stage is also strong when we split the sample by race (Tables A.15 and A.16). In addition, the p-values from the Anderson-Rubin and Stock-Wright tests help us further rule out the presence of weak instruments.

${ }^{38}$ Table A.17 presents the OLS estimates for the same specifications. Some OLS estimates are insignificant, and nearly all OLS estimates have a smaller magnitude than their corresponding instrumented estimates.
} 
instance, there are only 18.3 visits related to respiratory illnesses per million residents due to a one-unit increase in $\mathrm{SO}_{2}$ exposure for whites, and 85.7 for Blacks. The rate of heart ailments is also higher for Blacks. While we showed an economically and statistically significant effect of air pollution on psychiatric-related hospital visits for the overall population nearby ports, the effects are not significant when using only the Black subsample, possibly due to the smaller sample size. On the white subsample, we observe significant results (at the $5 \%$ level) similar to those in the overall results for the all psychiatric category. ${ }^{39}$

While the focus of this paper is the racial gap between Blacks and whites, we also estimate the effects of air pollution on hospitalizations for Hispanics, which are shown in Figure A.19. When compared to the results in Table 2, Hispanics have higher hospitalization rates associated with respiratory ailments than whites but lower rates than Blacks. Hispanics have lower hospitalization rates associated with heart diseases than Blacks and whites. We also see more significant estimates associated with psychiatric illnesses for Hispanics. ${ }^{40}$

When interpreting these estimates, it is also important to keep in mind several crucial points. The estimated health effects may not be entirely attributable to a single pollutant since some pollutants may be co-emitted with others. In an extension, we also estimate the joint effects of certain pollutants on hospitalization rates, presented in the next subsection. Another crucial point is that some people who are ill may choose not to visit hospitals due to restricted access to medical resources or the opportunity costs of spending time in a hospital. These are common caveats in the literature using hospitalization data.

Another important point is that these estimates of health effects focus on the contemporaneous effects of air pollution on health. There may also be longer-term effects, including cumulative effects or symptoms that arise a few days later. Thus, we estimate our model using different time windows up to 28 days following a pollution exposure for the overall population, Blacks, and whites. ${ }^{41}$ Figures B.9-B.11 illustrate that the estimates gradually increase with the length of the time window for respiratory illnesses, suggesting cumulative health effects of air pollution. For psychiatric and heart illnesses, the effect of

\footnotetext{
${ }^{39}$ Table A.18 presents the estimation results using differences in hospitalization rates between Blacks and whites as the dependent variable. All estimates associated with respiratory ailments are positive and statistically significant. Most estimates associated with heart and psychiatric illnesses are not significant. In addition, Figure C.1 presents results using the recentered influence function approach pioneered by Firpo et al. (2009) and used recently by Currie et al. (2020). Appendix C.2 provides more details on this approach. We find that most air pollutants have a much larger impact on Blacks than whites at the upper quantiles of the hospitalization rate distribution, providing deeper insight into our primary results.

${ }^{40} \mathrm{We}$ also explore heterogeneous effects of air pollution by age and sex. Table A.20 shows that there are larger effects on children for respiratory illnesses and larger effects on the elderly for psychiatric and heart maladies. Table A.21 shows little difference in the effect between males and females.

${ }^{41}$ These estimations include the commensurate number of leading weather controls.
} 
air pollution appears to be flat and even decreasing for Blacks and whites after 21 days.

To provide further context, we calculate the effects of one additional average-tonnage vessel in a port over a year on air pollution-induced annual hospitalizations and hospital medical costs, as shown in Table 3.42 Panel A shows the results of annual hospitalizations for residents living within 25 miles of a major port facility. For Blacks, one additional vessel in port results in 2,400 respiratory hospital visits, 510 heart-related visits, and 130 psychiatric visits (per million residents in a year in California). This amounts to 3.0 additional hospital visits per thousand Black residents in a year. For whites, one additional vessel in port results in 520 respiratory hospital visits, 280 heart-related visits, and 230 psychiatric visits (per million residents in a year). This adds up to 1.0 additional hospital visits per thousand white residents in a year, only one-third of the visits for Black residents.

Panel B of Table 3 calculates the cost of these additional hospital visits. For this calculation, we use the 2017 inpatient discharge data from the Centers for Medicare and Medicaid Services (CMS). ${ }^{43}$ The results of the calculation show that one more average-tonnage vessel in port over a year leads to $\$ 27$ in medical costs per capita for Black residents and $\$ 10$ for white residents. ${ }^{44}$

These findings show clear racial disparities in the health effects of air pollution in port areas. A natural question that arises is whether these disparities are due to Blacks living in more polluted areas or Blacks having greater vulnerability to air pollution exposure (Hsiang et al., 2019). The evidence presented in Section 3.7 clearly shows that the Black population tends to live closer to ports and thus is highly likely to have greater exposure to pollution than the white population. In the population of hospital patients, Blacks are from zip codes that also face higher exposure. This underscores that differences in exposure are at least part of the story.

To explore whether Blacks have higher marginal damages in response to the same pollutant exposures than whites (i.e., are more vulnerable to exposure), we identify a set of

\footnotetext{
${ }^{42}$ We calculate the results in the following steps: (1) calculate pollution concentration changes for the studied pollutants due to one more vessel in ports (i.e., a $12.6 \%$ increase in vessel tonnage) based on the estimates in Panel A of Table 1; (2) calculate changes in annual hospital visits due to the changes in concentrations of $\mathrm{CO}, \mathrm{NO}_{2}, \mathrm{PM}_{2.5}$, and $\mathrm{SO}_{2}$ based on the estimates in Table 2; (3) select the largest values across the air pollutants for each illness category.

${ }^{43}$ The Medicare data provide national average inpatient payments and total discharges for each diagnosis, which is categorized by the MS-DRG code (see https:/ / www.cms.gov / Research-Statistics-Data-and-Systems / Statistics-Trends-and-Reports/Medicare-Provider-Charge-Data/Inpatient2017). We use the web service (http:/ /icd10cmcode.com) based on CMS's ICD-10 MS-DRG Conversion Project to convert the ICD-10 diagnosis codes to the MS-DRG codes. The mapped MS-DRG codes for the studied primary illness groups are presented in Table A.2. We calculate the average medical costs for each of the illness groups, weighted by the total number of discharges.

${ }^{44} \mathrm{We}$ also calculate the effects of one standard deviation increase in pollution concentrations on annual hospitalizations and medical costs. The results are presented in Table A.22.
} 
zip codes that have similar distances to ports and similar pollution levels. Some of these zip codes are predominantly Black, which we define as at least $50 \%$ Black, and others are over 50\% white. Specifically, we find zip codes that are 11-20 miles from ports and that have $11-12 \mu \mathrm{g} / \mathrm{m}^{3}$ annual $\mathrm{PM}_{2.5}$ concentrations based on the CalEnviroScreen data. Thus, we have zip codes with similar pollution exposure but different racial composition.

We then run the regressions in equations (3)-(5) for each of the two groups of zip codes. Figure 5 shows the results and illustrates that the four pollutants have larger significant effects on hospitalization rates related to respiratory, heart, and psychiatric for Blacks than whites. While we cannot entirely rule out differences of exposure to air pollution within zip codes, we see these results as highly suggestive that Blacks face higher marginal damages from air pollution exposure than whites even if exposure is held constant. This may be due to differences in baseline health, income, avoidance behavior, defensive investments, or other socioeconomic factors between the racial groups. We cannot distinguish between these explanations but view assessing these explanations as an important area for future work.

\subsection{Placebo Tests, Extensions, and Robustness Checks}

In this section, we conduct two placebo tests and a set of extensions and robustness checks to support our identification and highlight the channels driving our results.

Placebo Tests. In the first placebo test, we consider the possibility that lagged distant tropical cyclones might affect air pollution through channels other than port traffic that still have effects days later. Should this be the case, it would imply that our instrument directly affects air pollution through a channel outside of port traffic. To test this possibility, we examine air pollutant concentrations in areas far from ports (e.g., 75-100 miles) but similarly distant from the tropical cyclones as the ports. We regress air pollution concentrations in these "control" areas far from the ports on the lagged distant tropical cyclone instrument. Table 4 shows that the coefficients from this estimation are close to zero and are not significant for any of the pollutants, in clear contrast to our results in Table 1. This finding supports our argument that lagged distant tropical cyclones are unlikely to have a lingering effect on weather patterns and air pollution through channels other than port traffic.

In our second placebo test, we consider the possibility that some other factor relating to port traffic may be influencing hospital admissions besides air pollution. If this were the case, one would expect hospital admissions for other illnesses that are clearly unrelated to pollution exposure also to increase with port traffic. For example, arterial embolisms, external neck wounds, and appendicitis are all maladies that are highly unlikely to relate 
to air pollution exposure. Table A.23 estimates the same specifications for the overall population as in Panel A of Table 2 for these prognoses. ${ }^{45}$ All of the coefficients are small and not statistically significant. This result supports our contention that air pollution is actually the cause of the health impacts we estimate.

Extensions and Robustness Checks. Table A.24 presents a set of robustness checks that use slightly different model specifications of the effect of vessels in port on pollutant concentrations. Panels A-C show that temporal fixed effects and weather controls are important for identification. Panel D shows that the results with fewer weather controls are reasonably close to the primary specification, suggesting that the results are not very sensitive to the exact specification of weather controls. Panel E presents the results of pollution monitors within 12.5 miles of the major ports rather than 25 miles. Some point estimates become insignificant, likely due to the reduced sample size, but the results for $\mathrm{PM}_{2.5}$ and $\mathrm{SO}_{2}$ are reasonably close to the baseline estimates.

We also run robustness checks relating to the exact definition of our lagged distant tropical cyclone instrument. In the primary specification presented above, we used a dummy variable for the existence seven days prior of tropical cyclones that are at least 500 miles away from ports (and we exclude any observations where a cyclone is within 300 miles within a two-day window). Table A. 25 presents a variety of the robustness checks relating to the instrument. These include using an 800-mile threshold to exclude cyclone observations to further reduce the likelihood of tropical cyclones influencing air pollution directly, using different numbers of days for the lag instead of seven days, using multiple lags as instruments, using limited information maximum likelihood (LIML) to address any chance of a weak instrument, and using the count of cyclones rather than a dummy for the existence of tropical cyclones. The results are reasonably close to the primary results in Table 1 for all specifications. ${ }^{46}$

Another important analysis, which also sheds light on the drivers of our results, is to examine the joint effects of air pollutants on health outcomes. Our primary specifications examine each air pollutant separately, following the standard in the literature. However, air pollutants may be co-emitted and co-transported, so some of the coefficients for individual pollutants may include the effects of multiple pollutants. Identifying joint effects is often more challenging due to the need to instrument for more than one variable, but it is

${ }^{45}$ The estimations of Table A.23 use principal diagnoses in the OSHPD data set for the placebo illnesses to avoid including diagnoses that could be indirectly related to pollution exposure.

${ }^{46}$ In addition, we run a specification including all of the removed observations due to the tropical cyclones being close to the ports. Table A.26 shows that the estimates remain significant and are quite similar to our primary results. 
possible. Local wind can impact the spatial dispersion of pollutants differently, and higher wind speeds may even influence the need for ship engine thrust and the rate of pollutant emissions. Thus, wind direction and wind speed continue to be useful instruments, providing a sufficient number of instruments. We focus on the joint effects of $\mathrm{CO}, \mathrm{NO}_{2}$, and $\mathrm{SO}_{2}$ that are directly emitted from engine combustion in ports. Because $\mathrm{NO}_{2}$ and $\mathrm{SO}_{2}$ are precursors to $\mathrm{PM}_{2.5}$ with an conversion rate of several percent per hour (Luria et al., 2001; Lin and Cheng, 2007), it is difficult to differentiate the effects between $\mathrm{PM}_{2.5}, \mathrm{NO}_{2}$, and $\mathrm{SO}_{2}$ (Deryugina et al., 2019). We use the sample of zip code-port-days for estimations where measurements for $\mathrm{CO}, \mathrm{NO}_{2}$, and $\mathrm{SO}_{2}$ are all available.

Table A.27 presents the results of the joint estimations. ${ }^{47}$ For the joint effects of $\mathrm{CO}$ and $\mathrm{NO}_{2}$ on respiratory ailments (column (1)), the estimates associated with $\mathrm{CO}$ are significantly positive, and the estimates associated with $\mathrm{NO}_{2}$ are negative and insignificant for the overall population. The negative sign is consistent with findings on near-source atmospheric chemistry, indicating that an increase in $\mathrm{NO}_{2}$ may decrease $\mathrm{O}_{3}$ concentrations in certain settings (Sillman, 1999; Seinfeld and Pandis, 2016). It is also consistent with results in Schlenker and Walker (2016). The coefficients for whites mirror those for the entire population, while for Blacks we find a positive coefficient.

The coefficients on CO in column (2) of Table A.27 are significant for the overall population and the white subsample. For Blacks, $\mathrm{SO}_{2}$ appears to be the driver for health outcomes. Blacks tend to live closer to ports and thus are more likely to be exposed to emissions from fossil fuels with high sulfur content (Wan et al., 2016). We see similar results when examining the combination of $\mathrm{CO}, \mathrm{NO}_{2}$, and $\mathrm{SO}_{2}$ in column (3), with $\mathrm{SO}_{2}$ having the strongest effect of increasing hospitalizations, and with $\mathrm{NO}_{2}$ having a negative coefficient for all three groups (at the $1 \%$ significance level for the overall population and $10 \%$ significance level for Blacks and whites). The remaining columns show fewer significant results, but the explanations are likely similar. These results underscore the complexity of joint estimation of co-pollutants. ${ }^{48}$

In another robustness check, we explore whether additional road congestion due to more port activity may be causing some of our health effects findings rather than air pollution. When there are more vessels in ports and greater tonnage being transferred, one would expect there to be more truck traffic. Our primary findings include the effect of

\footnotetext{
${ }^{47}$ While some first-stage F statistics (i.e., the cluster-robust Kleibergen-Paap Wald F statistics) are below the threshold of ten, the Anderson-Rubin and Stock-Wright LM S statistics suggest that weak instruments should not be a concern. The standard Cragg-Donald Wald F statistics are also larger than ten (not reported). For joint estimations, we only report the results for the overall categories of respiratory, heart, and psychiatric illnesses.

${ }^{48} \mathrm{We}$ also jointly estimate the model only using zip codes closer to ports, finding mostly larger estimates (see columns (1) and (3) in Table A.28).
} 
additional air pollution from increased truck traffic. Still, one might be concerned that some of the estimates-such as those relating to mental health-could be influenced by additional road congestion. Thus, we bring in vehicle detection data from the California Department of Transportation Performance Measurement System, which contains daily highway traffic data at the 'vehicle detection station' level for 2010-2016. ${ }^{49}$ For each hour of the day, these data include average daily delays (measured in vehicle hours spent to pass a freeway segment) at various threshold speeds (i.e., 35, 40, 45, 50, 55, and 60 miles per hour) for each station.

Our analysis selects all of the stations located within 10 miles of the six major ports in California, and we include the station-days with at least $40 \%$ of observations. We then regress traffic delay measures at the various threshold speeds on the fitted vessel tonnage or the fitted vessel count. Table A.29 presents these results, which show no significant coefficients across panels and columns, despite very large samples. We take this as suggestive evidence that our instrument-vessels in ports predicted by distant and lagged cyclones-is unlikely to substantially influence road congestion, indicating that air pollution is much more likely to be the channel through which our results occur.

We also consider whether wind may affect hospitalizations through factors other than air pollution. Strong winds may lead to fewer outdoor activities, thus reducing exposure to air pollutants. We run a robustness check excluding days with wind speeds greater than 3.3 meters per second, with this threshold chosen because it is the upper end of the "light breeze" designation under the Beaufort Wind Scale. The results are reasonably robust to the exclusion of intense windy days (see Table A.30).

Finally, we run a set of further robustness checks. We calculate hospitalization rates based only on principal diagnoses rather than the combination of principal and secondary diagnoses. The results (Table A.31) are similar to our baseline results, although the effects are a bit smaller. We estimate the model separately for each of the three hospitalization data sets we pool for our health results. Tables A.32-A.34 illustrate that we still find significant health effects (and racial disparities) from air pollution, and emergency room visits logged in the Emergency Department Data seem the main driver, although again the effects are smaller, as would be expected. We run our primary specification using LIML instead of two-stage least squares (Table A.35) and again find very similar results.

\footnotetext{
${ }^{49}$ The data are obtained from http:/ / pems.dot.ca.gov.
} 


\section{Policy Implications}

Our results showing racial disparities in the effects of port pollution on health outcomes raise the question of whether policy can help alleviate the disparities. Policy could directly reduce exposures by cutting emissions or address the drivers of the racial gap in the air pollution response functions. However, the latter is more difficult because of our limited knowledge of the explanations for the different response functions across races. Thus, policy has largely focused on reducing exposures. One example is a regulation in California to reduce emissions from port facilities by reducing fossil fuel usage in ports, perhaps most importantly by electrifying major port activities. We first employ a regression discontinuity design (RDD) to find the causal effect of the policy. Then we use dynamic simulation to explore whether generating additional electricity to power docked ships produces sufficient emissions to offset the health improvements from reduced ship emissions.

\subsection{Brief Background on Port-related Policies}

To date, several policies have been implemented to regulate emissions from marine ships. Perhaps the most prominent policy, the MARPOL Annex VI Protocol by International Maritime Organization, adopted in 1997, regulates sulfur content in marine fossil fuels to limit emissions of $\mathrm{NO}_{x}, \mathrm{SO}_{x}, \mathrm{PM}$, and VOCs in the ocean. ${ }^{50}$ More recently, attention has turned to replace fossil fuels altogether by electrifying port activities. This could include allowing docked vessels to turn off their auxiliary electricity-generating engines and instead use onshore electricity from the grid. Other port activities could also be electrified. ${ }^{51}$

California has the strongest regulations on port emissions in the United States. The centerpiece policy is the "Ocean-Going Vessel At-Berth Regulation," which was adopted in December 2007. This regulation limited air pollutant emissions from container ships, passenger ships, and refrigerated cargo ships at the six major California ports. ${ }^{52}$ There are two compliance options: use onshore electricity when docked or find an equivalent emission reduction through alternative fuels or emission control equipment. Beginning on January 1, 2010, vessel operators were required to reduce at-berth emissions of $\mathrm{NO}_{\mathrm{x}}$ and PM by 10\%, and since then the policy has been tightened further. ${ }^{53}$ Our analysis focuses

\footnotetext{
${ }^{50}$ See http:/ / www.imo.org/en/OurWork/Environment/PollutionPrevention/AirPollution/Pages / AirPollution.aspx.

${ }^{51}$ At the national level, United States has implemented several programs to reduce emissions from port facilities, including the Ports Initiative, EPA's Diesel Emissions Reduction Act (DERA) grant program, Department of Transportation's Transportation Investment Generating Economic Recovery (TIGER) and Congestion Mitigation and Air Quality Improvement (CMAQ) programs, and the Department of Energy's Clean Cities program (EPA, 2016).

${ }^{52}$ See https://ww2.arb.ca.gov/resources/documents/berth-faqs.

${ }^{53}$ For instance, beginning on January 12014 , at least 50\% of a fleet's visits must use onshore electricity each
} 
on the first phase of the regulation beginning on January 1, 2010.

\subsection{Effect of California's Regulation on Air Pollutant Concentrations}

Empirical Strategy. Our empirical strategy relies on the sharp discontinuity in how port activities were fueled on January 1, 2010. Onshore electricity and cleaner fossil fuels are more expensive than conventional fuels, and thus there was no incentive for ship operators and port operators to comply before this date (EPA, 2017). It is likely that some of the at-berth charging infrastructure was already installed prior to this date, but it was not being used.

Our regression discontinuity design follows a model specification similar in principle to several recent studies (e.g., Davis, 2008; Auffhammer and Kellogg, 2011; Chen and Whalley, 2012; Anderson, 2014; Bento et al., 2014):

$$
P_{i p t}=\rho \text { Policy }_{t}+f\left(\text { Date }_{t}\right)+\beta V_{p t}+\mathbf{W}_{i t} \theta+\delta_{t}+\mu_{i p}+e_{i p t} .
$$

The dependent variable $P_{\text {ipt }}$ is the log of the concentration of a local air pollutant in monitor $i$ that is mapped to port $p$ on day $t$. Polic $y_{t}$ is a dummy variable that is equal to one when the policy is in effect on day $t$ and zero otherwise. The expression $f\left(\right.$ Date $\left._{t}\right)$ is a flexible function of the date. The dates are normalized to be zero at the first date of the policy; hence, the coefficient $\rho$ represents the treatment effect of the policy. The variable $V_{p t}$ is the log vessel tonnage in port instrumented using our lagged distant tropical cyclones instrument. ${ }^{54}$ We include this variable for good measure, as this avoidance response may be somewhat unlikely given the evidence in Figure B.12, which shows that the number of vessels visiting the six major California ports exhibits no drastic changes before and after the policy. We also include the same weather controls $\left(\mathbf{W}_{i t}\right)$ and fixed effects $\left(\delta_{t}\right.$ and $\left.\mu_{i p}\right)$ as in equation (1).

The flexible function of the date is crucial for identification, as it controls for potential endogeneity from time as the running variable (Imbens and Lemieux, 2008). We specify $f\left(\right.$ Date $\left._{t}\right)$ with two terms: Date $e_{t}$ and Policy $y_{t} \times$ Date $_{t}$. Thus, our final specification is a local linear regression discontinuity design, following Imbens and Lemieux (2008):

$$
P_{i p t}=\rho \text { Polic }_{t}+\eta_{1} \text { Date }_{t}+\eta_{2} \text { Polic }_{t} \times \text { Date }_{t}+\beta V_{p t}+\mathbf{W}_{i t} \theta+\delta_{t}+\mu_{i p}+e_{i p t} .
$$

quarter of a year and auxiliary engine power generation must be reduced by $50 \%$.

${ }^{54} \mathrm{We}$ include the instrumented vessel tonnage because it controls for possible abrupt changes in the number of vessels visiting ports that might occur if there is an avoidance response of vessels to the policy implementation (Klotz and Berazneva, 2021). 
We estimate this equation using an augmented local linear approach to increase the power of estimation (Hausman and Rapson, 2018). The approach consists of two steps. We first use the full data sample to regress log pollution measures on the exogenous variables (e.g., weather controls, instrumented log vessel tonnage, and fixed effects). We then regress the residuals obtained from the first step on the regression discontinuity terms (i.e., Policy , Date $_{t}$, and Policy $\times$ Date $e_{t}$ ) within a narrow bandwidth of dates. We choose a bandwidth of 65 days on each side of the policy threshold in the primary specification and run robustness checks with different bandwidths.

Results. Following the augmented local linear approach, we first obtain the residuals by regressing air pollution concentrations on all exogenous regressors specified in equation (7) using the full data sample (2001-2016) across the six major California ports. Figure 6 plots daily average residuals for $\mathrm{NO}_{2}$ with a shorter time window around the first policy date (normalized to be zero). Each point is an average of residuals across all monitor-port pairs. We see clear downward breaks of linear trends occurring at the first date of the California at-berth regulation, suggesting that the regulation results in lower concentrations of $\mathrm{NO}_{2}$ in port areas (we observe similar declines for most other pollutants but without statistical significance).

Table 5 presents the regression results, where each column reports results from a separate regression for a pollutant. The estimates in the first row indicate the effect of the regulation. Consistent with Figure 6, the coefficient for $\mathrm{NO}_{2}$ is significant at the $5 \%$ level, as shown in columns (2). The regulation leads to a decrease in average pollution concentrations by $20 \%$ for $\mathrm{NO}_{2}$. There also appear to be reductions in $\mathrm{CO}$ emissions, but the coefficient is not significant at the $5 \%$ level..$^{55}$

We next calculate the avoided annual hospital visits and hospital-related medical costs per capita by race due to the California regulation. ${ }^{56}$ Table 6 shows that the regulation results in 9.9 avoided hospital visits per thousand Black residents per year associated with psychiatric, respiratory, and heart-related illnesses. It also leads to 3.4 avoided hospital visits per thousand white residents per year. The avoided medical costs per capita per year

\footnotetext{
${ }^{55}$ We conduct bootstrap inference to test the estimates associated with the policy variable, following the fast wild cluster bootstrap algorithm in Roodman et al. (2019). For each regression, we obtain 10,000 bootstrap draws with replacement clustered by monitor-port and day, which is comparable to the primary specification with clustering by monitor-port and day. Figure B.13 presents the bootstrap 95\% confidence intervals, which are fairly close to the primary specification results.

${ }^{56}$ We calculate the results with the following steps: (1) calculate absolute pollution concentration changes based on the estimates in Table 5; (2) calculate changes in annual hospital visits due to the changes in CO, $\mathrm{NO}_{2}, \mathrm{PM}_{2.5}$, and $\mathrm{SO}_{2}$ concentrations based on the estimates in Table 2; (3) for each illness category, select the largest values across the air pollutants (to avoid double-counting due to the possibility of joint emissions). Note that these results do not account for any increases in emissions from the power sector.
} 
for Black residents come out to $\$ 88$, which is much larger than the $\$ 31$ for whites. These results highlight how the policy alleviated the Black-white gaps in air pollution-induced hospitalizations around ports.

Simple calculations suggest that the benefits of avoiding adverse health outcomes from this policy outweigh the costs. The California Air Resources Board estimates that the annual regulatory costs for affected businesses and port authorities due to the Ocean-Going Vessel At-Berth Regulation vary from \$36 million to \$167 million in 2017 USD. ${ }^{57}$ Our estimates suggest that the first phase of the regulation leads to a saving of $\$ 558$ million in medical costs per year. ${ }^{58}$

We also run two placebo tests for the RDD analysis. The first test moves the discontinuity from the actual date of policy implementation to a different date: either January 1, 2009, or January 1, 2011. If seasonal effects drive our results, the coefficients would be similar to our primary results. The second placebo test examines regions further away from the ports to confirm that something else statewide was not affecting air pollution on January 1 , 2010. We use the data from air pollution monitors 75-100 miles from the California ports. Table A.36 shows the results of these placebo tests. The coefficients tend to be insignificant and generally close to zero, providing further evidence supporting our identification.

The results from varying the bandwidth are shown in Figure B.14, and indicate that the exact choice of bandwidth makes little difference to our estimates. We also specify a 'donut' model in which a certain number of days are removed on either side of the policy threshold (Barreca et al., 2011). This specification addresses a potential concern about short-term avoidance behaviors by vessels in response to the policy (Hausman and Rapson, 2018). Figure B.15 presents the results with various donut periods, showing that the results do not deviate substantially from our primary estimates.

\subsection{Dynamic Simulation}

If the California regulation reduced fossil fuel use in ports but increased fossil fuel use from electricity generation, it is possible that the pollution was just shifted from one place to another. To explore this possibility, we use a dynamic simulation of the entire energy system in the United States. Specifically, we implement a reference case scenario based on the U.S. Energy Information Administration (EIA) Annual Energy Outlook and a scenario that gradually shifts at-berth energy consumption from fossil fuel-powered

\footnotetext{
${ }^{57}$ See https://ww3.arb.ca.gov/regact/2007/shorepwr07/tsd.pdf.

${ }^{58}$ Table 6 presents that the California at-berth regulation results in $\$ 37$ savings per capita for illnesses related to respiratory, heart, and psychiatric illnesses. There are 15.08 million residents living within 25 miles of the major ports in California. The medical costs of $\$ 558$ million are the multiplication of $\$ 37$ and 15.08 million.
} 
auxiliary engines to electricity across all ports in the United States. Then we examined how electricity generation and emissions change.

To perform this exercise, we use the National Energy Modeling System (NEMS) run on a Yale server. ${ }^{59}$ This model is a general equilibrium model that includes all major energy markets and explicitly depicts major energy supply sectors (coal, natural gas, oil), demand sectors (residential, industrial, commercial, and transportation), conversion sectors (electricity and liquid fuels), macroeconomic activities, and international energy markets (EIA, 2009). It has an electricity dispatch model with geographic disaggregation based on the actual fleet of generating plants in the United States. Besides producing well-respected government forecasts, it has been used for decades by researchers to analyze energy market transitions and policies (e.g., Palmer et al., 2010; Auffhammer and Sanstad, 2011; Wilkerson et al., 2013; Gillingham and Huang, 2019, 2020). It is especially useful for our research question in that it contains a detailed link between energy consumption in ports and electricity generation. Appendix D contains more details on the model and the two scenarios.

Figure B.16 presents the simulation modeling results for $\mathrm{CO}, \mathrm{NO}_{\mathrm{x}}, \mathrm{PM}_{2.5}$, and $\mathrm{SO}_{2}$ emissions from vessels and electricity generation in the United States for the reference case and the policy scenario. ${ }^{60}$ Notably, the reduction in emissions from marine vessels is substantial and notable, while the increase in emissions from electricity generation is extremely small. The reason for this result is simple: the power sector uses much cleaner energy sources on average (i.e., natural gas and renewables) and is adopting technologies to mitigate emissions over time. Line losses are modeled and make a negligible impact. While every simulation model should be viewed as an informed approximation and should not be taken as a causal estimate, this finding from the simulation modeling suggests that the localized air pollution benefits from a policy to reduce emissions from port activities are very likely to outweigh any negative effects of additional air pollution from increased electricity generation. The result is likely to be even stronger in California, which has an especially clean electricity grid.

\section{Conclusions}

This paper establishes a set of causal relationships from port traffic to air pollution and racial disparities in health outcomes. We use a quasi-experiment, where port traffic

\footnotetext{
${ }^{59}$ The model we use is identical to EIA's NEMS with minor configuration adjustments to enable us to run it on a Yale server.

${ }^{60}$ Table A.37 presents the associated fossil fuel and electricity consumptions by marine vessels across the scenarios.
} 
is influenced by lagged distant tropical cyclones, to ascertain the effect of port traffic on local air pollution and hospitalizations. To the best of our knowledge, we are the first to investigate how a very highly emitting point source-port facilities—can influence racial disparities in health and how policy can bring about distributional consequences.

Our results show that adding another vessel or increasing the overall vessel tonnage in ports will increase air pollution concentrations in the areas surrounding the ports. This leads to increased hospitalizations for respiratory, heart-related, and psychiatric ailments that disproportionately affect Black residents. One additional vessel in port over a year leads to 3.0 additional hospital visits per thousand Black residents per year and 1.0 visits per thousand whites. We provide evidence that the two racial groups are receiving different pollution exposures and may have differing response functions. Policy to reduce emissions from ships at berth may help reduce the disparities, and we show that a major California regulation disproportionately benefits Black residents. This California regulation reduces hospital visits by 9.9 per thousand Blacks per year and 3.4 per thousand whites.

The findings of this study lay the groundwork for further research uncovering racial disparities in air pollution in a variety of settings with highly polluting point sources, informing discussions about environmental justice, and providing guidance to policymakers aiming to improve public health and reduce inequality.

\section{References}

Agrawal, H., Eden, R., Zhang, X., Fine, P. M., Katzenstein, A., Miller, J. W., Ospital, J., Teffera, S., and Cocker, D. R. (2009). Primary particulate matter from ocean-going engines in the Southern California Air Basin. Environmental Science \& Technology, 43(14):5398-5402.

Alexander, D. and Currie, J. (2017). Is it who you are or where you live? Residential segregation and racial gaps in childhood asthma. Journal of Health Economics, 55:186-200.

Alexander, D. and Schwandt, H. (2019). The Impact of Car Pollution on Infant and Child Health: Evidence from Emissions Cheating.

Anderson, M. L. (2014). Subways, strikes, and slowdowns: The impact of public transit on traffic congestion. American Economic Review, 104(9):2763-2796.

Anderson, M. L. (2020). As the Wind Blows: The Effects of Long-Term Exposure to Air Pollution on Mortality. Journal of the European Economic Association, 18(4):1886-1927.

Andrews, I., Stock, J. H., and Sun, L. (2019). Weak Instruments in Instrumental Variables Regression: Theory and Practice. Annual Review of Economics, 11(1):727-753. 
Anglin, R. E., Samaan, Z., Walter, S. D., and Sarah, D. M. (2013). Vitamin D deficiency and depression in adults: Systematic review and meta-analysis. British Journal of Psychiatry, 202(2):100-107.

Arceo, E., Hanna, R., and Oliva, P. (2016). Does the Effect of Pollution on Infant Mortality Differ Between Developing and Developed Countries? Evidence from Mexico City. The Economic Journal, 126(591):257-280.

Auffhammer, M. and Kellogg, R. (2011). Clearing the air? the effects of gasoline content regulation on air quality. American Economic Review, 101(6):2687-2722.

Auffhammer, M. and Sanstad, A. H. (2011). Energy efficiency in the residential and commercial sectors. RFF Backgrounder.

Banzhaf, H. S., Ma, L., and Timmins, C. (2019a). Environmental Justice: Establishing Causal Relationships. Annual Review of Resource Economics, 11:377-398.

Banzhaf, H. S., Ma, L., and Timmins, C. (2019b). Environmental justice: The economics of race, place, and pollution. Journal of Economic Perspectives, 33(1):185-208.

Barreca, A. I., Guldi, M., Lindo, J. M., and Waddell, G. R. (2011). Saving babies? Revisiting the effect of very low birth weight classification. Quarterly Journal of Economics, 126(4):21172123.

Bell, M. L., Ebisu, K., Peng, R. D., Walker, J., Samet, J. M., Zeger, S. L., and Dominici, F. (2008). Seasonal and regional short-term effects of fine particles on hospital admissions in 202 US counties, 1999-2005. American Journal of Epidemiology, 168(11):1301-10.

Bento, A. M., Kaffine, D. T., Roth, K., and Zaragoza-Watkins, M. (2014). The effects of regulation in the presence of multiple unpriced externalities: Evidence from the transportation sector. American Economic Journal: Economic Policy, 6(3):1-29.

Bishop, K., Ketcham, J., and Kuminoff, N. (2018). Hazed and Confused: The Effect of Air Pollution on Dementia.

Bondy, M., Roth, S., and Sager, L. (2020). Crime Is in the Air: The Contemporaneous Relationship between Air Pollution and Crime. Journal of the Association of Environmental and Resource Economists, 7(3):555-585.

Borgschulte, M., Molitor, D., and Zou, E. Y. (2018). Air Pollution and the Labor Market: Evidence from Wildfire Smoke. 
Boustan, L., Margo, R. A., Boustan, L., and Margo, R. A. (2016). Racial Differences in Health in the United States. In The Oxford Handbook of Economics and Human Biology, pages 729-750. Oxford University Press.

Boustan, L. P. (2012). Racial Residential Segregation in American Cities. In The Oxford Handbook of Urban Economics and Planning. Oxford University Press.

Brokamp, C., Strawn, J. R., Beck, A. F., and Ryan, P. (2019). Pediatric Psychiatric Emergency Department Utilization and Fine Particulate Matter: A Case-Crossover Study. Environmental Health Perspectives, 127(9):097006.

Burkhardt, J., Bayham, J., Wilson, A., Carter, E., Berman, J. D., O’Dell, K., Ford, B., Fischer, E. V., and Pierce, J. R. (2019). The effect of pollution on crime: Evidence from data on particulate matter and ozone. Journal of Environmental Economics and Management, 98:102267.

Chaloulakou, A., Kassomenos, P., Spyrellis, N., Demokritou, P., and Koutrakis, P. (2003). Measurements of PM10 and PM2.5 particle concentrations in Athens, Greece. Atmospheric Environment, 37(5):649-660.

Chang, T. Y., Graff Zivin, J., Gross, T., and Neidell, M. (2016). Particulate pollution and the productivity of pear packers. American Economic Journal: Economic Policy, 8(3):141-169.

Chang, T. Y., Graff Zivin, J., Gross, T., and Neidell, M. (2019). The Effect of Pollution on Worker Productivity: Evidence from Call Center Workers in China. American Economic Journal: Applied Economics, 11(1):151-172.

Chay, K. Y. and Greenstone, M. (2003a). Air Quality, Infant Mortality, and the Clean Air Act of 1970.

Chay, K. Y. and Greenstone, M. (2003b). The impact of air pollution on infant mortality: evidence from geographic variation in pollution shocks induced by a recession. Quarterly Journal of Economics, 118(3):1121-1167.

Chen, S., Oliva, P., and Zhang, P. (2018). Air Pollution and Mental Health: Evidence from China.

Chen, Y. and Whalley, A. (2012). Green infrastructure: The effects of urban rail transit on air quality. American Economic Journal: Economic Policy, 4(1):58-97. 
Cheng, I., Tseng, C., Wu, J., Yang, J., Conroy, S. M., Shariff-Marco, S., Li, L., Hertz, A., Gomez, S. L., Le Marchand, L., Whittemore, A. S., Stram, D. O., Ritz, B., and Wu, A. H. (2020). Association between ambient air pollution and breast cancer risk: The multiethnic cohort study. International Journal of Cancer, 146(3):699-711.

Cohen-Cline, H., Turkheimer, E., and Duncan, G. E. (2015). Access to green space, physical activity and mental health: A twin study. Journal of Epidemiology and Community Health, 69(6):523-529.

Colmer, J., Hardman, I., Shimshack, J. P., and Voorheis, J. (2020). Disparities in PM 2.5 air pollution in the United States. Science, 369(6503):575-578.

Cragg, J. G. and Donald, S. G. (1993). Testing Identifiability and Specification in Instrumental Variable Models. Econometric Theory, 9(2):222-240.

Currie, J. (2011). Inequalities at birth: Some causes and consequences. American Economic Review: Papers \& Proceedings, 101(3):1-22.

Currie, J., Greenstone, M., and Meckel, K. (2017). Hydraulic fracturing and infant health: New evidence from Pennsylvania. Science Advances, 3(12):e1603021.

Currie, J. and Neidell, M. (2005). Air pollution and infant health: What can we learn from Claifornia's recent experience. Quarterly Journal of Economics, 120(3):1003-1030.

Currie, J., Neidell, M., and Schmieder, J. F. (2009). Air pollution and infant health: Lessons from New Jersey. Journal of Health Economics, 28(3):688-703.

Currie, J., Voorheis, J., and Walker, W. R. (2020). What Caused Racial Disparities in Particulate Exposure to Fall? New Evidence from the Clean Air Act and Satellite-Based Measures of Air Quality.

Currie, J. and Walker, W. R. (2011). Traffic congestion and infant health: Evidence from E-Zpass. American Economic Journal: Applied Economics, 3(1):65-90.

Dahl, G. B. and Lochner, L. (2012). The Impact of Family Income on Child Achievement: Evidence from the Earned Income. American Economic Review, 102(5):1927-1956.

Davis, L. W. (2008). The effect of driving restrictions on air quality in Mexico City. Journal of Political Economy, 116(1):38-81.

Davis, L. W. (2011). The Effect of Power Plants on Local Housing Values and Rents. Review of Economics and Statistics, 93(4):1391-1402. 
Deryugina, T., Heutel, G., Miller, N. H., Molitor, D., and Reif, J. (2019). The Mortality and Medical Costs of Air Pollution: Evidence from Changes in Wind Direction. American Economic Review, 109(12):4178-4219.

Deschênes, O., Greenstone, M., and Shapiro, J. S. (2017). Defensive Investments and the Demand for Air Quality: Evidence from the NOx Budget Program. American Economic Review, 107(10):2958-2989.

DeVries, R., Kriebel, D., and Sama, S. (2017). Outdoor Air Pollution and COPD-Related Emergency Department Visits, Hospital Admissions, and Mortality: A Meta-Analysis. COPD: Journal of Chronic Obstructive Pulmonary Disease, 14(1):113-121.

Dockery, D. W. and Pope III, C. A. (1994). Acute Respiratory Effects of Particulate Air Pollution. Annual Review of Public Health, 15(1):107-132.

Dockery, D. W., Pope III, C. A., Xu, X., Spengler, J. D., Ware, J. H., Fay, M. E., Ferris, B. G., and Speizer, F. E. (1993). An Association between Air Pollution and Mortality in Six U.S. Cities. New England Journal of Medicine, 329(24):1753-1759.

Dominici, F., Peng, R. D., Bell, M. L., Pham, L., McDermott, A., Zeger, S. L., and Samet, J. M. (2006). Fine particulate air pollution and hospital admission for cardiovascular and respiratory diseases. JAMA, 295(10):1127-34.

Ebenstein, A., Lavy, V., and Roth, S. (2016). The Long-Run Economic Consequences of High-Stakes Examinations: Evidence from Transitory Variation in Pollution. American Economic Journal: Applied Economics, 8(4):36-65.

EIA (2009). The National Energy Modeling System: An Overview 2009. Technical report, United State Energy Information Administration, Washington, DC.

EPA (2003). Control of Emissions From New Marine Compression-Ignition Engines at or Above 30 Liters Per Cylinder. Technical report, United States Environmental Protection Agency, Washington, DC.

EPA (2016). National Port Strategy Assessment: Reducing Air Pollution and Greenhouse Gses at U.S. Ports. Technical report, Office of Transportation Air Quality, EPA, Washington, DC.

EPA (2017). Shore Power Technology Assessment at U.S. Ports. Technical report, Offce of Transportation and Air Quality, EPA, Washington, DC. 
Firpo, S., Fortin, N. M., and Lemieux, T. (2009). Unconditional Quantile Regressions. Econometrica, 77(3):953-973.

George, L. K., Blazer, D. G., Hughes, D. C., and Fowler, N. (1989). Social support and the outcome of major depression. British Journal of Psychiatry, 154(APR.):478-485.

Gillingham, K. and Huang, P. (2019). Is abundant natural gas a bridge to a low-carbon future or a dead-end? Energy Journal, 40(2):1-26.

Gillingham, K. and Huang, P. (2020). Long-Run Environmental and Economic Impacts of Electrifying Waterborne Shipping in the United States. Environmental Science \& Technology, 54(16):9824-9833.

Graff Zivin, J. and Neidell, M. (2012). The Impact of Pollution on Worker Productivity. American Economic Review, 102(7):3652-3673.

Graff Zivin, J. and Neidell, M. (2013). Environment, Health, and Human Capital. Journal of Economic Literature, 51(3):689-730.

Halliday, T. J., Lynham, J., and De Paula, A. (2019). Vog: Using Volcanic Eruptions to Estimate the Health Costs of Particulates. Economic Journal, 129(620):1782-1816.

Hanna, R. and Oliva, P. (2015). The effect of pollution on labor supply: Evidence from a natural experiment in Mexico City. Journal of Public Economics, 122:68-79.

Hausman, C. and Rapson, D. S. (2018). Regression discontinuity in time: Considerations for empirical applications. Annual Review of Resource Economics, 10(1).

He, G., Pan, Y., and Tanaka, T. (2020). The short-term impacts of COVID-19 lockdown on urban air pollution in China. Nature Sustainability, 3(12):1005-1011.

Herrnstadt, E., Heyes, A., Muehlegger, E., and Saberian, S. (2021). Air Pollution and Criminal Activity: Microgeographic Evidence from Chicago. American Economic Journal: Applied Economics.

Houston, D., Krudysz, M., and Winer, A. (2008). Diesel Truck Traffic in Low-Income and Minority Communities Adjacent to Ports: Environmental Justice Implications of NearRoadway Land Use Conflicts. Transportation Research Record: Journal of the Transportation Research Board, 2067(1):38-46. 
Houston, D., Li, W., and Wu, J. (2014). Disparities in exposure to automobile and truck traffic and vehicle emissions near the Los Angeles-long beach port complex. American Journal of Public Health, 104(1):156-164.

Hsiang, S., Oliva, P., and Walker, W. R. (2019). The Distribution of Environmental Damages. Review of Environmental Economics and Policy, 13(1):83-103.

Imbens, G. W. and Lemieux, T. (2008). Regression discontinuity designs: A guide to practice. Journal of Econometrics, 142(2):615-635.

Karner, A. A., Eisinger, D. S., and Niemeier, D. A. (2010). Near-roadway air quality: Synthesizing the findings from real-world data. Environmental Science \& Technology, 44(14):5334-5344.

Keiser, D. A., Lade, G. E., and Rudik, I. (2018). Air pollution and visitation at U.S. national parks. Science Advances, 4(7).

Keller, J. P., Larson, T. V., Austin, E., Barr, R. G., Sheppard, L. E., Vedal, S., Kaufman, J. D., and Szpiro, A. A. (2018). Pollutant composition modification of the effect of air pollution on progression of coronary artery calcium. Environmental Epidemiology, 2(3):e024.

Kim, S. H., Shin, S. D., Song, K. J., Ro, Y. S., Kong, S. Y., Kim, J., Ko, S. Y., and Lee, S. Y. (2018). Association between ambient PM2.5 and emergency department visits for psychiatric emergency diseases. American Journal of Emergency Medicine.

Kleibergen, F. and Paap, R. (2006). Generalized reduced rank tests using the singular value decomposition. Journal of Econometrics, 133(1):97-126.

Klotz, R. and Berazneva, J. (2021). Correlated Pollutants, Avoidance, and Local Environmental Policy.

Knittel, C. R., Miller, D. L., and Sanders, N. J. (2016). Caution, drivers! children present: Traffic, pollution, and infant health. Review of Economics and Statistics, 98(2):350-366.

Kukkonen, J., Pohjola, M., Sokhi, R. S., Luhana, L., Kitwiroon, N., Fragkou, L., Rantamäki, M., Berge, E., Ødegaard, V., Slørdal, L. H., Denby, B., and Finardi, S. (2005). Analysis and evaluation of selected local-scale PM10 air pollution episodes in four European cities: Helsinki, London, Milan and Oslo. Atmospheric Environment, 39:2759-2773.

Liebler, C. A., Porter, S. R., Fernandez, L. E., Noon, J. M., and Ennis, S. R. (2017). America's Churning Races: Race and Ethnicity Response Changes Between Census 2000 and the 2010 Census. Demography, 54(1):259-284. 
Lin, Y. C. and Cheng, M. T. (2007). Evaluation of formation rates of NO2 to gaseous and particulate nitrate in the urban atmosphere. Atmospheric Environment, 41(9):1903-1910.

Luria, M., Imhoff, R. E., Valente, R. J., Parkhurst, W. J., and Tanner, R. L. (2001). Rates of conversion of sulfur dioxide to sulfate in a scrubbed power plant plume. Journal of the Air \& Waste Management Association, 51(10):1408-13.

Moeltner, K., Kim, M. K., Zhu, E., and Yang, W. (2013). Wildfire smoke and health impacts: A closer look at fire attributes and their marginal effects. Journal of Environmental Economics and Management, 66(3):476-496.

Mohai, P., Pellow, D., and Roberts, J. T. (2009). Environmental justice. Annual Review of Environment and Resources, 34:405-430.

Moretti, E. and Neidell, M. (2011). Pollution, health, and avoidance behavior: evidence from the Ports of Los Angeles. Journal of Human Resources, 46(1):154-175.

Ordonez, P. (2020). Power Plants, Air Pollution, and Health in Colombia.

Palmer, K. L., Sweeney, R., and Allaire, M. (2010). Modeling policies to promote renewable and low-carbon sources of electricity.

Riggs, D. W., Zafar, N., Krishnasamy, S., Yeager, R., Rai, S. N., Bhatnagar, A., and O'Toole, T. E. (2020). Exposure to airborne fine particulate matter is associated with impaired endothelial function and biomarkers of oxidative stress and inflammation. Environmental Research, 180.

Roodman, D., Nielsen, M. Ø., MacKinnon, J. G., and Webb, M. D. (2019). Fast and wild: Bootstrap inference in Stata using boottest. The Stata Journal, 19(1):4-60.

Sager, L. (2019). Estimating the effect of air pollution on road safety using atmospheric temperature inversions. Journal of Environmental Economics and Management, 98:102250.

Salim, S., Asghar, M., Taneja, M., Hovatta, I., Chugh, G., Vollert, C., and Vu, A. (2011). Potential contribution of oxidative stress and inflammation to anxiety and hypertension. Brain Research, 1404:63-71.

Sanders, N. J. (2012). What Doesn't Kill You Makes You Weaker: Prenatal Pollution Exposure and Educational Outcomes. Journal of Human Resources, 47(3):826-850.

Sanders, N. J. and Stoecker, C. (2015). Where have all the young men gone? Using sex ratios to measure fetal death rates. Journal of Health Economics, 41:30-45. 
Sass, V., Kravitz-Wirtz, N., Karceski, S. M., Hajat, A., Crowder, K., and Takeuchi, D. (2017). The effects of air pollution on individual psychological distress. Health \& Place, 48:72-79.

Schlenker, W. and Walker, W. R. (2016). Airports, air pollution, and contemporaneous health. Review of Economic Studies, 83(2):768-809.

Scott, K. M., Von Korff, M., Ormel, J., Zhang, M. y., Bruffaerts, R., Alonso, J., Kessler, R. C., Tachimori, H., Karam, E., Levinson, D., Bromet, E. J., Posada-Villa, J., Gasquet, I., Angermeyer, M. C., Borges, G., de Girolamo, G., Herman, A., and Haro, J. M. (2007). Mental disorders among adults with asthma: results from the World Mental Health Survey. General Hospital Psychiatry, 29(2):123-133.

Seaton, A., Godden, D., MacNee, W., and Donaldson, K. (1995). Particulate air pollution and acute health effects. The Lancet, 345(8943):176-178.

Seinfeld, J. H. and Pandis, S. N. (2016). Atmospheric Chemistry and Physics: From Air Pollution to Climate Change, 3rd Edition. John Wiley \& Sons, 3rd editio edition.

Sillman, S. (1999). The relation between ozone, $\mathrm{NO}(\mathrm{x})$ and hydrocarbons in urban and polluted rural environments. Atmospheric Environment, 33(12):1821-1845.

Sørensen, M., Daneshvar, B., Hansen, M., Dragsted, L. O., Hertel, O., Knudsen, L., and Loft, S. (2003). Personal PM2.5 exposure and markers of oxidative stress in blood. Environmental Health Perspectives, 111(2):161-166.

Stock, J. H. and Wright, J. H. (2000). GMM with weak identification. Econometrica, 68(5):1055-1096.

Suija, K., Timonen, M., Suviola, M., Jokelainen, J., Järvelin, M.-R., and Tammelin, T. (2013). The association between physical fitness and depressive symptoms among young adults: results of the Northern Finland 1966 birth cohort study. BMC Public Health, 13(1):535.

Sun, S., Stewart, J. D., Eliot, M. N., Yanosky, J. D., Liao, D., Tinker, L. F., Eaton, C. B., Whitsel, E. A., and Wellenius, G. A. (2019). Short-term exposure to air pollution and incidence of stroke in the Women's Health Initiative. Environment International, 132.

Wan, Z., Zhu, M., Chen, S., and Sperling, D. (2016). Pollution: Three steps to a green shipping industry. Nature, 530(7590):275-277.

Wang, M., Aaron, C. P., Madrigano, J., Hoffman, E. A., Angelini, E., Yang, J., Laine, A., Vetterli, T. M., Kinney, P. L., Sampson, P. D., Sheppard, L. E., Szpiro, A. A., Adar, S. D., 
Kirwa, K., Smith, B., Lederer, D. J., Diez-Roux, A. V., Vedal, S., Kaufman, J. D., and Barr, R. G. (2019). Association between long-term exposure to ambient air pollution and change in quantitatively assessed emphysema and lung function. JAMA, 322(6):546-556.

Wilkerson, J. T., Cullenward, D., Davidian, D., and Weyant, J. P. (2013). End use technology choice in the National Energy Modeling System (NEMS): An analysis of the residential and commercial building sectors. Energy Economics, 40:773-784.

Wooldridge, J. M. (2002). Econometric Analysis of Cross Section and Panel Data. MIT Press, Cambridge, MA.

Zhang, X., Zhang, X., and Chen, X. (2017). Happiness in the air: How does a dirty sky affect mental health and subjective well-being? Journal of Environmental Economics and Management, 85:81-94. 


\section{Tables and Figures}

Table 1: Effect of vessels in ports on air pollutant concentrations in the United States, instrumental variable estimation

\begin{tabular}{lcccc}
\hline \hline & \multicolumn{3}{c}{ Dependent variable: log of pollution concentration } \\
\cline { 2 - 5 } & $\mathrm{CO}$ & $\mathrm{NO}_{2}$ & $\mathrm{PM}_{2.5}$ & $\mathrm{SO}_{2}$ \\
& $(1)$ & $(2)$ & $(3)$ & $(4)$ \\
\hline Panel A: Vessel tonnage & & & & \\
Log of Vessel Tonnage & $0.37^{* * *}$ & $0.25^{* *}$ & $0.43^{* *}$ & $0.43^{* *}$ \\
& $(0.13)$ & $(0.12)$ & $(0.17)$ & $(0.19)$ \\
\cline { 2 - 5 } Adjusted R & 0.50 & 0.72 & 0.27 & 0.47 \\
Observations & 502,631 & 587,833 & 423,200 & 431,574 \\
\hline Panel B: Number of vessels & & & & $0.042^{* *}$ \\
Number of Vessels & $0.030^{* *}$ & $0.023^{* *}$ & $0.043^{* *}$ & $(0.021)$ \\
\cline { 2 - 5 } & $(0.012)$ & $(0.012)$ & $(0.019)$ & 0.48 \\
Adjusted $R^{2}$ & 0.54 & 0.74 & 0.37 & 431,574 \\
Observations & 502,631 & 587,833 & 423,200 & \\
\hline \hline
\end{tabular}

Notes: Panel A presents the instrumental variable estimation of the effect of log vessel tonnage on air pollutant concentrations within a 25-mile radius of ports in the United States. Panel B presents the same instrumental variable estimation using the number of vessels in ports as the variable of interest. Each entry presents an individual regression on a local air pollutant. The endogenous variables, vessel tonnage and the number of vessels, are instrumented by an indicator of seven-day lagged cyclones at least 500-mile distant from ports. All regressions include weather controls, such as the quadratics of maximum, minimum, and dew point temperature, precipitation, wind speed, and relative wind direction between a monitor-port pair. All regressions also include county-by-year, month, day-of-week, holiday, and monitor-port fixed effects. An observation is a monitor-port-day. Standard errors are clustered by monitor-port pair and day. Significance levels are indicated by *** $1 \%$, ** $5 \%$, and * $10 \%$. 
Table 2: Effect of air pollution on hospitalizaton rates in California port areas, instrumental variable estimation

\begin{tabular}{|c|c|c|c|c|c|c|}
\hline & \multicolumn{6}{|c|}{ Dependent variable: hospital visits/million residents } \\
\hline & \multicolumn{3}{|c|}{ Respiratory } & \multirow{2}{*}{$\begin{array}{c}\text { Heart } \\
\text { All } \\
\text { Heart } \\
(4)\end{array}$} & \multicolumn{2}{|c|}{ Psychiatric } \\
\hline & $\begin{array}{c}\text { Asthma } \\
\text { (1) }\end{array}$ & $\begin{array}{c}\text { Upper } \\
\text { Respiratory } \\
(2)\end{array}$ & $\begin{array}{c}\text { All } \\
\text { Respiratory } \\
\text { (3) }\end{array}$ & & $\begin{array}{c}\text { Anxiety } \\
\text { (5) }\end{array}$ & $\begin{array}{c}\text { All } \\
\text { Psychiatric } \\
(6)\end{array}$ \\
\hline \multicolumn{7}{|c|}{ Panel A: Overall population } \\
\hline $\mathrm{CO}(\mathrm{ppb})$ & $\begin{array}{l}0.01^{* * *} \\
(0.002)\end{array}$ & $\begin{array}{l}0.01^{* * *} \\
(0.003)\end{array}$ & $\begin{array}{l}0.05^{* * *} \\
(0.01)\end{array}$ & $\begin{array}{l}0.01^{* * *} \\
(0.003)\end{array}$ & $\begin{array}{l}0.003^{* * *} \\
(0.001)\end{array}$ & $\begin{array}{l}0.01^{* * *} \\
(0.003)\end{array}$ \\
\hline $\mathrm{NO}_{2}(\mathrm{ppb})$ & $\begin{array}{l}0.28^{* * *} \\
(0.05)\end{array}$ & $\begin{array}{l}0.34^{* * *} \\
(0.07)\end{array}$ & $\begin{array}{l}1.04^{* * *} \\
(0.19)\end{array}$ & $\begin{array}{l}0.37^{* * *} \\
(0.07)\end{array}$ & $\begin{array}{l}0.09^{* * *} \\
(0.03)\end{array}$ & $\begin{array}{l}0.23^{* * *} \\
(0.07)\end{array}$ \\
\hline $\mathrm{PM}_{2.5}\left(\mu \mathrm{g} / \mathrm{m}^{3}\right)$ & $\begin{array}{l}0.35^{* * *} \\
(0.06)\end{array}$ & $\begin{array}{l}0.42^{* * *} \\
(0.10)\end{array}$ & $\begin{array}{l}1.28^{* * *} \\
(0.26)\end{array}$ & $\begin{array}{l}0.43^{* * *} \\
(0.09)\end{array}$ & $\begin{array}{l}0.10^{* *} \\
(0.04)\end{array}$ & $\begin{array}{l}0.26^{* * * *} \\
(0.09)\end{array}$ \\
\hline $\mathrm{SO}_{2}(\mathrm{ppb})$ & $\begin{array}{l}7.36^{* * *} \\
(1.36)\end{array}$ & $\begin{array}{l}9.25^{* * *} \\
(2.11)\end{array}$ & $\begin{array}{c}27.47^{* * * *} \\
(5.57)\end{array}$ & $\begin{array}{l}9.99^{* * *} \\
(1.98)\end{array}$ & $\begin{array}{l}2.68^{* * *} \\
(0.85)\end{array}$ & $\begin{array}{l}6.95^{* * *} \\
(2.04)\end{array}$ \\
\hline \multicolumn{7}{|l|}{ Panel B: Black } \\
\hline $\mathrm{CO}(\mathrm{ppb})$ & $\begin{array}{l}0.04^{* * *} \\
(0.01)\end{array}$ & $\begin{array}{l}0.03^{* * *} \\
(0.01)\end{array}$ & $\begin{array}{l}0.09^{* * *} \\
(0.02)\end{array}$ & $\begin{array}{l}0.03^{* * *} \\
(0.01)\end{array}$ & $\begin{array}{c}0.004 \\
(0.004)\end{array}$ & $\begin{array}{c}-0.0001 \\
(0.01)\end{array}$ \\
\hline $\mathrm{NO}_{2}(\mathrm{ppb})$ & $\begin{array}{l}0.83^{* * *} \\
(0.20)\end{array}$ & $\begin{array}{l}1.03^{* * *} \\
(0.17)\end{array}$ & $\begin{array}{l}2.73^{* * *} \\
(0.50)\end{array}$ & $\begin{array}{l}0.71^{* * *} \\
(0.22)\end{array}$ & $\begin{array}{c}0.14 \\
(0.10)\end{array}$ & $\begin{array}{c}0.08 \\
(0.23)\end{array}$ \\
\hline $\mathrm{PM}_{2.5}\left(\mu \mathrm{g} / \mathrm{m}^{3}\right)$ & $\begin{array}{l}1.07^{* * *} \\
(0.24)\end{array}$ & $\begin{array}{l}1.22^{* * *} \\
(0.22)\end{array}$ & $\begin{array}{l}3.45^{* * *} \\
(0.62)\end{array}$ & $\begin{array}{l}0.73^{* * *} \\
(0.27)\end{array}$ & $\begin{array}{c}0.07 \\
(0.12)\end{array}$ & $\begin{array}{l}-0.09 \\
(0.28)\end{array}$ \\
\hline $\mathrm{SO}_{2}(\mathrm{ppb})$ & $\begin{array}{c}23.44^{* * *} \\
(5.28)\end{array}$ & $\begin{array}{c}35.53^{* * * *} \\
(5.13)\end{array}$ & $\begin{array}{l}85.74^{* * *} \\
(14.16)\end{array}$ & $\begin{array}{c}17.99^{* * *} \\
(6.11)\end{array}$ & $\begin{array}{l}4.50 \\
(2.80)\end{array}$ & $\begin{array}{l}4.55 \\
(6.34)\end{array}$ \\
\hline \multicolumn{7}{|l|}{ Panel C: White } \\
\hline $\mathrm{CO}(\mathrm{ppb})$ & $\begin{array}{l}0.01^{* * *} \\
(0.002)\end{array}$ & $\begin{array}{l}0.01^{* * *} \\
(0.002)\end{array}$ & $\begin{array}{l}0.04^{* * *} \\
(0.01)\end{array}$ & $\begin{array}{l}0.02^{* * *} \\
(0.01)\end{array}$ & $\begin{array}{c}0.001 \\
(0.002)\end{array}$ & $\begin{array}{l}0.01^{* *} \\
(0.01)\end{array}$ \\
\hline $\mathrm{NO}_{2}(\mathrm{ppb})$ & $\begin{array}{l}0.21^{* * *} \\
(0.05)\end{array}$ & $\begin{array}{l}0.21^{* * *} \\
(0.05)\end{array}$ & $\begin{array}{l}0.80^{* * *} \\
(0.17)\end{array}$ & $\begin{array}{l}0.42^{* * *} \\
(0.12)\end{array}$ & $\begin{array}{c}0.03 \\
(0.06)\end{array}$ & $\begin{array}{l}0.29^{* *} \\
(0.13)\end{array}$ \\
\hline $\mathrm{PM}_{2.5}\left(\mu \mathrm{g} / \mathrm{m}^{3}\right)$ & $\begin{array}{l}0.29^{* * *} \\
(0.08)\end{array}$ & $\begin{array}{l}0.28^{* * *} \\
(0.07)\end{array}$ & $\begin{array}{l}1.04^{* * * *} \\
(0.24)\end{array}$ & $\begin{array}{l}0.55^{* * *} \\
(0.17)\end{array}$ & $\begin{array}{c}0.05 \\
(0.08)\end{array}$ & $\begin{array}{l}0.37^{* *} \\
(0.19)\end{array}$ \\
\hline $\mathrm{SO}_{2}(\mathrm{ppb})$ & $\begin{array}{l}4.68^{* * *} \\
(1.47)\end{array}$ & $\begin{array}{l}5.23^{* * *} \\
(1.24)\end{array}$ & $\begin{array}{c}18.26^{* * *} \\
(4.48)\end{array}$ & $\begin{array}{c}10.01^{* * *} \\
(3.17)\end{array}$ & $\begin{array}{c}1.22 \\
(1.46)\end{array}$ & $\begin{array}{l}8.12^{* *} \\
(3.43)\end{array}$ \\
\hline
\end{tabular}

Notes: This table presents the instrumental variable estimation of the effect of air pollution on contemporaneous hospitalization rate for the overall population, Blacks, and whites. Each entry presents an individual regression of an air pollutant on an illness category. Pollution concentrations are instrumented by fitted vessel tonnage in ports, wind direction, wind speed, and their interactions. All regressions include weather controls, such as the quadratics of maximum, minimum, and dew point temperature, and precipitation. All regressions also include county-by-year, month, day-of-week, holiday, and zip code-port pair fixed effects. An observation is a zip code-port-day. Standard errors are clustered by zip code-port pair and day. Estimates are weighted by the zip code-specific population. Significance levels are indicated by ** $1 \%, * * 5 \%$, and $* 10 \%$. 
Table 3: Effect of one additional vessel in a port over an entire year on hospitalizations and medical costs in California

\begin{tabular}{lccc}
\hline \hline & $\begin{array}{c}\text { All } \\
\text { Respiratory } \\
(1)\end{array}$ & $\begin{array}{c}\text { All } \\
\text { Heart } \\
(2)\end{array}$ & $\begin{array}{c}\text { All } \\
\text { Psychiatric } \\
(3)\end{array}$ \\
\hline Panel A: Hospital visits per million residents & & \\
Black & 2,400 & 510 & 130 \\
White & 520 & 280 & 230 \\
Overall Population & 780 & 280 & 200 \\
\hline Panel B: Medical costs per capita (2017 USD) & & 1 \\
Black & 21 & 5 & 2 \\
White & 5 & 3 & 2 \\
Overall Population & 7 & 3 & 1 \\
\hline \hline
\end{tabular}

Notes: Panel A presents the back-of-the-envelope calculations of the effect of one additional vessel in port on annual hospitalizations, based on the instrumental variable estimates in Tables 1 and 2. Panel B presents the medical costs associated with the hospitalizations in Panel A based on the payment data from the Centers for Medicare and Medicaid Services. The average medical costs are $\$ 8,917$ for psychiatric illnesses, $\$ 8,715$ for respiratory illnesses, and $\$ 9,679$ for heart-related illnesses. Based on the U.S. 2010 Decennial Census, the total population residing in the zip codes within 25 miles of California's major ports is 15.08 million, where 1.12 million are Black, and 5.07 million are white. All numbers are rounded to two significant figures.

Table 4: Placebo test on the effect of the cyclone instrument on air pollutant concentrations in distant areas

\begin{tabular}{lcccc}
\hline \hline & \multicolumn{4}{c}{ Dependent variable: log of pollution concentration } \\
\cline { 2 - 5 } & $\mathrm{CO}$ & $\mathrm{NO}_{2}$ & $\mathrm{PM}_{2.5}$ & $\mathrm{SO}_{2}$ \\
& $(1)$ & $(2)$ & $(3)$ & $(4)$ \\
\hline Tropical Cyclone & 0.01 & -0.01 & -0.01 & -0.03 \\
& $(0.01)$ & $(0.01)$ & $(0.01)$ & $(0.02)$ \\
\hline Adjusted R & 0.47 & 0.77 & 0.40 & 0.54 \\
Observations & 85,970 & 141,201 & 101,324 & 61,458 \\
\hline \hline
\end{tabular}

Notes: This table presents the placebo test on regressing the instrumental variable of seven-day lagged cyclones that are at least 500-mile distant from ports on air pollutant concentrations in certain areas that are far from ports (i.e., 75-100 miles from major U.S. ports). Each column presents an individual regression on a local air pollutant. All regressions include weather controls, such as quadratics of maximum, minimum, and dew point temperatures, precipitation, wind speed, and wind direction. All regressions also include county-by-year, month, day-of-week, holiday, and pollution monitor fixed effects. An observation is a monitor-day. Standard errors are clustered by pollution monitor and day. Significance levels are indicated by ${ }^{* * *} 1 \%$, ** $5 \%$, and * $10 \%$. 
Table 5: Effect of California Ocean-Going Vessel At-Berth Regulation on air pollution, RDD estimation

\begin{tabular}{lcccc}
\hline \hline & \multicolumn{4}{c}{ Dependent variable: residual of log pollution concentration } \\
\cline { 2 - 5 } & $\mathrm{CO}$ & $\mathrm{NO}_{2}$ & $\mathrm{PM}_{2.5}$ & $\mathrm{SO}_{2}$ \\
& $(1)$ & $(2)$ & $(3)$ & $(4)$ \\
\hline CA Regulation & $-0.12^{*}$ & $-0.20^{* *}$ & 0.17 & -0.17 \\
& $(0.07)$ & $(0.09)$ & $(0.10)$ & $(0.21)$ \\
Date & $0.005^{* * *}$ & $0.004^{* *}$ & 0.002 & $0.01^{* *}$ \\
& $(0.002)$ & $(0.002)$ & $(0.002)$ & $(0.004)$ \\
CA Regulation $\times$ Date & $-0.01^{* * *}$ & $-0.004^{*}$ & $-0.01^{* * *}$ & -0.01 \\
& $(0.003)$ & $(0.002)$ & $(0.003)$ & $(0.01)$ \\
\hline Pre-policy Mean & 608.01 & 18.36 & 14.54 & 1.83 \\
Observations & 4,710 & 5,288 & 2,928 & 3,171 \\
\hline \hline
\end{tabular}

Notes: This table presents the second-stage augmented local linear RDD estimation of the effect of the California at-berth regulation on air pollutant concentrations. The second-stage RDD dependent variable is taken from the residuals by regressing log pollution concentrations on weather controls (i.e., the quadratics of maximum, minimum, and dew point temperature, precipitation, wind speed, and relative wind direction between a monitor-port pair), fixed effects (i.e., county-by-year, month, day-of-week, holiday, and port-monitor pair), and log vessel tonnage (instrumented by seven-day lagged and 500-mile distant cyclones from ports). The local linear bandwidth is specified as 65 days on both sides of the policy threshold. An observation is a monitor-port-day. Standard errors are clustered by monitor-port pair and normalized day. Significance levels are indicated by ${ }^{* * *} 1 \%, * * 5 \%$, and ${ }^{*} 10 \%$.

Table 6: Effect of California Ocean-Going Vessel At-Berth Regulation on annual hospitalizations and medical costs

\begin{tabular}{lccc}
\hline \hline & $\begin{array}{c}\text { All } \\
\text { Respiratory } \\
(1)\end{array}$ & $\begin{array}{c}\text { All } \\
\text { Heart } \\
(2)\end{array}$ & $\begin{array}{c}\text { All } \\
\text { Psychiatric } \\
(3)\end{array}$ \\
\hline Panel A: Hospital visits per million residents & & \\
Black & $-7,900$ & $-1,600$ & -420 \\
White & $-1,700$ & -920 & -740 \\
Overall Population & $-2,500$ & -920 & -640 \\
\hline Panel B: Medical costs per capita (2017 USD) & & \\
Black & -69 & -15 & -4 \\
White & -15 & -9 & -7 \\
Overall Population & -22 & -9 & -6 \\
\hline \hline
\end{tabular}

Notes: Panel A presents the back-of-the-envelope calculations of the effect of the California at-berth regulation on annual hospitalizations based on the estimates in Tables 2 and 5. Panel B presents the medical costs associated with the hospital visits in Panel A based on the payment data from Centers for Medicare and Medicaid Services. The average medical costs are $\$ 8,917$ for psychiatric illnesses, $\$ 8,715$ for respiratory illnesses, and $\$ 9,679$ for heart-related illnesses. Based on the US 2010 Decennial Census, total population residing in the zip codes within 25 miles of the major ports in California is 15.08 million, in which 1.12 million are Black and 5.07 million are white. All numbers are rounded to two significant figures. 

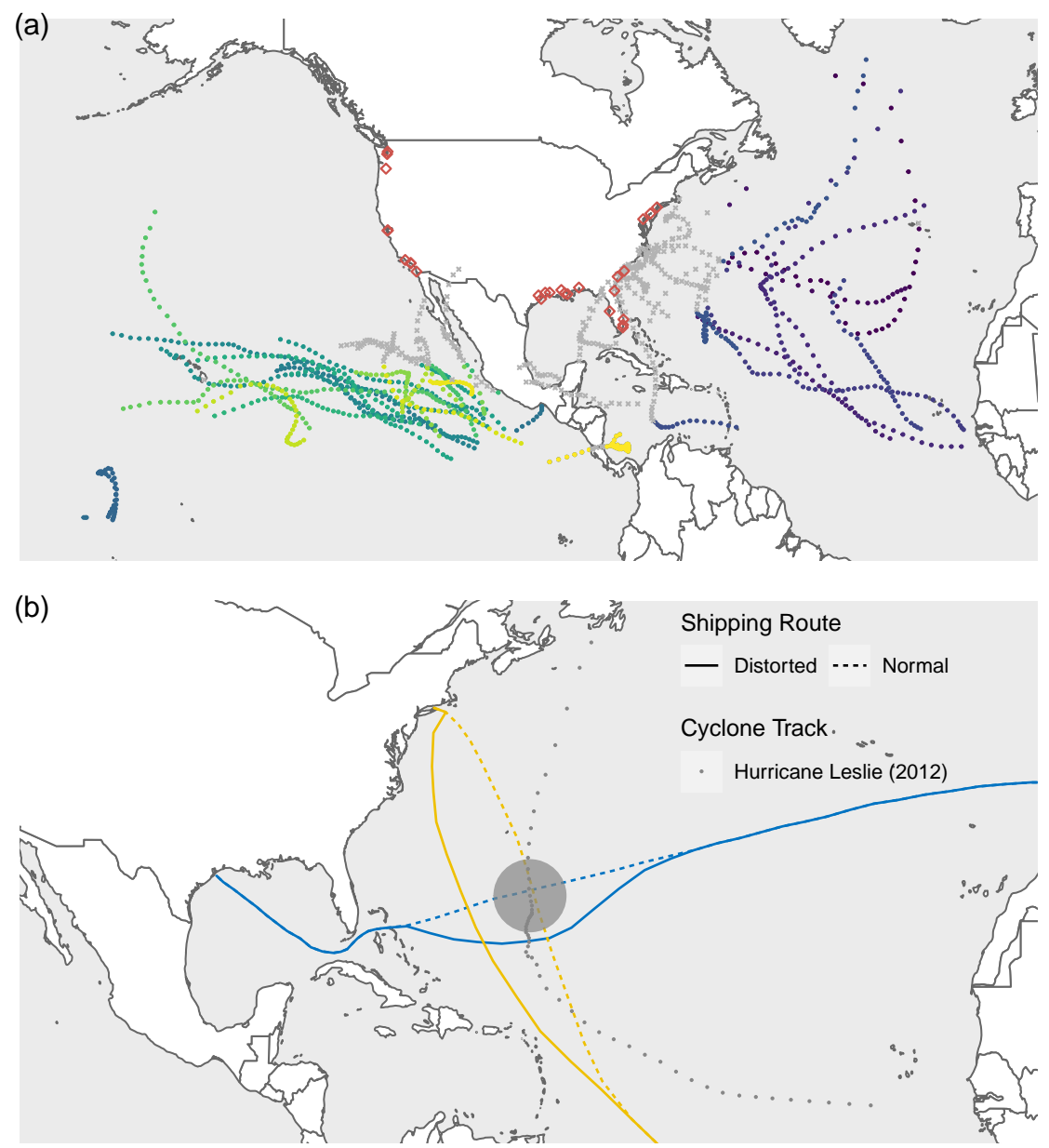

Figure 1: (a) Locations of major ports and tracks of tropical cyclones. (b) Illustrative shipping routes and a tropical cyclone track.

Notes: Panel (a) plots the locations of major ports (red diamonds) in the United States and the tracks of tropical cyclones (colored dots) in the Northeast and North Central Pacific Ocean and the Atlantic Ocean in 2016. The gray $\times$ dots indicate the cyclone observations within 500 miles of ports or on land. Panel (b) plots two shipping routes to U.S. ports and the track of Hurricane Leslie in 2012. The solid lines indicate the distorted routes in response to the cyclone, while the dashed lines represent the normal routes. The grey dots and round represent Hurricane Leslie. The hurricane data are obtained from the NOAA National Hurricane Center, and the shipping routes are approximated based on data from the online tool: https://www.shipmap.org. 

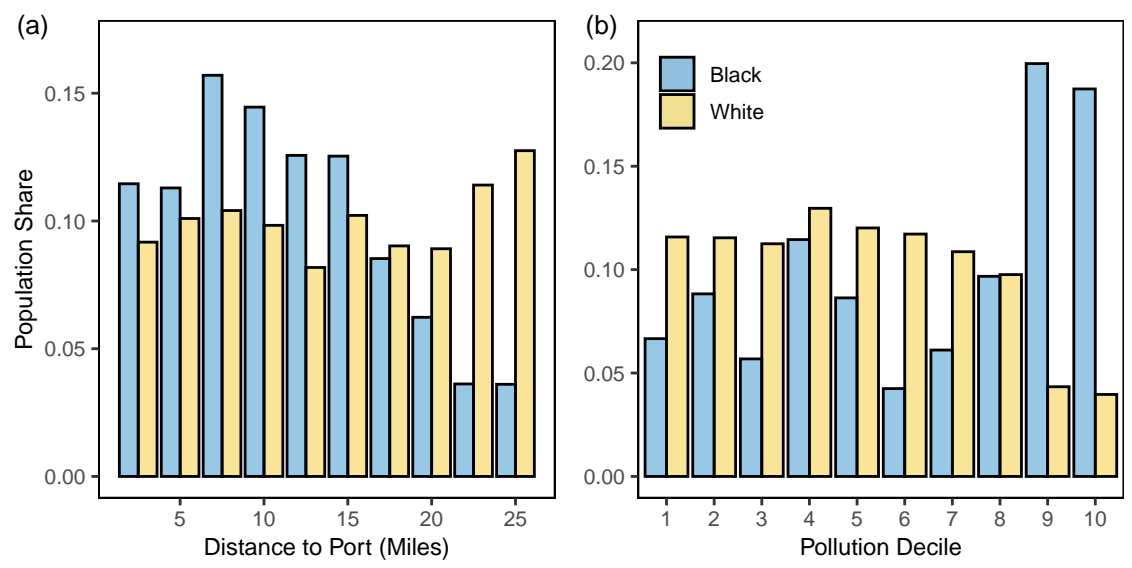

Figure 2: (a) Distribution of population by distance to major California ports. (b) Distribution of the population in California port areas by decile of $\mathrm{PM}_{2.5}$ concentration.

Notes: Panel (a) plots population distribution in the California port areas by the distance between census tract and port, separately for non-Hispanic Black and white populations. We obtain population data at the census tract level and assign a distance between a census tract to its nearest mapped port to all race-specific populations within the census tract. Panel (b) plots population distribution in the California port areas by decile of $\mathrm{PM}_{2.5}$ concentration, separately for non-Hispanic Black and white population. Larger pollution deciles represent higher pollution exposures. The data are acquired from the U.S. 2010 Decennial Census and U.S. EPA Air Quality System.

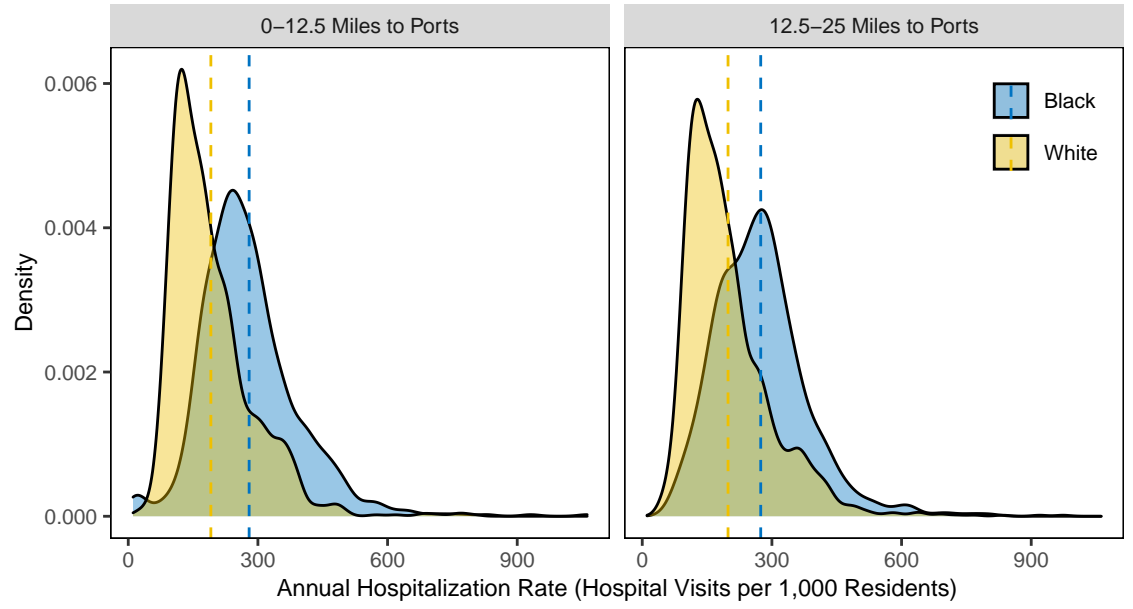

Figure 3: Distribution of annual hospitalizations rates in California port areas.

Notes: This figure plots the distribution density of annual hospitalization rates separately for non-Hispanic Black and white population in the areas within 0-12.5 miles from ports and 12.5-25 miles from ports in California. The hospitalization rate is calculated as the annual total hospital visits related to psychiatric, respiratory, and heart-related illnesses in each zip code for 2010-2016. The dashed lines represent sample means. The gap between the dashed lines in the left panel is 87 , while the gap in the right panel is 81 . We exclude the zip codes having less than 1,000 race-specific populations in our analysis. The data are obtained from the Office of Statewide Health Planning and Development of California. 


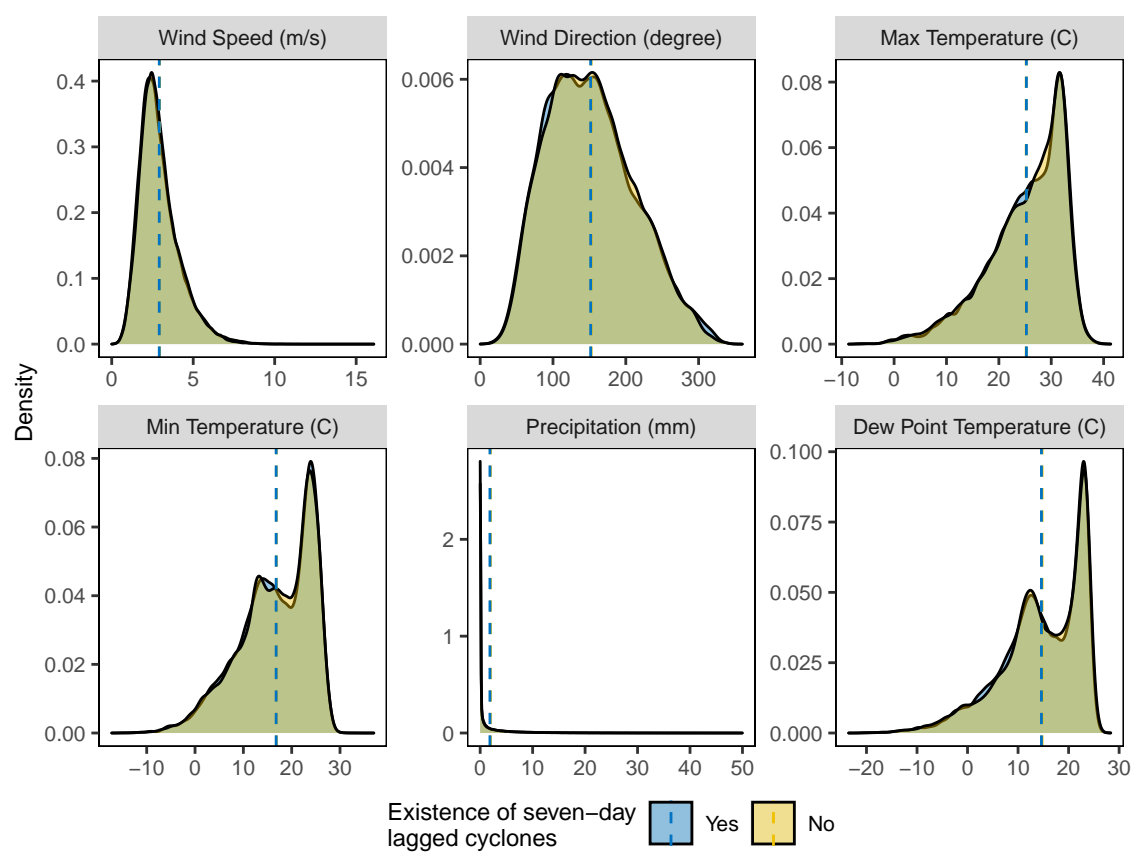

Figure 4: Distribution of local weather in port areas.

Notes: This figure presents the density of weather measures in the U.S. port areas, separately for the month-days when there exist seven-day lagged and 500-mile distant tropical cyclones in the ocean and the same month-days when there are no such cyclones. The dashed lines represent the means of the distributions. We do not plot the observations with precipitation greater than 50 . The data are obtained from the NOAA Integrated Surface Database. 

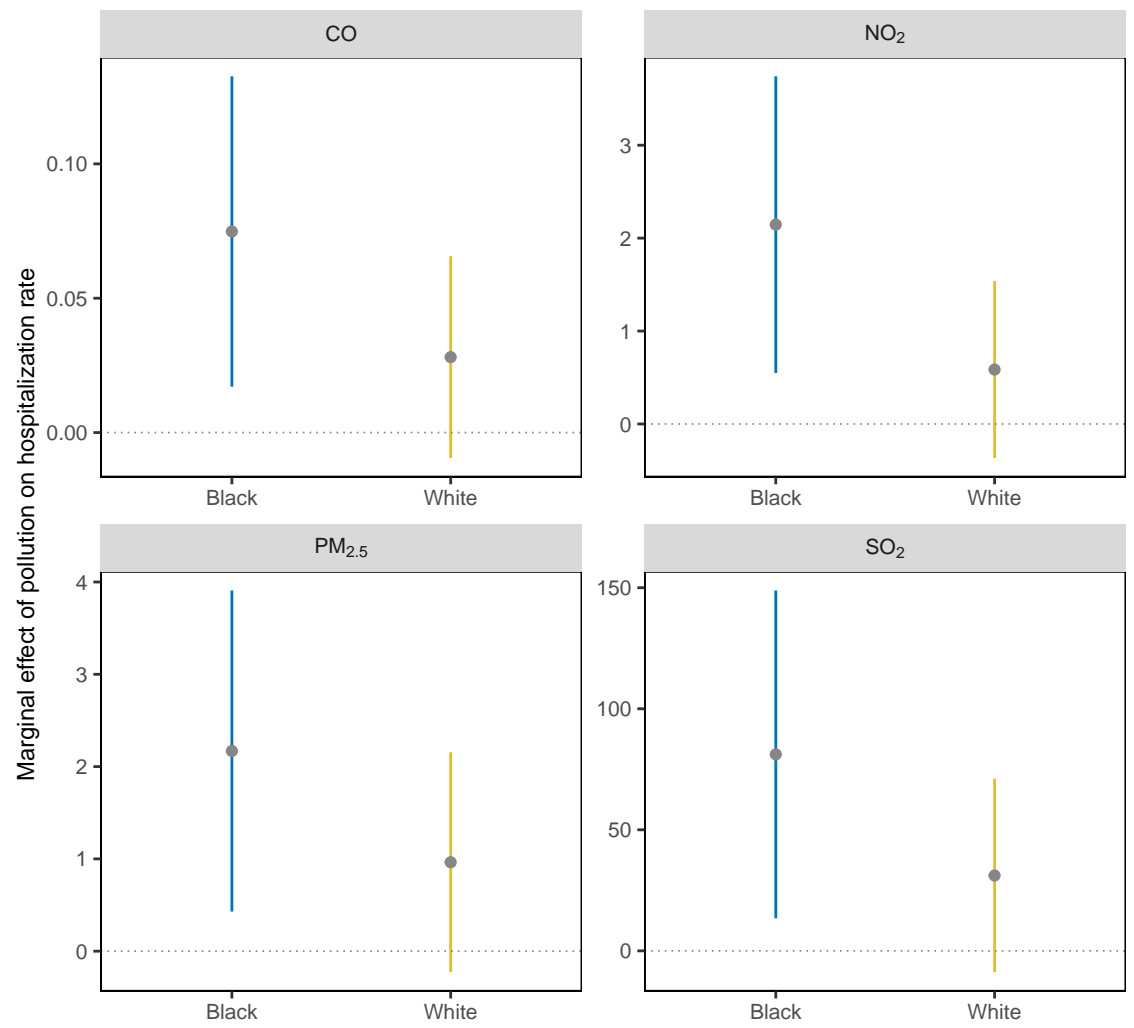

Figure 5: Marginal effects of pollution on hospitalization rates by race in zip codes with a similar distance to ports and pollution exposures.

Notes: This figure plots marginal effects of pollution on total hospitalization rates related to respiratory, heart, and psychiatric illnesses by race in zip codes with a similar distance to ports (within 11-20 miles to ports) and pollution exposures (with 11-12 $\mu \mathrm{g} / \mathrm{m}^{3}$ annual $\mathrm{PM}_{2.5}$ concentrations). Error bars correspond to $95 \%$ confidence intervals, where standard errors from regressions are clustered by port-zip code and day. An observation is a zip code-port-day. 


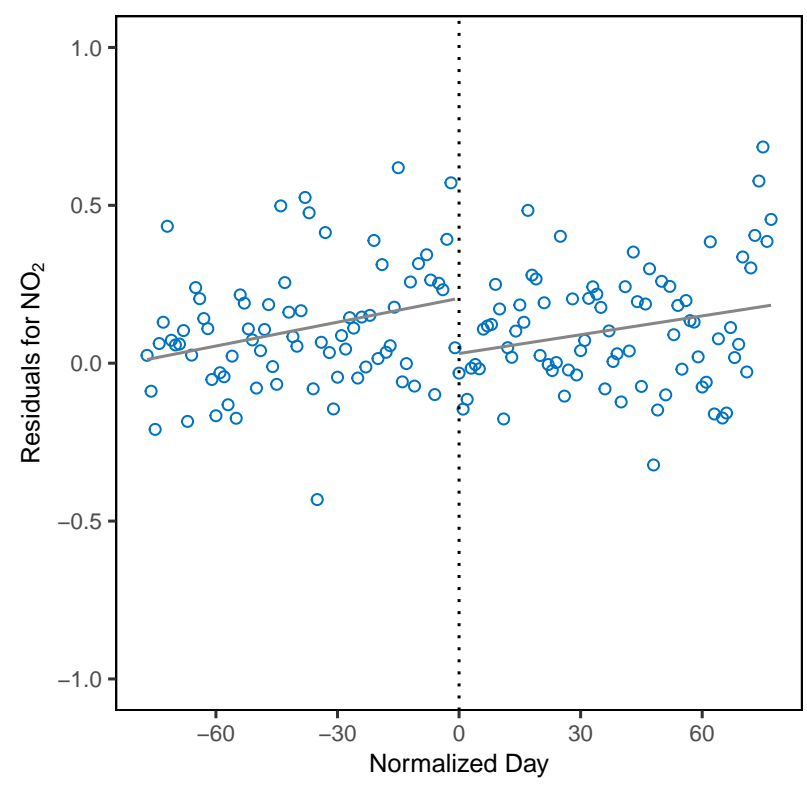

Figure 6: Residuals of $\mathrm{NO}_{2}$ concentrations for the RDD analysis.

Notes: This figure plots daily average residuals across all monitor-port pairs for $\mathrm{NO}_{2}$. The grey solid lines are linear fitted lines of the residuals. The policy date is normalized to be zero, indicated by the vertical dotted lines. A few extreme values are not shown in the figure. 


\section{A Supplementary Tables (For Online Publication)}

Table A.1: Summary statistics of the major ports in United States

\begin{tabular}{|c|c|c|c|c|c|c|c|c|}
\hline & \multicolumn{4}{|c|}{ Vessel Tonnage (100,000 Mt) } & \multicolumn{4}{|c|}{ Vessel Counts } \\
\hline & Mean & $\begin{array}{l}\text { Standard } \\
\text { Deviation }\end{array}$ & Min & Max & Mean & $\begin{array}{l}\text { Standard } \\
\text { Deviation }\end{array}$ & Min & Max \\
\hline Houston, TX & 12.38 & 3.39 & 1.34 & 36 & 53.93 & 12.24 & 8.00 & 157 \\
\hline Long Beach, CA & 9.77 & 3.44 & 0.00 & 25 & 18.75 & 5.78 & 0.00 & 55 \\
\hline New York, NY and NJ & 8.23 & 2.81 & 0.41 & 49 & 21.02 & 7.21 & 1.00 & 142 \\
\hline Los Angeles, CA & 7.41 & 2.99 & 0.00 & 26 & 15.25 & 5.64 & 0.00 & 49 \\
\hline South Louisiana, LA, Port of & 7.18 & 2.75 & 0.98 & 18 & 22.77 & 7.25 & 4.00 & 51 \\
\hline New Orleans, LA & 4.89 & 1.55 & 0.29 & 12 & 19.39 & 5.69 & 2.00 & 46 \\
\hline Baltimore, MD & 4.87 & 2.10 & 0.09 & 16 & 12.91 & 4.24 & 1.00 & 50 \\
\hline Savannah, GA & 3.94 & 1.74 & 0.00 & 12 & 10.51 & 3.49 & 0.00 & 29 \\
\hline Oakland, CA & 3.71 & 1.94 & 0.00 & 24 & 6.92 & 3.50 & 0.00 & 53 \\
\hline Seattle, WA & 3.53 & 1.48 & 0.24 & 11 & 24.43 & 5.05 & 1.00 & 46 \\
\hline Miami, FL & 3.51 & 1.88 & 0.11 & 11 & 24.39 & 7.17 & 5.00 & 57 \\
\hline Port Everglades, FL & 3.33 & 2.24 & 0.04 & 14 & 17.75 & 4.40 & 4.00 & 40 \\
\hline Charleston, SC & 3.23 & 1.19 & 0.00 & 9 & 8.40 & 2.90 & 0.00 & 26 \\
\hline Tacoma, WA & 2.85 & 1.49 & 0.04 & 14 & 14.43 & 4.46 & 1.00 & 34 \\
\hline Beaumont, TX & 2.70 & 1.20 & 0.00 & 8 & 7.27 & 2.93 & 0.00 & 20 \\
\hline Mobile, AL & 2.68 & 1.03 & 0.06 & 7 & 12.17 & 3.95 & 1.00 & 31 \\
\hline Jacksonville, FL & 2.20 & 1.00 & 0.00 & 8 & 8.07 & 3.03 & 0.00 & 23 \\
\hline Portland, OR & 1.80 & 1.00 & 0.00 & 7 & 7.66 & 3.92 & 0.00 & 29 \\
\hline Philadelphia, PA & 1.61 & 1.02 & 0.00 & 6 & 3.76 & 2.07 & 0.00 & 21 \\
\hline Tampa, FL & 1.61 & 0.82 & 0.00 & 6 & 7.56 & 3.30 & 0.00 & 25 \\
\hline Baton Rouge, LA & 1.47 & 0.79 & 0.00 & 6 & 5.27 & 2.48 & 0.00 & 17 \\
\hline Galveston, TX & 1.46 & 1.05 & 0.00 & 7 & 10.92 & 4.69 & 0.00 & 31 \\
\hline Lake Charles, LA & 1.43 & 0.72 & 0.00 & 4 & 7.70 & 3.35 & 0.00 & 23 \\
\hline San Diego, CA & 0.83 & 0.67 & 0.00 & 6 & 4.34 & 2.37 & 0.00 & 15 \\
\hline Port Hueneme, CA & 0.46 & 0.40 & 0.00 & 2 & 1.67 & 1.28 & 0.00 & 6 \\
\hline Palm Beach, FL & 0.33 & 0.22 & 0.00 & 3 & 6.16 & 3.25 & 0.00 & 19 \\
\hline San Francisco, CA & 0.30 & 0.48 & 0.00 & 4 & 0.71 & 1.07 & 0.00 & 11 \\
\hline
\end{tabular}

Notes: This table presents the summary statistics of daily vessel tonnage and daily mean vessel counts for the 27 major ports in the United States. The data are obtained from the U.S. Army Corps of Engineers. 
Table A.2: ICD-9-CM, ICD-10-CM, and MS-DRG codes

\begin{tabular}{|c|c|c|c|}
\hline & ICD-9 Code & ICD-10 Code & MS-DRG Code \\
\hline \multicolumn{4}{|l|}{ Panel A: Respiratory } \\
\hline Asthma & 493 & $\mathrm{~J} 45$ & 202,203 \\
\hline Upper Respiratory & $460-465$ & J00-J06 & $011-013,152,153$ \\
\hline All Respiratory & $460-519$ & J00-J99 & $\begin{array}{l}011-013,152-156,177-182, \\
186-206,793,865,866, \\
919-921,928,929,951\end{array}$ \\
\hline \multicolumn{4}{|l|}{ Panel B: Heart } \\
\hline All Heart & $410-429$ & I20-I52 & $\begin{array}{l}175,176,222-227,280-285, \\
288-293,296-298,302,303, \\
306-311,314-316,793\end{array}$ \\
\hline \multicolumn{4}{|l|}{ Panel C: Psychiatric } \\
\hline Anxiety & $300.0,300.2$ & $\mathrm{~F} 40, \mathrm{~F} 41$ & 880,882 \\
\hline All Psychiatric & $\begin{array}{l}300.0,300.2,296.0, \\
296.4-296.9,309.0, \\
309.2-309.4,295,308.9, \\
309.8,314.0,314.2,314.9, \\
312.0-312.2,312.8,312.9, \\
313.8,299.0,299.8,312.3, \\
307.9,311,296.2,296.3, \\
296.8,296.9,298.0,300.4, \\
625.4,301.10,301.12, \\
301.13,301.0,301.3, \\
301.4,301.6-301.9,301.50, \\
301.59\end{array}$ & $\begin{array}{l}\text { F43.2, F43.8, F43.9, F20, } \\
\text { F22-F25, F28, F29, F43.0, } \\
\text { F43.1, F90, F91, F84.0, } \\
\text { F84.5, F84.8, F63, F32, } \\
\text { F33, F34.0, F34,1, F60 }\end{array}$ & $880-886$ \\
\hline \multicolumn{4}{|l|}{ Panel D: Placebo } \\
\hline Arterial Embolism & 444 & $\mathrm{I} 74$ & . \\
\hline Neck Wound & 874 & S11 & . \\
\hline Appendicitis & $540-543$ & K35-K38 & . \\
\hline
\end{tabular}

Notes: Table presents the ICD-9-CM, and ICD-10-CM codes for counting hospital visits for the illness groups examined in the paper and the corresponding MS-DRG code for calculating average medical costs for each illness group. The codes include the ranges of themselves and any subcategories. We do not calculate medical costs for the placebo diseases. 
Table A.3: Summary statistics of main variables

\begin{tabular}{|c|c|c|c|c|c|c|c|c|}
\hline & \multicolumn{4}{|c|}{ Within 25 Miles of US Ports } & \multicolumn{4}{|c|}{ Within 25 Miles of CA Ports } \\
\hline & Mean & $\begin{array}{l}\text { Standard } \\
\text { Deviation }\end{array}$ & Min & Max & Mean & $\begin{array}{l}\text { Standard } \\
\text { Deviation }\end{array}$ & Min & Max \\
\hline \multicolumn{9}{|l|}{ Panel A: Port } \\
\hline Tonnage $(100,000 \mathrm{Mt})$ & 3.63 & 3.47 & 0.00 & 49.30 & 3.75 & 4.21 & 0.00 & 26.07 \\
\hline Vessel Counts & 13.11 & 11.59 & 0.00 & 157.00 & 7.94 & 7.77 & 0.00 & 55.00 \\
\hline \multicolumn{9}{|l|}{ Panel B: Pollution } \\
\hline CO Max (ppb) & 808.17 & 661.10 & 0.00 & 12950.00 & 900.77 & 769.08 & 0.00 & 12950.00 \\
\hline CO Mean (ppb) & 485.97 & 360.64 & 0.00 & 4994.11 & 525.60 & 394.61 & 0.00 & 4994.11 \\
\hline $\mathrm{NO}_{2} \mathrm{Max}(\mathrm{ppb})$ & 25.17 & 15.48 & 0.00 & 268.00 & 28.11 & 16.63 & 0.00 & 163.00 \\
\hline $\mathrm{NO}_{2}$ Mean (ppb) & 13.27 & 9.97 & 0.00 & 83.43 & 15.66 & 10.91 & 0.00 & 83.43 \\
\hline $\mathrm{O}_{3} \mathrm{Max}(\mathrm{ppb})$ & 37.52 & 14.69 & 0.00 & 144.00 & 37.04 & 13.19 & 0.00 & 114.00 \\
\hline $\mathrm{O}_{3}$ Mean $(\mathrm{ppb})$ & 26.98 & 11.73 & 0.00 & 100.71 & 26.46 & 11.23 & 0.00 & 84.77 \\
\hline $\mathrm{PM}_{2.5} \operatorname{Max}\left(\mu \mathrm{g} / \mathrm{m}^{3}\right)$ & 11.58 & 7.17 & 0.00 & 265.90 & 13.25 & 7.93 & 0.00 & 112.40 \\
\hline $\mathrm{PM}_{2.5}$ Mean $\left(\mu \mathrm{g} / \mathrm{m}^{3}\right)$ & 10.67 & 6.66 & 0.00 & 90.30 & 11.56 & 7.47 & 0.00 & 90.30 \\
\hline $\mathrm{SO}_{2} \mathrm{Max}(\mathrm{ppb})$ & 6.01 & 9.72 & 0.00 & 346.65 & 3.03 & 3.26 & 0.00 & 96.50 \\
\hline $\mathrm{SO}_{2}$ Mean (ppb) & 2.32 & 3.29 & 0.00 & 78.61 & 1.44 & 1.48 & 0.00 & 20.90 \\
\hline \multicolumn{9}{|c|}{ Panel C: Health (hospital visits per million residents) } \\
\hline Asthma & . & . & . & . & 65.92 & 63.32 & 0.00 & 3572.04 \\
\hline Upper Respiratory & . & . & . & . & 41.46 & 49.29 & 0.00 & 3912.23 \\
\hline All Respiratory & . & . & . & . & 222.98 & 145.24 & 0.00 & 12791.29 \\
\hline All Heart & . & . & . & . & 140.10 & 92.56 & 0.00 & 1339.42 \\
\hline Anxiety & . & . & . & . & 46.08 & 47.71 & 0.00 & 743.83 \\
\hline All Psychiatric & . & . & . & . & 138.82 & 108.83 & 0.00 & 2231.48 \\
\hline Arterial Embolism & . & . & . & . & 0.66 & 5.14 & 0.00 & 297.53 \\
\hline Neck Wound & . & . & . & . & 0.23 & 3.10 & 0.00 & 392.62 \\
\hline Appendicitis & . & . & . & . & 4.03 & 12.72 & 0.00 & 431.78 \\
\hline
\end{tabular}

Notes: This table presents summary statistics of the main variables, including mean, standard deviation, minimum, and maximum. The variables are split into three panels, i.e., port, pollution, and health. The data are obtained from the U.S. Army Corps of Engineers, the U.S. EPA Air Quality System, and the Office of Statewide Health Planning and Development of California. 
Table A.4: Summary statistics of hospitalization rate by race group

\begin{tabular}{|c|c|c|c|c|c|c|}
\hline & \multicolumn{3}{|c|}{ Respiratory } & \multirow{2}{*}{$\begin{array}{c}\frac{\text { Heart }}{\text { All }} \\
\text { Heart }\end{array}$} & \multicolumn{2}{|c|}{ Psychiatric } \\
\hline & Asthma & $\begin{array}{c}\text { Upper } \\
\text { Respiratory }\end{array}$ & $\begin{array}{c}\text { All } \\
\text { Respiratory }\end{array}$ & & Anxiety & $\begin{array}{c}\text { All } \\
\text { Psychiatric }\end{array}$ \\
\hline \multicolumn{7}{|c|}{ Panel A: Black } \\
\hline Mean & 197.97 & 91.91 & 513.65 & 234.94 & 66.26 & 272.53 \\
\hline Std. Dev. & 291.81 & 201.14 & 548.76 & 318.45 & 169.37 & 404.21 \\
\hline Min & 0.00 & 0.00 & 0.00 & 0.00 & 0.00 & 0.00 \\
\hline Max & 5771.08 & 4488.62 & 16992.63 & 4664.18 & 2991.03 & 6511.63 \\
\hline \multicolumn{7}{|c|}{ Panel B: White } \\
\hline Mean & 78.47 & 33.89 & 286.53 & 227.15 & 74.07 & 243.01 \\
\hline Std. Dev. & 133.41 & 90.76 & 312.34 & 235.70 & 125.22 & 304.28 \\
\hline Min & 0.00 & 0.00 & 0.00 & 0.00 & 0.00 & 0.00 \\
\hline Max & 4248.09 & 3992.02 & 9398.50 & 4436.56 & 2851.71 & 8458.65 \\
\hline
\end{tabular}

Notes: This table presents summary statistics of hospitalization rates (i.e., hospital visits per million residents) by race group, including mean, standard deviation, minimum, and maximum. The data are obtained Office of Statewide Health Planning and Development of California.

Table A.5: Summary statistics of hospitalization rate by age group

\begin{tabular}{|c|c|c|c|c|c|c|}
\hline & \multicolumn{3}{|c|}{ Respiratory } & \multirow{2}{*}{$\begin{array}{c}\frac{\text { Heart }}{\text { All }} \\
\text { Heart }\end{array}$} & \multicolumn{2}{|c|}{ Psychiatric } \\
\hline & Asthma & $\begin{array}{c}\text { Upper } \\
\text { Respiratory }\end{array}$ & $\begin{array}{c}\text { All } \\
\text { Respiratory }\end{array}$ & & Anxiety & $\begin{array}{c}\text { All } \\
\text { Psychiatric }\end{array}$ \\
\hline \multicolumn{7}{|c|}{ Panel A: Ages 5 and under } \\
\hline Mean & 72.39 & 244.92 & 479.01 & 8.16 & 0.70 & 5.42 \\
\hline Std. Dev. & 185.40 & 360.17 & 589.39 & 61.62 & 17.46 & 50.16 \\
\hline Min & 0.00 & 0.00 & 0.00 & 0.00 & 0.00 & 0.00 \\
\hline Max & 4634.99 & 5867.56 & 11973.74 & 1988.07 & 983.28 & 2320.19 \\
\hline \multicolumn{7}{|c|}{ Panel B: Ages between 5 and 19} \\
\hline Mean & 56.02 & 49.55 & 146.44 & 4.68 & 13.32 & 54.33 \\
\hline Std. Dev. & 116.40 & 109.09 & 220.10 & 33.52 & 57.33 & 132.52 \\
\hline Min & 0.00 & 0.00 & 0.00 & 0.00 & 0.00 & 0.00 \\
\hline Max & 4779.84 & 4490.15 & 13035.92 & 1937.98 & 1937.98 & 3875.97 \\
\hline \multicolumn{7}{|c|}{ Panel C: Ages between 20 and 64} \\
\hline Mean & 58.16 & 23.87 & 155.89 & 69.97 & 50.86 & 148.31 \\
\hline Std. Dev. & 71.24 & 42.25 & 141.49 & 73.55 & 60.99 & 134.39 \\
\hline Min & 0.00 & 0.00 & 0.00 & 0.00 & 0.00 & 0.00 \\
\hline Max & 3310.12 & 4280.33 & 13640.00 & 1416.43 & 1045.21 & 2351.71 \\
\hline \multicolumn{7}{|c|}{ Panel D: Ages 65 and above } \\
\hline Mean & 120.55 & 18.44 & 573.24 & 780.55 & 96.32 & 285.57 \\
\hline Std. Dev. & 199.89 & 76.38 & 486.90 & 529.20 & 175.61 & 345.58 \\
\hline Min & 0.00 & 0.00 & 0.00 & 0.00 & 0.00 & 0.00 \\
\hline Max & 3791.47 & 2521.01 & 11764.71 & 7582.94 & 3731.34 & 6529.85 \\
\hline
\end{tabular}

Notes: This table presents summary statistics of hospitalization rates (i.e., hospital visits per million residents) by age group, including mean, standard deviation, minimum, and maximum. The data are obtained Office of Statewide Health Planning and Development of California. 
Table A.6: Summary statistics of hospitalization rate by sex group

\begin{tabular}{|c|c|c|c|c|c|c|}
\hline & \multicolumn{3}{|c|}{ Respiratory } & \multirow{2}{*}{$\begin{array}{c}\frac{\text { Heart }}{\text { All }} \\
\text { Heart }\end{array}$} & \multicolumn{2}{|c|}{ Psychiatric } \\
\hline & Asthma & $\begin{array}{c}\text { Upper } \\
\text { Respiratory }\end{array}$ & $\begin{array}{c}\text { All } \\
\text { Respiratory }\end{array}$ & & Anxiety & $\begin{array}{c}\text { All } \\
\text { Psychiatric }\end{array}$ \\
\hline \multicolumn{7}{|c|}{ Panel A: Male } \\
\hline Mean & 52.42 & 39.32 & 207.14 & 151.64 & 33.22 & 114.51 \\
\hline Std. Dev. & 70.79 & 59.99 & 166.07 & 128.72 & 54.41 & 126.34 \\
\hline Min & 0.00 & 0.00 & 0.00 & 0.00 & 0.00 & 0.00 \\
\hline Max & 3523.27 & 3252.25 & 11518.40 & 2088.62 & 1135.07 & 2683.96 \\
\hline \multicolumn{7}{|c|}{ Panel B: Female } \\
\hline Mean & 79.31 & 43.74 & 238.96 & 129.20 & 58.69 & 162.38 \\
\hline Std. Dev. & 90.99 & 64.77 & 187.83 & 111.88 & 72.75 & 149.32 \\
\hline Min & 0.00 & 0.00 & 0.00 & 0.00 & 0.00 & 0.00 \\
\hline Max & 3621.21 & 4782.73 & 14006.56 & 1642.58 & 1314.06 & 2956.64 \\
\hline
\end{tabular}

Notes: This table presents summary statistics of hospitalization rates (i.e., hospital visits per million residents) by sex group, including mean, standard deviation, minimum, and maximum. The data are obtained Office of Statewide Health Planning and Development of California. 
Table A.7: Summary statistics of hospitalization rate by time window following pollution exposure

\begin{tabular}{|c|c|c|c|}
\hline & $\begin{array}{c}\text { All } \\
\text { Respiratory }\end{array}$ & $\begin{array}{c}\text { All } \\
\text { Heart }\end{array}$ & $\begin{array}{c}\text { All } \\
\text { Psychiatric } \\
\end{array}$ \\
\hline \multicolumn{4}{|c|}{ Panel A: 3-day Time Window } \\
\hline Mean & 668.91 & 420.41 & 416.56 \\
\hline Std. Dev. & 354.38 & 199.19 & 250.32 \\
\hline Min & 0.00 & 0.00 & 0.00 \\
\hline Max & 34903.90 & 3044.14 & 4077.47 \\
\hline \multicolumn{4}{|c|}{ Panel B: 5-day Time Window } \\
\hline Mean & 1114.78 & 700.86 & 694.46 \\
\hline Std. Dev. & 555.92 & 294.57 & 383.89 \\
\hline Min & 0.00 & 0.00 & 0.00 \\
\hline Max & 49124.00 & 4566.21 & 5861.37 \\
\hline \multicolumn{4}{|c|}{ Panel C: 9-day Time Window } \\
\hline Mean & 2006.08 & 1261.76 & 1250.37 \\
\hline Std. Dev. & 954.46 & 485.81 & 649.77 \\
\hline Min & 0.00 & 0.00 & 0.00 \\
\hline Max & 66643.99 & 7549.47 & 9599.05 \\
\hline \multicolumn{4}{|c|}{ Panel D: 14-day Time Window } \\
\hline Mean & 3119.73 & 1963.07 & 1945.63 \\
\hline Std. Dev. & 1445.75 & 722.09 & 979.93 \\
\hline Min & 0.00 & 0.00 & 0.00 \\
\hline Max & 78278.62 & 10776.26 & 14186.20 \\
\hline \multicolumn{4}{|c|}{ Panel E: 21-day Time Window } \\
\hline Mean & 4677.94 & 2944.93 & 2919.29 \\
\hline Std. Dev. & 2125.54 & 1053.05 & 1441.61 \\
\hline Min & 0.00 & 0.00 & 0.00 \\
\hline Max & 86205.14 & 15220.70 & 20642.20 \\
\hline \multicolumn{4}{|c|}{ Panel F: 28-day Time Window } \\
\hline Mean & 6235.21 & 3926.76 & 3893.20 \\
\hline Std. Dev. & 2798.02 & 1382.92 & 1902.21 \\
\hline Min & 0.00 & 0.00 & 0.00 \\
\hline Max & 89607.08 & 19969.56 & 26333.67 \\
\hline
\end{tabular}

Notes: This table presents summary statistics of hospitalization rates (i.e., hospital visits per million residents) by time window following pollution exposure, including mean, standard deviation, minimum, and maximum. The data are obtained Office of Statewide Health Planning and Development of California. 
Table A.8: Summary statistics of hospitalization rate by data specification

\begin{tabular}{lccr}
\hline \hline & All & All & All \\
& Respiratory & Heart & Psychiatric \\
\hline Panel A: Principal Diagnosis & & & \\
Mean & 86.86 & 32.09 & 29.23 \\
Std. Dev. & 76.26 & 38.47 & 40.36 \\
Min & 0.00 & 0.00 & 0.00 \\
Max & 6089.47 & 728.97 & 999.29 \\
\hline Panel B: Patient Discharge Data (PDD) & & \\
Mean & 78.88 & 77.26 & 60.22 \\
Std. Dev. & 67.20 & 61.90 & 0.00 \\
Min & 0.00 & 0.00 & 1142.04 \\
Max & 2652.14 & 1231.35 & \\
\hline Panel C: Emergency Department Data (EDD) & & 68.94 \\
Mean & 127.12 & 46.38 & 72.42 \\
Std. Dev. & 112.51 & 49.86 & 0.00 \\
Min & 0.00 & 0.00 & 1190.12 \\
Max & 12519.14 & 791.48 & \\
\hline Panel D: Ambulatory Surgery Center Data (ASCD) & & 9.66 \\
Mean & 16.98 & 16.47 & 0.00 \\
Std. Dev. & 31.06 & 29.79 & 691.92 \\
Min & 0.00 & 691.92 & \\
Max & 785.24 & 090 & \\
\hline \hline
\end{tabular}

Notes: Table presents summary statistics of hospitalization rate in various data specifications, including mean, standard deviation, minimum, and maximum. Panels A-C show statistics for different OSHPD data sets. Panel D presents the statistics by only counting principal diagnoses (i.e., secondary diagnoses are excluded). The data are obtained Office of Statewide Health Planning and Development of California.

Table A.9: Average pollution exposure weighted by Black and white population in port areas

\begin{tabular}{lcc}
\hline \hline & Black & White \\
\hline $\mathrm{CO}(\mathrm{ppb})$ & 419.19 & 402.06 \\
$\mathrm{NO}_{2}(\mathrm{ppb})$ & 15.25 & 13.68 \\
$\mathrm{PM}_{2.5}\left(\mu \mathrm{g} / \mathrm{m}^{3}\right)$ & 10.54 & 10.02 \\
$\mathrm{SO}_{2}(\mathrm{ppb})$ & 0.61 & 0.58 \\
\hline \hline
\end{tabular}

Notes: This table presents average pollution exposure for Blacks and whites for 2010-2016, weighted by the zip code-level Black and white population. The population data are obtained from U.S. 2010 Decennial Census. The pollution data are from the U.S. EPA Air Quality System. 
Table A.10: Balance statistics for weather variables in port areas

\begin{tabular}{lccc}
\hline \hline & $\begin{array}{c}\text { Standardized } \\
\text { Mean Differences }\end{array}$ & $\begin{array}{c}\text { Variance } \\
\text { Ratio }\end{array}$ & $\begin{array}{c}\text { Kolmogorov-Smirnov } \\
\text { Statistics }\end{array}$ \\
\hline Wind Speed (m/s) & -0.012 & 1.070 & 0.019 \\
Wind Direction (degree) & -0.011 & 1.041 & 0.012 \\
Max Temperature (C) & 0.006 & 0.989 & 0.009 \\
Min Temperature (C) & -0.005 & 0.998 & 0.010 \\
Precipitation (mm) & -0.015 & 1.016 & 0.008 \\
Dew Point Temperature (C) & -0.015 & 0.985 & 0.014 \\
\hline \hline
\end{tabular}

Notes: This table presents the balance statistics of weather variables in the U.S. port areas, separately for the month-days when there exist seven-day lagged and 500-mile distant tropical cyclones in the ocean and the same month-days when there are no such cyclones. Balanced sub-samples indicate that standardized mean differences are close to zero, variance ratios are close to one, and Kolmogorov-Smirnov (KS) statistics are close to zero. The data are obtained from the NOAA Integrated Surface Database.

Table A.11: First-stage relationship between tropical cyclones and port traffic

\begin{tabular}{lcccc}
\hline \hline & \multicolumn{4}{c}{ Dependent variable: port traffic } \\
\cline { 2 - 5 } & $(1)$ & $(2)$ & $(3)$ & $(4)$ \\
\hline Panel A: Log of vessel tonnage & & & & \\
Tropical Cyclone & $-0.04^{* * *}$ & $-0.04^{* * *}$ & $-0.05^{* * *}$ & $-0.04^{* * *}$ \\
& $(0.01)$ & $(0.01)$ & $(0.01)$ & $(0.01)$ \\
\cline { 2 - 5 } First-Stage F Stat. & 32.88 & 37.42 & 36.52 & 30.89 \\
Anderson-Rubin Stat. P-val & 0.0021 & 0.0402 & 0.0080 & 0.0268 \\
Stock-Wright S Stat. P-val & 0.0012 & 0.0216 & 0.0066 & 0.0154 \\
Observations & 502,631 & 587,833 & 423,200 & 431,574 \\
\hline Panel B: Number of vessels & & & & \\
Tropical Cyclone & & & & $-0.45^{* * *}$ \\
& $-0.54^{* * *}$ & $-0.48^{* * *}$ & $-0.48^{* * *}$ & $(0.12)$ \\
First-Stage F Stat. & $(0.13)$ & $(0.10)$ & 13.64 \\
Anderson-Rubin Stat. P-val & 16.69 & 20.78 & 12.96 \\
Stock-Wright S Stat. P-val & 0.0021 & 0.0402 & 0.0080 & 0.0268 \\
Observations & 0.0012 & 0.0216 & 0.0066 & 0.0154 \\
\hline \hline
\end{tabular}

Notes: Panel A presents the first-stage results for the instrumental variable estimation in Panel A in Table 1, where the port traffic is measured as log of daily vessel tonnage. Panel B presents the the first-stage results for the instrumental variable estimation Panel B, using the number of vessels as the variable of interest. Each entry orresponds to an individual regression. The instrument is an indicator of seven-day lagged and 500-mile distant cyclones in the ocean. All regressions include weather controls, such as the quadratics of maximum temperature, minimum temperature, dew point temperature, precipitation, wind speed, and relative wind direction between a monitor-port pair. All regressions also include county-by-year, month, day-of-week, holiday, and monitor-port pair fixed effects. An observation is a monitor-port-day. Standard errors are clustered by monitor-port pair and day. Significance levels are indicated by $* * * 1 \%$, $* * 5$, and $* 10 \%$. 
Table A.12: 2SLS estimation of the effect of vessels in port on ozone pollution

\begin{tabular}{lc}
\hline \hline & \multicolumn{2}{c}{ Dependent variable: log of pollution concentration } \\
\cline { 2 - 2 } Panel A: Vessel tonnage & $\mathrm{O}_{3}$ \\
Log of Vessel Tonnage & $-0.39^{* *}$ \\
& $(0.17)$ \\
Adjusted $\mathrm{R}^{2}$ & 0.19 \\
Observations & 827,569 \\
\hline Panel B: Number of vessels & \\
Number of Vessels & $-0.042^{* *}$ \\
Adjusted $\mathrm{R}^{2}$ & $(0.019)$ \\
Observations & 0.27 \\
\hline \hline
\end{tabular}

Panel A presents the instrumental variable estimation of the effect of log vessel tonnage on air pollutant concentrations within a 25-mile radius of ports in the United States. Panel B presents the same instrumental variable estimation using the number of vessels in ports as the variable of interest. Each entry presents an individual regression on a local air pollutant. The endogenous variables, vessel tonnage and the number of vessels, are instrumented by an indicator of seven-day lagged cyclones that are at least 500-mile distant from ports. All regressions include weather controls, such as the quadratics of maximum, minimum, and dew point temperature, precipitation, wind speed, and relative wind direction between a monitor-port pair. All regressions also include county-by-year, month, day-of-week, holiday, and monitor-port fixed effects. An observation is a monitor-port-day. Standard errors are clustered by monitor-port pair and day. Significance levels are indicated by ${ }^{* * *} 1 \%,{ }^{* *} 5 \%$, and ${ }^{*} 10 \%$.

Table A.13: OLS estimation of the effect of vessel tonnage in port on air pollution

\begin{tabular}{lcccc}
\hline \hline & \multicolumn{4}{c}{ Dependent variable: log of pollution concentration } \\
\cline { 2 - 5 } & $\mathrm{CO}$ & $\mathrm{NO}_{2}$ & $\mathrm{PM}_{2.5}$ & $\mathrm{SO}_{2}$ \\
& $(1)$ & $(2)$ & $(3)$ & $(4)$ \\
\hline Log of Vessel Tonnage & 0.001 & $0.01^{* * *}$ & 0.01 & $0.01^{*}$ \\
& $(0.003)$ & $(0.004)$ & $(0.003)$ & $(0.01)$ \\
\hline Adjusted $\mathrm{R}^{2}$ & 0.57 & 0.75 & 0.46 & 0.50 \\
Observations & 502,631 & 587,833 & 423,200 & 431,574 \\
\hline \hline
\end{tabular}

Notes: This table presents the OLS estimation of the effect of vessel tonnage in port on air pollution. Each column presents an individual regression on a local air pollutant. All regressions include weather controls, such as the quadratics of maximum temperature, minimum temperature, dew point temperature, precipitation, wind speed, and relative wind direction between a monitor-port pair. All regressions also include county-byyear, month, day-of-week, holiday, and monitor-port pair fixed effects. An observation is a monitor-port-day. Standard errors are clustered by monitor-port pair and day. Significance levels are indicated by *** $1 \%$, ${ }^{* *} \%$, and * $10 \%$. 
Table A.14: Effect of air pollution on hospitalizaton rates for the overall population in California port areas, instrumental variable estimation

\begin{tabular}{|c|c|c|c|c|c|c|}
\hline & \multicolumn{6}{|c|}{ Dependent variable: hospital visits/million residents } \\
\hline & \multicolumn{3}{|c|}{ Respiratory } & \multirow{2}{*}{$\begin{array}{c}\text { Heart } \\
\text { All } \\
\text { Heart } \\
(4)\end{array}$} & \multicolumn{2}{|c|}{ Psychiatric } \\
\hline & $\begin{array}{c}\text { Asthma } \\
\text { (1) }\end{array}$ & $\begin{array}{c}\text { Upper } \\
\text { Respiratory } \\
(2)\end{array}$ & $\begin{array}{c}\text { All } \\
\text { Respiratory } \\
\text { (3) }\end{array}$ & & $\begin{array}{c}\text { Anxiety } \\
\text { (5) }\end{array}$ & $\begin{array}{c}\text { All } \\
\text { Psychiatric } \\
(6) \\
\end{array}$ \\
\hline \multicolumn{7}{|l|}{ Panel A: CO } \\
\hline $\mathrm{CO}(\mathrm{ppb})$ & $\begin{array}{l}0.01^{* * *} \\
(0.002)\end{array}$ & $\begin{array}{l}0.01^{* * *} \\
(0.003)\end{array}$ & $\begin{array}{l}0.05^{* * *} \\
(0.01) \\
\end{array}$ & $\begin{array}{l}0.01^{* * *} \\
(0.003) \\
\end{array}$ & $\begin{array}{l}0.003^{* * *} \\
(0.001) \\
\end{array}$ & $\begin{array}{l}0.01^{* * *} \\
(0.003)\end{array}$ \\
\hline $\begin{array}{l}\text { Adjusted } R^{2} \\
\text { First-stage F Stat. } \\
\text { Anderson-Rubin Stat. P-val } \\
\text { Stock-Wright S Stat. P-val } \\
\text { Observations }\end{array}$ & $\begin{array}{c}0.39 \\
57.71 \\
3.35 \mathrm{e}-10 \\
4.64 \mathrm{e}-06 \\
1,782,266\end{array}$ & $\begin{array}{c}0.34 \\
57.71 \\
3.35 \mathrm{e}-10 \\
4.64 \mathrm{e}-06 \\
1,782,266\end{array}$ & $\begin{array}{c}0.47 \\
57.71 \\
3.35 \mathrm{e}-10 \\
4.64 \mathrm{e}-06 \\
1,782,266\end{array}$ & $\begin{array}{c}0.35 \\
57.71 \\
3.35 \mathrm{e}-10 \\
4.64 \mathrm{e}-06 \\
1,782,266\end{array}$ & $\begin{array}{c}0.22 \\
57.71 \\
3.35 \mathrm{e}-10 \\
4.64 \mathrm{e}-06 \\
1,782,266\end{array}$ & $\begin{array}{c}0.40 \\
57.71 \\
3.35 \mathrm{e}-10 \\
4.64 \mathrm{e}-06 \\
1,782,266\end{array}$ \\
\hline \multicolumn{7}{|l|}{ Panel B: $\mathrm{NO}_{2}$} \\
\hline $\mathrm{NO}_{2}(\mathrm{ppb})$ & $\begin{array}{l}0.28^{* * *} \\
(0.05) \\
\end{array}$ & $\begin{array}{l}0.34^{* * *} \\
(0.07) \\
\end{array}$ & $\begin{array}{l}1.04^{* * *} \\
(0.19) \\
\end{array}$ & $\begin{array}{l}0.37^{* * *} \\
(0.07)\end{array}$ & $\begin{array}{l}0.09^{* * *} \\
(0.03)\end{array}$ & $\begin{array}{c}0.23^{* * *} \\
(0.07) \\
\end{array}$ \\
\hline $\begin{array}{l}\text { Adjusted } R^{2} \\
\text { First-stage F Stat. } \\
\text { Anderson-Rubin Stat. P-val } \\
\text { Stock-Wright S Stat. P-val } \\
\text { Observations }\end{array}$ & $\begin{array}{c}0.39 \\
78.53 \\
2.75 \mathrm{e}-09 \\
1.50 \mathrm{e}-05 \\
1,812,210\end{array}$ & $\begin{array}{c}0.33 \\
78.53 \\
2.75 \mathrm{e}-09 \\
1.50 \mathrm{e}-05 \\
1,812,210\end{array}$ & $\begin{array}{c}0.47 \\
78.53 \\
2.75 \mathrm{e}-09 \\
1.50 \mathrm{e}-05 \\
1,812,210\end{array}$ & $\begin{array}{c}0.35 \\
78.53 \\
2.75 \mathrm{e}-09 \\
1.50 \mathrm{e}-05 \\
1,812,210\end{array}$ & $\begin{array}{c}0.22 \\
78.53 \\
2.75 \mathrm{e}-09 \\
1.50 \mathrm{e}-05 \\
1,812,210\end{array}$ & $\begin{array}{c}0.40 \\
78.53 \\
2.75 \mathrm{e}-09 \\
1.50 \mathrm{e}-05 \\
1,812,210\end{array}$ \\
\hline \multicolumn{7}{|l|}{ Panel C: $\mathbf{P M}_{2.5}$} \\
\hline $\mathrm{PM}_{2.5}\left(\mu \mathrm{g} / \mathrm{m}^{3}\right)$ & $\begin{array}{l}0.35^{* * *} \\
(0.06)\end{array}$ & $\begin{array}{l}0.42^{* * *} \\
(0.10)\end{array}$ & $\begin{array}{l}1.28^{* * *} \\
(0.26)\end{array}$ & $\begin{array}{l}0.43^{* * *} \\
(0.09)\end{array}$ & $\begin{array}{l}0.10^{* *} \\
(0.04)\end{array}$ & $\begin{array}{l}0.26^{* * *} \\
(0.09)\end{array}$ \\
\hline $\begin{array}{l}\text { Adjusted } R^{2} \\
\text { First-stage F Stat. } \\
\text { Anderson-Rubin Stat. P-val } \\
\text { Stock-Wright S Stat. P-val } \\
\text { Observations }\end{array}$ & $\begin{array}{c}0.39 \\
28.42 \\
5.12 \mathrm{e}-09 \\
1.99 \mathrm{e}-05 \\
1,720,810\end{array}$ & $\begin{array}{c}0.34 \\
28.42 \\
5.12 \mathrm{e}-09 \\
1.99 \mathrm{e}-05 \\
1,720,810\end{array}$ & $\begin{array}{c}0.47 \\
28.42 \\
5.12 \mathrm{e}-09 \\
1.99 \mathrm{e}-05 \\
1,720,810\end{array}$ & $\begin{array}{c}0.35 \\
28.42 \\
5.12 \mathrm{e}-09 \\
1.99 \mathrm{e}-05 \\
1,720,810\end{array}$ & $\begin{array}{c}0.22 \\
28.42 \\
5.12 \mathrm{e}-09 \\
1.99 \mathrm{e}-05 \\
1,720,810\end{array}$ & $\begin{array}{c}0.40 \\
28.42 \\
5.12 \mathrm{e}-09 \\
1.99 \mathrm{e}-05 \\
1,720,810\end{array}$ \\
\hline \multicolumn{7}{|l|}{ Panel D: $\mathrm{SO}_{2}$} \\
\hline $\mathrm{SO}_{2}(\mathrm{ppb})$ & $\begin{array}{l}7.36^{* * *} \\
(1.36)\end{array}$ & $\begin{array}{l}9.25^{* * *} \\
(2.11)\end{array}$ & $\begin{array}{c}27.47^{* * *} \\
(5.57)\end{array}$ & $\begin{array}{l}9.99^{* * *} \\
(1.98)\end{array}$ & $\begin{array}{l}2.68^{* * *} \\
(0.85)\end{array}$ & $\begin{array}{l}6.95^{* * *} \\
(2.04)\end{array}$ \\
\hline Adjusted $R^{2}$ & 0.39 & 0.33 & 0.47 & 0.35 & 0.22 & 0.40 \\
\hline First-stage F Stat. & 29.97 & 29.97 & 29.97 & 29.97 & 29.97 & 29.97 \\
\hline Anderson-Rubin Stat. P-val & $4.80 \mathrm{e}-10$ & $4.80 \mathrm{e}-10$ & $4.80 \mathrm{e}-10$ & $4.80 \mathrm{e}-10$ & $4.80 \mathrm{e}-10$ & $4.80 \mathrm{e}-10$ \\
\hline Stock-Wright S Stat. P-val & $6.13 \mathrm{e}-06$ & $6.13 \mathrm{e}-06$ & $6.13 \mathrm{e}-06$ & $6.13 \mathrm{e}-06$ & $6.13 \mathrm{e}-06$ & $6.13 \mathrm{e}-06$ \\
\hline Observations & $1,749,073$ & $1,749,073$ & $1,749,073$ & $1,749,073$ & $1,749,073$ & $1,749,073$ \\
\hline
\end{tabular}

Notes: This table presents the detailed results of Panel A in Table 2. Each entry presents an individual regression of an air pollutant on an illness category. Pollution concentrations are instrumented by fitted vessel tonnage in ports, wind direction, wind speed, and their interactions. All regressions include weather controls, such as the quadratics of maximum, minimum, and dew point temperature, and precipitation. All regressions also include county-by-year, month, day-of-week, holiday, and zip code-port pair fixed effects. An observation is a zip code-port-day. Standard errors are clustered by zip code-port pair and day. Estimates are weighted by the zip code-specific population. Significance levels are indicated by ${ }^{* * *} 1 \%, * * 5 \%$, and * $10 \%$. 
Table A.15: Effect of air pollution on hospitalizaton rates for Blacks in California port areas, instrumental variable estimation

\begin{tabular}{|c|c|c|c|c|c|c|}
\hline & \multicolumn{6}{|c|}{ Dependent variable: hospital visits/million residents } \\
\hline & \multicolumn{3}{|c|}{ Respiratory } & \multirow{2}{*}{$\begin{array}{c}\text { Heart } \\
\text { All } \\
\text { Heart } \\
(4)\end{array}$} & \multicolumn{2}{|c|}{ Psychiatric } \\
\hline & $\begin{array}{c}\text { Asthma } \\
\text { (1) }\end{array}$ & $\begin{array}{c}\text { Upper } \\
\text { Respiratory } \\
(2)\end{array}$ & $\begin{array}{c}\text { All } \\
\text { Respiratory } \\
\text { (3) }\end{array}$ & & $\begin{array}{c}\text { Anxiety } \\
\text { (5) }\end{array}$ & $\begin{array}{c}\text { All } \\
\text { Psychiatric } \\
(6) \\
\end{array}$ \\
\hline \multicolumn{7}{|l|}{ Panel A: CO } \\
\hline $\mathrm{CO}(\mathrm{ppb})$ & $\begin{array}{l}0.04^{* * *} \\
(0.01)\end{array}$ & $\begin{array}{l}0.03^{* * *} \\
(0.01)\end{array}$ & $\begin{array}{l}0.09^{* * *} \\
(0.02)\end{array}$ & $\begin{array}{l}0.03^{* * *} \\
(0.01)\end{array}$ & $\begin{array}{c}0.004 \\
(0.004)\end{array}$ & $\begin{array}{c}-0.0001 \\
(0.01)\end{array}$ \\
\hline $\begin{array}{l}\text { Adjusted } R^{2} \\
\text { First-stage F Stat. } \\
\text { Anderson-Rubin Stat. P-val } \\
\text { Stock-Wright S Stat. P-val } \\
\text { Observations }\end{array}$ & $\begin{array}{c}0.17 \\
46.66 \\
0 \\
0.000400 \\
877,508\end{array}$ & $\begin{array}{c}0.10 \\
46.66 \\
0 \\
0.000400 \\
877,508\end{array}$ & $\begin{array}{c}0.23 \\
46.66 \\
0 \\
0.000400 \\
877,508\end{array}$ & $\begin{array}{c}0.13 \\
46.66 \\
0 \\
0.000400 \\
877,508\end{array}$ & $\begin{array}{c}0.05 \\
46.66 \\
0 \\
0.000400 \\
877,508\end{array}$ & $\begin{array}{c}0.19 \\
46.66 \\
0 \\
0.000400 \\
877,508\end{array}$ \\
\hline \multicolumn{7}{|l|}{ Panel B: $\mathrm{NO}_{2}$} \\
\hline $\mathrm{NO}_{2}(\mathrm{ppb})$ & $\begin{array}{l}0.83^{* * *} \\
(0.20)\end{array}$ & $\begin{array}{l}1.03^{* * *} \\
(0.17)\end{array}$ & $\begin{array}{l}2.73^{* * *} \\
(0.50)\end{array}$ & $\begin{array}{l}0.71^{* * *} \\
(0.22)\end{array}$ & $\begin{array}{c}0.14 \\
(0.10) \\
\end{array}$ & $\begin{array}{c}0.08 \\
(0.23) \\
\end{array}$ \\
\hline $\begin{array}{l}\text { Adjusted } R^{2} \\
\text { First-stage F Stat. } \\
\text { Anderson-Rubin Stat. P-val } \\
\text { Stock-Wright S Stat. P-val } \\
\text { Observations }\end{array}$ & $\begin{array}{c}0.17 \\
61.27 \\
5.31 \mathrm{e}-11 \\
0.000385 \\
888,231\end{array}$ & $\begin{array}{c}0.10 \\
61.27 \\
5.31 \mathrm{e}-11 \\
0.000385 \\
888,231\end{array}$ & $\begin{array}{c}0.23 \\
61.27 \\
5.31 \mathrm{e}-11 \\
0.000385 \\
888,231\end{array}$ & $\begin{array}{c}0.13 \\
61.27 \\
5.31 \mathrm{e}-11 \\
0.000385 \\
888,231\end{array}$ & $\begin{array}{c}0.05 \\
61.27 \\
5.31 \mathrm{e}-11 \\
0.000385 \\
888,231\end{array}$ & $\begin{array}{c}0.19 \\
61.27 \\
5.31 \mathrm{e}-11 \\
0.000385 \\
888,231\end{array}$ \\
\hline \multicolumn{7}{|l|}{ Panel C: $\mathbf{P M}_{2.5}$} \\
\hline $\mathrm{PM}_{2.5}\left(\mu \mathrm{g} / \mathrm{m}^{3}\right)$ & $\begin{array}{l}1.07^{* * *} \\
(0.24)\end{array}$ & $\begin{array}{l}1.22^{* * *} \\
(0.22)\end{array}$ & $\begin{array}{l}3.45^{* * *} \\
(0.62)\end{array}$ & $\begin{array}{l}0.73^{* * *} \\
(0.27)\end{array}$ & $\begin{array}{c}0.07 \\
(0.12)\end{array}$ & $\begin{array}{l}-0.09 \\
(0.28)\end{array}$ \\
\hline $\begin{array}{l}\text { Adjusted } R^{2} \\
\text { First-stage F Stat. } \\
\text { Anderson-Rubin Stat. P-val } \\
\text { Stock-Wright S Stat. P-val } \\
\text { Observations }\end{array}$ & $\begin{array}{c}0.17 \\
24.07 \\
4.35 \mathrm{e}-10 \\
0.000605 \\
847,682\end{array}$ & $\begin{array}{c}0.10 \\
24.07 \\
4.35 \mathrm{e}-10 \\
0.000605 \\
847,682\end{array}$ & $\begin{array}{c}0.23 \\
24.07 \\
4.35 \mathrm{e}-10 \\
0.000605 \\
847,682\end{array}$ & $\begin{array}{c}0.13 \\
24.07 \\
4.35 \mathrm{e}-10 \\
0.000605 \\
847,682\end{array}$ & $\begin{array}{c}0.05 \\
24.07 \\
4.35 \mathrm{e}-10 \\
0.000605 \\
847,682\end{array}$ & $\begin{array}{c}0.19 \\
24.07 \\
4.35 \mathrm{e}-10 \\
0.000605 \\
847,682\end{array}$ \\
\hline \multicolumn{7}{|l|}{ Panel D: $\mathrm{SO}_{2}$} \\
\hline $\mathrm{SO}_{2}(\mathrm{ppb})$ & $\begin{array}{c}23.44^{* * *} \\
(5.28)\end{array}$ & $\begin{array}{c}35.53^{* * *} \\
(5.13)\end{array}$ & $\begin{array}{c}85.74^{* * *} \\
(14.16)\end{array}$ & $\begin{array}{c}17.99^{* * *} \\
(6.11)\end{array}$ & $\begin{array}{c}4.50 \\
(2.80)\end{array}$ & $\begin{array}{c}4.55 \\
(6.34)\end{array}$ \\
\hline Adjusted $\mathrm{R}^{2}$ & 0.17 & 0.10 & 0.23 & 0.13 & 0.05 & 0.19 \\
\hline First-stage F Stat. & 20.99 & 20.99 & 20.99 & 20.99 & 20.99 & 20.99 \\
\hline Anderson-Rubin Stat. P-val & 0 & 0 & 0 & 0 & 0 & 0 \\
\hline Stock-Wright S Stat. P-val & 0.000331 & 0.000331 & 0.000331 & 0.000331 & 0.000331 & 0.000331 \\
\hline Observations & 872,257 & 872,257 & 872,257 & 872,257 & 872,257 & 872,257 \\
\hline
\end{tabular}

Notes: This table presents the detailed results of Panel B in Table 2. Each entry presents an individual regression of an air pollutant on an illness category. Pollution concentrations are instrumented by fitted vessel tonnage in ports, wind direction, wind speed, and their interactions. All regressions include weather controls, such as the quadratics of maximum, minimum, and dew point temperature, and precipitation. All regressions also include county-by-year, month, day-of-week, holiday, and zip code-port pair fixed effects. An observation is a zip code-port-day. Standard errors are clustered by zip code-port pair and day. Estimates are weighted by the zip code-specific population. Significance levels are indicated by ${ }^{* *} 1 \%,{ }^{* *} 5 \%$, and ${ }^{*} 10 \%$. 
Table A.16: Effect of air pollution on hospitalizaton rates for whites in California port areas, instrumental variable estimation

\begin{tabular}{|c|c|c|c|c|c|c|}
\hline & \multicolumn{6}{|c|}{ Dependent variable: hospital visits/million residents } \\
\hline & \multicolumn{3}{|c|}{ Respiratory } & \multirow{2}{*}{$\begin{array}{c}\text { Heart } \\
\text { All } \\
\text { Heart } \\
(4)\end{array}$} & \multicolumn{2}{|c|}{ Psychiatric } \\
\hline & $\begin{array}{c}\text { Asthma } \\
\text { (1) }\end{array}$ & $\begin{array}{c}\text { Upper } \\
\text { Respiratory } \\
(2)\end{array}$ & $\begin{array}{c}\text { All } \\
\text { Respiratory } \\
(3)\end{array}$ & & $\begin{array}{c}\text { Anxiety } \\
\text { (5) }\end{array}$ & $\begin{array}{c}\text { All } \\
\text { Psychiatric } \\
(6) \\
\end{array}$ \\
\hline \multicolumn{7}{|l|}{ Panel A: CO } \\
\hline $\mathrm{CO}(\mathrm{ppb})$ & $\begin{array}{l}0.01^{* * *} \\
(0.002) \\
\end{array}$ & $\begin{array}{l}0.01^{* * *} \\
(0.002) \\
\end{array}$ & $\begin{array}{l}0.04^{* * *} \\
(0.01) \\
\end{array}$ & $\begin{array}{l}0.02^{* * *} \\
(0.01)\end{array}$ & $\begin{array}{c}0.001 \\
(0.002) \\
\end{array}$ & $\begin{array}{l}0.01^{* *} \\
(0.01) \\
\end{array}$ \\
\hline $\begin{array}{l}\text { Adjusted } R^{2} \\
\text { First-stage F Stat. } \\
\text { Anderson-Rubin Stat. P-val } \\
\text { Stock-Wright S Stat. P-val } \\
\text { Observations }\end{array}$ & $\begin{array}{c}0.17 \\
59.79 \\
6.28 \mathrm{e}-10 \\
7.37 \mathrm{e}-06 \\
1,657,238\end{array}$ & $\begin{array}{c}0.09 \\
59.79 \\
6.28 \mathrm{e}-10 \\
7.37 \mathrm{e}-06 \\
1,657,238\end{array}$ & $\begin{array}{c}0.34 \\
59.79 \\
6.28 \mathrm{e}-10 \\
7.37 \mathrm{e}-06 \\
1,657,238\end{array}$ & $\begin{array}{c}0.28 \\
59.79 \\
6.28 \mathrm{e}-10 \\
7.37 \mathrm{e}-06 \\
1,657,238\end{array}$ & $\begin{array}{c}0.15 \\
59.79 \\
6.28 \mathrm{e}-10 \\
7.37 \mathrm{e}-06 \\
1,657,238\end{array}$ & $\begin{array}{c}0.32 \\
59.79 \\
6.28 \mathrm{e}-10 \\
7.37 \mathrm{e}-06 \\
1,657,238\end{array}$ \\
\hline \multicolumn{7}{|l|}{ Panel B: $\mathrm{NO}_{2}$} \\
\hline $\mathrm{NO}_{2}(\mathrm{ppb})$ & $\begin{array}{l}0.21^{* * *} \\
(0.05)\end{array}$ & $\begin{array}{l}0.21^{* * *} \\
(0.05)\end{array}$ & $\begin{array}{l}0.80^{* * *} \\
(0.17)\end{array}$ & $\begin{array}{l}0.42^{* * *} \\
(0.12)\end{array}$ & $\begin{array}{c}0.03 \\
(0.06)\end{array}$ & $\begin{array}{l}0.29^{* *} \\
(0.13)\end{array}$ \\
\hline $\begin{array}{l}\text { Adjusted } R^{2} \\
\text { First-stage F Stat. } \\
\text { Anderson-Rubin Stat. P-val } \\
\text { Stock-Wright S Stat. P-val } \\
\text { Observations }\end{array}$ & $\begin{array}{c}0.17 \\
82.91 \\
1.73 \mathrm{e}-08 \\
3.15 \mathrm{e}-05 \\
1,687,158\end{array}$ & $\begin{array}{c}0.09 \\
82.91 \\
1.73 \mathrm{e}-08 \\
3.15 \mathrm{e}-05 \\
1,687,158\end{array}$ & $\begin{array}{c}0.34 \\
82.91 \\
1.73 \mathrm{e}-08 \\
3.15 \mathrm{e}-05 \\
1,687,158\end{array}$ & $\begin{array}{c}0.28 \\
82.91 \\
1.73 \mathrm{e}-08 \\
3.15 \mathrm{e}-05 \\
1,687,158\end{array}$ & $\begin{array}{c}0.15 \\
82.91 \\
1.73 \mathrm{e}-08 \\
3.15 \mathrm{e}-05 \\
1,687,158\end{array}$ & $\begin{array}{c}0.32 \\
82.91 \\
1.73 \mathrm{e}-08 \\
3.15 \mathrm{e}-05 \\
1,687,158\end{array}$ \\
\hline \multicolumn{7}{|l|}{ Panel C: $\mathbf{P M}_{2.5}$} \\
\hline $\mathrm{PM}_{2.5}\left(\mu \mathrm{g} / \mathrm{m}^{3}\right)$ & $\begin{array}{l}0.29^{* * *} \\
(0.08)\end{array}$ & $\begin{array}{l}0.28^{* * *} \\
(0.07)\end{array}$ & $\begin{array}{l}1.04^{* * *} \\
(0.24)\end{array}$ & $\begin{array}{l}0.55^{* * *} \\
(0.17)\end{array}$ & $\begin{array}{c}0.05 \\
(0.08)\end{array}$ & $\begin{array}{l}0.37^{* *} \\
(0.19)\end{array}$ \\
\hline $\begin{array}{l}\text { Adjusted } R^{2} \\
\text { First-stage F Stat. } \\
\text { Anderson-Rubin Stat. P-val } \\
\text { Stock-Wright S Stat. P-val } \\
\text { Observations }\end{array}$ & $\begin{array}{c}0.17 \\
27.86 \\
2.33 \mathrm{e}-08 \\
3.70 \mathrm{e}-05 \\
1,605,247\end{array}$ & $\begin{array}{c}0.09 \\
27.86 \\
2.33 \mathrm{e}-08 \\
3.70 \mathrm{e}-05 \\
1,605,247\end{array}$ & $\begin{array}{c}0.34 \\
27.86 \\
2.33 \mathrm{e}-08 \\
3.70 \mathrm{e}-05 \\
1,605,247\end{array}$ & $\begin{array}{c}0.28 \\
27.86 \\
2.33 \mathrm{e}-08 \\
3.70 \mathrm{e}-05 \\
1,605,247\end{array}$ & $\begin{array}{c}0.15 \\
27.86 \\
2.33 \mathrm{e}-08 \\
3.70 \mathrm{e}-05 \\
1,605,247\end{array}$ & $\begin{array}{c}0.32 \\
27.86 \\
2.33 \mathrm{e}-08 \\
3.70 \mathrm{e}-05 \\
1,605,247\end{array}$ \\
\hline \multicolumn{7}{|l|}{ Panel D: $\mathrm{SO}_{2}$} \\
\hline $\mathrm{SO}_{2}(\mathrm{ppb})$ & $\begin{array}{l}4.68^{* * *} \\
(1.47)\end{array}$ & $\begin{array}{l}5.23^{* * *} \\
(1.24)\end{array}$ & $\begin{array}{c}18.26^{* * *} \\
(4.48)\end{array}$ & $\begin{array}{c}10.01^{* * *} \\
(3.17)\end{array}$ & $\begin{array}{c}1.22 \\
(1.46)\end{array}$ & $\begin{array}{l}8.12^{* *} \\
(3.43)\end{array}$ \\
\hline Adjusted $R^{2}$ & 0.17 & 0.09 & 0.33 & 0.28 & 0.15 & 0.32 \\
\hline First-stage F Stat. & 34.08 & 34.08 & 34.08 & 34.08 & 34.08 & 34.08 \\
\hline Anderson-Rubin Stat. P-val & $8.89 \mathrm{e}-10$ & $8.89 \mathrm{e}-10$ & $8.89 \mathrm{e}-10$ & $8.89 \mathrm{e}-10$ & $8.89 \mathrm{e}-10$ & $8.89 \mathrm{e}-10$ \\
\hline Stock-Wright S Stat. P-val & $9.39 \mathrm{e}-06$ & $9.39 \mathrm{e}-06$ & $9.39 \mathrm{e}-06$ & $9.39 \mathrm{e}-06$ & $9.39 \mathrm{e}-06$ & $9.39 \mathrm{e}-06$ \\
\hline Observations & $1,624,191$ & $1,624,191$ & $1,624,191$ & $1,624,191$ & $1,624,191$ & $1,624,191$ \\
\hline
\end{tabular}

Notes: This table presents the detailed results of Panel C in Table 2. Each entry presents an individual regression of an air pollutant on an illness category. Pollution concentrations are instrumented by fitted vessel tonnage in ports, wind direction, wind speed, and their interactions. All regressions include weather controls, such as the quadratics of maximum, minimum, and dew point temperature, and precipitation. All regressions also include county-by-year, month, day-of-week, holiday, and zip code-port pair fixed effects. An observation is a zip code-port-day. Standard errors are clustered by zip code-port pair and day. Estimates are weighted by the zip code-specific population. Significance levels are indicated by $* * 1 \%, * * 5 \%$, and * $10 \%$. 
Table A.17: OLS estimates of the effect of air pollution on hospitalizaton rates in California port areas

\begin{tabular}{|c|c|c|c|c|c|c|}
\hline & \multicolumn{6}{|c|}{ Dependent variable: hospital visits/million residents } \\
\hline & \multicolumn{3}{|c|}{ Respiratory } & \multirow{2}{*}{$\begin{array}{c}\text { Heart } \\
\text { All } \\
\text { Heart } \\
(4)\end{array}$} & \multicolumn{2}{|c|}{ Psychiatric } \\
\hline & $\begin{array}{c}\text { Asthma } \\
(1)\end{array}$ & $\begin{array}{c}\text { Upper } \\
\text { Respiratory } \\
(2) \\
\end{array}$ & $\begin{array}{c}\text { All } \\
\text { Respiratory } \\
\text { (3) }\end{array}$ & & $\begin{array}{c}\text { Anxiety } \\
(5)\end{array}$ & $\begin{array}{c}\text { All } \\
\text { Psychiatric } \\
(6)\end{array}$ \\
\hline \multicolumn{7}{|c|}{ Panel A: Overall population } \\
\hline $\mathrm{CO}(\mathrm{ppb})$ & $\begin{array}{l}0.005^{* * *} \\
(0.001)\end{array}$ & $\begin{array}{c}0.003 \\
(0.002)\end{array}$ & $\begin{array}{l}0.02^{* * *} \\
(0.004)\end{array}$ & $\begin{array}{l}0.01^{* * *} \\
(0.001)\end{array}$ & $\begin{array}{l}0.0004 \\
(0.001)\end{array}$ & $\begin{array}{c}0.002 \\
(0.002)\end{array}$ \\
\hline $\mathrm{NO}_{2}(\mathrm{ppb})$ & $\begin{array}{l}0.15^{* * *} \\
(0.03)\end{array}$ & $\begin{array}{c}-0.0003 \\
(0.05)\end{array}$ & $\begin{array}{l}0.50^{* * *} \\
(0.12)\end{array}$ & $\begin{array}{l}0.38^{* * *} \\
(0.05)\end{array}$ & $\begin{array}{l}0.07^{* * *} \\
(0.02)\end{array}$ & $\begin{array}{l}0.25^{* * *} \\
(0.05)\end{array}$ \\
\hline $\mathrm{PM}_{2.5}\left(\mu \mathrm{g} / \mathrm{m}^{3}\right)$ & $\begin{array}{l}0.08^{* * *} \\
(0.02)\end{array}$ & $\begin{array}{c}0.06 \\
(0.04)\end{array}$ & $\begin{array}{l}0.23^{* *} \\
(0.10)\end{array}$ & $\begin{array}{l}-0.03 \\
(0.04)\end{array}$ & $\begin{array}{l}0.004 \\
(0.02)\end{array}$ & $\begin{array}{l}0.004 \\
(0.04)\end{array}$ \\
\hline $\mathrm{SO}_{2}(\mathrm{ppb})$ & $\begin{array}{l}1.31^{* * *} \\
(0.29)\end{array}$ & $\begin{array}{l}-0.94^{* *} \\
(0.38)\end{array}$ & $\begin{array}{l}-0.66 \\
(1.06)\end{array}$ & $\begin{array}{l}0.96^{* *} \\
(0.39)\end{array}$ & $\begin{array}{l}0.36^{*} \\
(0.18)\end{array}$ & $\begin{array}{l}0.93^{* *} \\
(0.45)\end{array}$ \\
\hline \multicolumn{7}{|l|}{ Panel B: Black } \\
\hline $\mathrm{CO}(\mathrm{ppb})$ & $\begin{array}{l}0.01^{* * *} \\
(0.004)\end{array}$ & $\begin{array}{l}-0.004 \\
(0.004)\end{array}$ & $\begin{array}{l}0.03^{* *} \\
(0.01)\end{array}$ & $\begin{array}{l}0.01^{* * *} \\
(0.004)\end{array}$ & $\begin{array}{c}0.002 \\
(0.002)\end{array}$ & $\begin{array}{c}0.01^{*} \\
(0.004)\end{array}$ \\
\hline $\mathrm{NO}_{2}(\mathrm{ppb})$ & $\begin{array}{l}0.46^{* * *} \\
(0.13)\end{array}$ & $\begin{array}{c}0.02 \\
(0.11)\end{array}$ & $\begin{array}{l}1.23^{* * *} \\
(0.32)\end{array}$ & $\begin{array}{l}0.58^{* * * *} \\
(0.14)\end{array}$ & $\begin{array}{l}0.18^{* * *} \\
(0.06)\end{array}$ & $\begin{array}{l}0.54^{* * *} \\
(0.14)\end{array}$ \\
\hline $\mathrm{PM}_{2.5}\left(\mu \mathrm{g} / \mathrm{m}^{3}\right)$ & $\begin{array}{l}0.32^{* * *} \\
(0.10)\end{array}$ & $\begin{array}{l}-0.05 \\
(0.09)\end{array}$ & $\begin{array}{c}0.38 \\
(0.26)\end{array}$ & $\begin{array}{c}(0.01 \\
0.01 \\
(0.11)\end{array}$ & $\begin{array}{c}0.05 \\
(0.05)\end{array}$ & $\begin{array}{l}(0.02 \\
0.02 \\
(0.11)\end{array}$ \\
\hline $\mathrm{SO}_{2}(\mathrm{ppb})$ & $\begin{array}{l}6.74^{* * *} \\
(1.60)\end{array}$ & $\begin{array}{l}-0.17 \\
(1.32)\end{array}$ & $\begin{array}{l}6.37^{*} \\
(3.82)\end{array}$ & $\begin{array}{c}1.29 \\
(1.37)\end{array}$ & $\begin{array}{l}-0.25 \\
(0.60)\end{array}$ & $\begin{array}{c}1.48 \\
(1.56)\end{array}$ \\
\hline \multicolumn{7}{|l|}{ Panel C: White } \\
\hline $\mathrm{CO}(\mathrm{ppb})$ & $\begin{array}{l}0.00^{* * *} \\
(0.001)\end{array}$ & $\begin{array}{l}0.0000 \\
(0.001)\end{array}$ & $\begin{array}{l}0.02^{* * *} \\
(0.004)\end{array}$ & $\begin{array}{l}0.02^{* * *} \\
(0.002)\end{array}$ & $\begin{array}{c}0.002 \\
(0.001)\end{array}$ & $\begin{array}{l}0.01^{* *} \\
(0.003)\end{array}$ \\
\hline $\mathrm{NO}_{2}(\mathrm{ppb})$ & $\begin{array}{l}0.24^{* * *} \\
(0.04)\end{array}$ & $\begin{array}{l}-0.02 \\
(0.03)\end{array}$ & $\begin{array}{l}0.84^{* * *} \\
(0.11)\end{array}$ & $\begin{array}{l}0.80^{* * *} \\
(0.09)\end{array}$ & $\begin{array}{l}0.18^{* * *} \\
(0.03)\end{array}$ & $\begin{array}{l}0.59^{* * *} \\
(0.09)\end{array}$ \\
\hline $\mathrm{PM}_{2.5}\left(\mu \mathrm{g} / \mathrm{m}^{3}\right)$ & $\begin{array}{l}0.05 \\
(0.03)\end{array}$ & $\begin{array}{l}0.005 \\
(0.02)\end{array}$ & $\begin{array}{c}0.10 \\
(0.08)\end{array}$ & $\begin{array}{l}-0.04 \\
(0.07)\end{array}$ & $\begin{array}{l}0.002 \\
(0.03)\end{array}$ & $\begin{array}{c}0.03 \\
(0.07)\end{array}$ \\
\hline $\mathrm{SO}_{2}(\mathrm{ppb})$ & $\begin{array}{l}1.24^{* * *} \\
(0.34)\end{array}$ & $\begin{array}{l}-0.60^{* *} \\
(0.23)\end{array}$ & $\begin{array}{c}0.31 \\
(0.87)\end{array}$ & $\begin{array}{l}1.58^{* *} \\
(0.70)\end{array}$ & $\begin{array}{c}0.21 \\
(0.33)\end{array}$ & $\begin{array}{l}1.00 \\
(0.75)\end{array}$ \\
\hline
\end{tabular}

Notes: This table presents the OLS estimation of the effect of air pollution on hospitalization rates for the overall population, Blacks, and whites. Each entry presents an individual regression of an air pollutant on an illness category. All regressions include weather controls, such as the quadratics of maximum temperature, minimum temperature, dew point temperature, precipitation, wind speed, and relative wind direction between a zip code-port pair. All regressions also include county-by-year, month, day-of-week, holiday, and zip code-port pair fixed effects. An observation is a zip code-port-day. Standard errors are clustered by zip code-port pair and day. Estimates are weighted by the zip code-specific population. Significance levels are indicated by ** $1 \%$, $* * 5$, and * $10 \%$. 
Table A.18: Effect of air pollution on differences of hospitalizaton rates between Blacks and whites in California port areas, instrumental variable estimation

\begin{tabular}{|c|c|c|c|c|c|c|}
\hline & \multicolumn{6}{|c|}{ Dependent variable: hospitalization rate for Blacks - hospitalization rate for whites } \\
\hline & \multicolumn{3}{|c|}{ Respiratory } & \multirow{2}{*}{$\begin{array}{c}\text { Heart } \\
\text { All } \\
\text { Heart } \\
(4)\end{array}$} & \multicolumn{2}{|c|}{ Psychiatric } \\
\hline & $\begin{array}{l}\text { Asthma } \\
\text { (1) }\end{array}$ & $\begin{array}{c}\text { Upper } \\
\text { Respiratory } \\
\text { (2) }\end{array}$ & $\begin{array}{c}\text { All } \\
\text { Respiratory } \\
\text { (3) }\end{array}$ & & $\begin{array}{c}\text { Anxiety } \\
\text { (5) }\end{array}$ & $\begin{array}{c}\text { All } \\
\text { Psychiatric } \\
\text { (6) }\end{array}$ \\
\hline $\mathrm{CO}(\mathrm{ppb})$ & $\begin{array}{l}0.03^{* *} \\
(0.01)\end{array}$ & $\begin{array}{l}0.03^{* * *} \\
(0.01)\end{array}$ & $\begin{array}{l}0.05^{* *} \\
(0.02)\end{array}$ & $\begin{array}{l}-0.004 \\
(0.01)\end{array}$ & $\begin{array}{l}-0.002 \\
(0.01)\end{array}$ & $\begin{array}{l}-0.03 \\
(0.02)\end{array}$ \\
\hline $\mathrm{NO}_{2}(\mathrm{ppb})$ & $\begin{array}{l}0.74^{* * *} \\
(0.28)\end{array}$ & $\begin{array}{l}1.08^{* * *} \\
(0.20)\end{array}$ & $\begin{array}{c}2.05^{* * *} \\
(0.58)\end{array}$ & $\begin{array}{l}-0.09 \\
(0.34)\end{array}$ & $\begin{array}{l}-0.07 \\
(0.20)\end{array}$ & $\begin{array}{l}-0.62 \\
(0.43)\end{array}$ \\
\hline $\mathrm{PM}_{2.5}\left(\mu \mathrm{g} / \mathrm{m}^{3}\right)$ & $\begin{array}{l}0.95^{* *} \\
(0.37)\end{array}$ & $\begin{array}{l}1.29^{* * *} \\
(0.28)\end{array}$ & $\begin{array}{l}2.59^{* * *} \\
(0.78)\end{array}$ & $\begin{array}{l}-0.26 \\
(0.43)\end{array}$ & $\begin{array}{l}-0.13 \\
(0.26)\end{array}$ & $\begin{array}{l}-0.93 \\
(0.58)\end{array}$ \\
\hline $\mathrm{SO}_{2}(\mathrm{ppb})$ & $\begin{array}{l}21.41^{* * * *} \\
(6.88)\end{array}$ & $\begin{array}{c}32.06^{* * * *} \\
(5.41)\end{array}$ & $\begin{array}{l}67.07^{* * * *} \\
(15.07)\end{array}$ & $\begin{array}{l}-0.32 \\
(8.52)\end{array}$ & $\begin{array}{l}-1.49 \\
(4.88)\end{array}$ & $\begin{array}{l}-12.08 \\
(10.15)\end{array}$ \\
\hline
\end{tabular}

Notes: This table presents the effects of pollution on the differences of hospitalizaton rates between Blacks and whites. Each entry presents an individual regression of an air pollutant on an illness category. Pollution concentrations are instrumented by fitted vessel tonnage in ports, wind direction, wind speed, and their interactions. All regressions include weather controls, such as the quadratics of maximum, minimum, and dew point temperature, and precipitation. All regressions also include county-by-year, month, day-of-week, holiday, and zip code-port pair fixed effects. An observation is a zip code-port-day. Standard errors are clustered by zip code-port pair and day. Estimates are weighted by the zip code-specific population. Significance levels are indicated by ${ }^{* *} 1 \%$, $* * 5 \%$, and $* 10 \%$.

Table A.19: Effect of air pollution on hospitalizaton rates for Hispanics in California port areas

\begin{tabular}{|c|c|c|c|c|c|c|}
\hline & \multicolumn{6}{|c|}{ Dependent variable: hospital visits/million residents } \\
\hline & \multicolumn{3}{|c|}{ Respiratory } & \multirow{2}{*}{$\begin{array}{c}\text { Heart } \\
\text { All } \\
\text { Heart } \\
(4)\end{array}$} & \multicolumn{2}{|c|}{ Psychiatric } \\
\hline & $\begin{array}{c}\text { Asthma } \\
\text { (1) }\end{array}$ & $\begin{array}{c}\text { Upper } \\
\text { Respiratory } \\
\text { (2) }\end{array}$ & $\begin{array}{c}\text { All } \\
\text { Respiratory } \\
\text { (3) }\end{array}$ & & $\begin{array}{c}\text { Anxiety } \\
\text { (5) }\end{array}$ & $\begin{array}{c}\text { All } \\
\text { Psychiatric } \\
(6)\end{array}$ \\
\hline $\mathrm{CO}(\mathrm{ppb})$ & $\begin{array}{l}0.01^{* * *} \\
(0.002)\end{array}$ & $\begin{array}{l}0.02^{* * *} \\
(0.004)\end{array}$ & $\begin{array}{l}0.05^{* * *} \\
(0.01)\end{array}$ & $\begin{array}{l}0.01^{* * *} \\
(0.002)\end{array}$ & $\begin{array}{l}0.004^{* * *} \\
(0.001)\end{array}$ & $\begin{array}{l}0.01^{* * *} \\
(0.002)\end{array}$ \\
\hline $\mathrm{NO}_{2}(\mathrm{ppb})$ & $\begin{array}{l}0.30^{* * *} \\
(0.05)\end{array}$ & $\begin{array}{l}0.49^{* * *} \\
(0.10)\end{array}$ & $\begin{array}{l}1.30^{* * *} \\
(0.24)\end{array}$ & $\begin{array}{l}0.21^{* * *} \\
(0.05)\end{array}$ & $\begin{array}{l}0.10^{* * *} \\
(0.03)\end{array}$ & $\begin{array}{l}0.23^{* * *} \\
(0.06)\end{array}$ \\
\hline $\mathrm{PM}_{2.5}\left(\mu \mathrm{g} / \mathrm{m}^{3}\right)$ & $\begin{array}{l}0.35^{* * *} \\
(0.06)\end{array}$ & $\begin{array}{l}0.59^{* * * *} \\
(0.13)\end{array}$ & $\begin{array}{l}1.53^{* * *} \\
(0.31)\end{array}$ & $\begin{array}{l}0.20^{* * *} \\
(0.06)\end{array}$ & $\begin{array}{l}0.13^{* * *} \\
(0.03)\end{array}$ & $\begin{array}{l}0.26^{* * *} \\
(0.07)\end{array}$ \\
\hline $\mathrm{SO}_{2}(\mathrm{ppb})$ & $\begin{array}{l}9.76^{* * *} \\
(1.74)\end{array}$ & $\begin{array}{c}17.16^{* * *} \\
(3.46)\end{array}$ & $\begin{array}{c}43.82^{* * * *} \\
(7.95)\end{array}$ & $\begin{array}{l}5.88^{* * *} \\
(1.63)\end{array}$ & $\begin{array}{l}3.56^{* * *} \\
(0.96)\end{array}$ & $\begin{array}{l}7.75^{* * *} \\
(1.95)\end{array}$ \\
\hline
\end{tabular}

Notes: This table presents the instrumental variable estimation of the effect of air pollution on hospitalization rates for the Hispanic population. Each entry presents an individual regression of an air pollutant on an illness category. Pollution concentrations are instrumented by fitted vessel tonnage in ports, wind direction, wind speed, and their interactions. All regressions include weather controls, such as the quadratics of maximum temperature, minimum temperature, dew point temperature, and precipitation. All regressions also include county-by-year, month, day-of-week, holiday, and zip code-port pair fixed effects. An observation is a zip code-port-day. Standard errors are clustered by zip code-port pair and day. Estimates are weighted by the zip code-specific population. Significance levels are indicated by $* * * 1 \%,{ }^{* *} 5 \%$, and $* 10 \%$. 
Table A.20: Effect of air pollution on hospitalizaton rates in California port areas by age

\begin{tabular}{|c|c|c|c|c|c|c|}
\hline & \multicolumn{6}{|c|}{ Dependent variable: hospital visits/million residents in each age group } \\
\hline & \multicolumn{3}{|c|}{ Respiratory } & \multirow{2}{*}{$\begin{array}{c}\text { Heart } \\
\text { All } \\
\text { Heart } \\
(4)\end{array}$} & \multicolumn{2}{|c|}{ Psychiatric } \\
\hline & $\begin{array}{c}\text { Asthma } \\
\text { (1) }\end{array}$ & $\begin{array}{c}\text { Upper } \\
\text { Respiratory } \\
(2) \\
\end{array}$ & $\begin{array}{c}\text { All } \\
\text { Respiratory } \\
(3) \\
\end{array}$ & & $\begin{array}{c}\text { Anxiety } \\
\text { (5) }\end{array}$ & $\begin{array}{c}\text { All } \\
\text { Psychiatric } \\
(6)\end{array}$ \\
\hline \multicolumn{7}{|c|}{ Panel A: Ages 5 and under } \\
\hline $\mathrm{CO}(\mathrm{ppb})$ & $\begin{array}{l}0.01^{* *} \\
(0.01)\end{array}$ & $\begin{array}{l}0.06^{* * *} \\
(0.02)\end{array}$ & $\begin{array}{l}0.10^{* * *} \\
(0.04)\end{array}$ & $\begin{array}{l}0.002^{*} \\
(0.001)\end{array}$ & $\begin{array}{c}0.0005 \\
(0.0004)\end{array}$ & $\begin{array}{l}0.004^{* * *} \\
(0.001)\end{array}$ \\
\hline $\mathrm{NO}_{2}(\mathrm{ppb})$ & $\begin{array}{l}0.37^{* * *} \\
(0.14)\end{array}$ & $\begin{array}{l}1.67^{* * *} \\
(0.50)\end{array}$ & $\begin{array}{l}2.37^{* *} \\
(0.95)\end{array}$ & $\begin{array}{l}0.06^{*} \\
(0.03)\end{array}$ & $\begin{array}{c}0.01 \\
(0.01)\end{array}$ & $\begin{array}{l}0.09^{* * *} \\
(0.03)\end{array}$ \\
\hline $\mathrm{PM}_{2.5}\left(\mu \mathrm{g} / \mathrm{m}^{3}\right)$ & $\begin{array}{l}0.42^{* *} \\
(0.18)\end{array}$ & $\begin{array}{l}1.73^{* * *} \\
(0.64)\end{array}$ & $\begin{array}{l}2.31^{*} \\
(1.25)\end{array}$ & $\begin{array}{c}0.05 \\
(0.04)\end{array}$ & $\begin{array}{c}0.01 \\
(0.01)\end{array}$ & $\begin{array}{l}0.14^{* * *} \\
(0.03)\end{array}$ \\
\hline $\mathrm{SO}_{2}(\mathrm{ppb})$ & $\begin{array}{l}9.37^{* *} \\
(4.43)\end{array}$ & $\begin{array}{l}37.91^{* *} \\
(14.92)\end{array}$ & $\begin{array}{l}44.44 \\
(28.59)\end{array}$ & $\begin{array}{l}1.60^{*} \\
(0.93)\end{array}$ & $\begin{array}{c}0.33 \\
(0.29)\end{array}$ & $\begin{array}{l}2.41^{* * *} \\
(0.75)\end{array}$ \\
\hline \multicolumn{7}{|c|}{ Panel B: Ages between 5 and 19} \\
\hline $\mathrm{CO}(\mathrm{ppb})$ & $\begin{array}{l}0.01^{* * *} \\
(0.003)\end{array}$ & $\begin{array}{l}0.02^{* * *} \\
(0.01)\end{array}$ & $\begin{array}{l}0.04^{* * *} \\
(0.01)\end{array}$ & $\begin{array}{c}0.001 \\
(0.001)\end{array}$ & $\begin{array}{c}-0.0004 \\
(0.001)\end{array}$ & $\begin{array}{c}0.002 \\
(0.003)\end{array}$ \\
\hline $\mathrm{NO}_{2}(\mathrm{ppb})$ & $\begin{array}{l}0.29^{* * *} \\
(0.08)\end{array}$ & $\begin{array}{l}0.41^{* * *} \\
(0.12)\end{array}$ & $\begin{array}{l}0.79^{* * *} \\
(0.26)\end{array}$ & $\begin{array}{c}0.02 \\
(0.01)\end{array}$ & $\begin{array}{c}-0.003 \\
(0.02)\end{array}$ & $\begin{array}{c}0.10 \\
(0.06)\end{array}$ \\
\hline $\mathrm{PM}_{2.5}\left(\mu \mathrm{g} / \mathrm{m}^{3}\right)$ & $\begin{array}{l}0.36^{* * *} \\
(0.10)\end{array}$ & $\begin{array}{l}0.53^{* * *} \\
(0.16)\end{array}$ & $\begin{array}{l}1.02^{* * *} \\
(0.34)\end{array}$ & $\begin{array}{c}0.02 \\
(0.02)\end{array}$ & $\begin{array}{l}0.01 \\
(0.03)\end{array}$ & $\begin{array}{l}0.13^{*} \\
(0.08)\end{array}$ \\
\hline $\mathrm{SO}_{2}(\mathrm{ppb})$ & $\begin{array}{l}7.92^{* * *} \\
(2.44)\end{array}$ & $\begin{array}{c}13.48^{* * *} \\
(3.61)\end{array}$ & $\begin{array}{c}23.83^{* * *} \\
(7.63)\end{array}$ & $\begin{array}{c}0.39 \\
(0.38)\end{array}$ & $\begin{array}{l}-0.15 \\
(0.65)\end{array}$ & $\begin{array}{l}3.01^{*} \\
(1.81)\end{array}$ \\
\hline \multicolumn{7}{|c|}{ Panel C: Ages between 20 and 64} \\
\hline $\mathrm{CO}(\mathrm{ppb})$ & $\begin{array}{l}0.01^{* * *} \\
(0.002)\end{array}$ & $\begin{array}{l}0.01^{* * *} \\
(0.002)\end{array}$ & $\begin{array}{c}0.04^{* * *} \\
(0.01)\end{array}$ & $\begin{array}{l}0.01^{* * *} \\
(0.002)\end{array}$ & $\begin{array}{l}0.004^{* * *} \\
(0.002)\end{array}$ & $\begin{array}{c}0.01^{* *} \\
(0.003)\end{array}$ \\
\hline $\mathrm{NO}_{2}(\mathrm{ppb})$ & $\begin{array}{l}0.23^{* * *} \\
(0.04)\end{array}$ & $\begin{array}{l}0.26^{* * *} \\
(0.04)\end{array}$ & $\begin{array}{l}0.87^{* * *} \\
(0.13)\end{array}$ & $\begin{array}{l}0.15^{* * *} \\
(0.05)\end{array}$ & $\begin{array}{l}0.11^{* * *} \\
(0.04)\end{array}$ & $\begin{array}{l}0.18^{* *} \\
(0.08)\end{array}$ \\
\hline $\mathrm{PM}_{2.5}\left(\mu \mathrm{g} / \mathrm{m}^{3}\right)$ & $\begin{array}{l}0.29^{* * *} \\
(0.06)\end{array}$ & $\begin{array}{l}0.34^{* * *} \\
(0.05)\end{array}$ & $\begin{array}{l}1.10^{* * *} \\
(0.18)\end{array}$ & $\begin{array}{l}0.16^{* * *} \\
(0.06)\end{array}$ & $\begin{array}{l}0.13^{* * *} \\
(0.05)\end{array}$ & $\begin{array}{l}0.19^{*} \\
(0.11)\end{array}$ \\
\hline $\mathrm{SO}_{2}(\mathrm{ppb})$ & $\begin{array}{l}6.15^{* * *} \\
(1.29)\end{array}$ & $\begin{array}{l}8.22^{* * *} \\
(1.23)\end{array}$ & $\begin{array}{l}25.36^{* * * *} \\
(4.04)\end{array}$ & $\begin{array}{l}4.13^{* * *} \\
(1.30)\end{array}$ & $\begin{array}{l}3.25^{* * *} \\
(1.05)\end{array}$ & $\begin{array}{l}5.42^{* *} \\
(2.31)\end{array}$ \\
\hline \multicolumn{7}{|c|}{ Panel D: Ages 65 and above } \\
\hline $\mathrm{CO}(\mathrm{ppb})$ & $\begin{array}{l}0.02^{* * *} \\
(0.01)\end{array}$ & $\begin{array}{c}0.002 \\
(0.002)\end{array}$ & $\begin{array}{l}0.07^{* * *} \\
(0.02)\end{array}$ & $\begin{array}{l}0.08^{* * *} \\
(0.02)\end{array}$ & $\begin{array}{c}0.003 \\
(0.004)\end{array}$ & $\begin{array}{l}0.03^{* * *} \\
(0.01)\end{array}$ \\
\hline $\mathrm{NO}_{2}(\mathrm{ppb})$ & $\begin{array}{l}0.48^{* * *} \\
(0.12)\end{array}$ & $\begin{array}{l}0.11^{* *} \\
(0.05)\end{array}$ & $\begin{array}{l}1.71^{* * *} \\
(0.42)\end{array}$ & $\begin{array}{l}2.02^{* * *} \\
(0.42)\end{array}$ & $\begin{array}{c}0.11 \\
(0.10)\end{array}$ & $\begin{array}{l}0.71^{* * *} \\
(0.22)\end{array}$ \\
\hline $\mathrm{PM}_{2.5}\left(\mu \mathrm{g} / \mathrm{m}^{3}\right)$ & $\begin{array}{l}0.58^{* * *} \\
(0.16)\end{array}$ & $\begin{array}{c}0.11 \\
(0.07)\end{array}$ & $\begin{array}{l}2.13^{* * *} \\
(0.59)\end{array}$ & $\begin{array}{l}2.46^{* * *} \\
(0.58)\end{array}$ & $\begin{array}{c}0.10 \\
(0.14)\end{array}$ & $\begin{array}{l}0.81^{* * *} \\
(0.30)\end{array}$ \\
\hline $\mathrm{SO}_{2}(\mathrm{ppb})$ & $\begin{array}{c}13.16^{* * *} \\
(3.32)\end{array}$ & $\begin{array}{l}3.37^{* *} \\
(1.50)\end{array}$ & $\begin{array}{l}44.62^{* * *} \\
(11.51)\end{array}$ & $\begin{array}{l}50.78^{* * *} \\
(11.72)\end{array}$ & $\begin{array}{l}4.78^{*} \\
(2.71)\end{array}$ & $\begin{array}{c}22.07^{* * *} \\
(6.15)\end{array}$ \\
\hline
\end{tabular}

Notes: This table presents the instrumental variable estimation of the effect of air pollution on hospitalization rates by age. Each entry presents an individual regression of an air pollutant on an illness category. Pollution concentrations are instrumented by fitted vessel tonnage in ports, wind direction, wind speed, and their interactions. All regressions include weather controls, such as the quadratics of maximum temperature, minimum temperature, dew point temperature, and precipitation. All regressions also include county-by-year, month, day-of-week, holiday, and zip code-port pair fixed effects. An observation is a zip code-port-day. Standard errors are clustered by zip code-port pair and day. Estimates are weighted by the zip code-specific population. Significance levels are indicated by $* * * 1 \%, * * 5 \%$, and $* 10 \%$. 


\section{Table A.21: Effect of air pollution on hospitalizaton rates in California port areas by sex}

\begin{tabular}{|c|c|c|c|c|c|c|}
\hline & \multicolumn{6}{|c|}{ Dependent variable: hospital visits/million residents in each sex group } \\
\hline & \multicolumn{3}{|c|}{ Respiratory } & \multirow{2}{*}{$\begin{array}{c}\frac{\text { Heart }}{\text { All }} \\
\text { Heart } \\
(4)\end{array}$} & \multicolumn{2}{|c|}{ Psychiatric } \\
\hline & $\begin{array}{c}\text { Asthma } \\
\text { (1) }\end{array}$ & $\begin{array}{c}\text { Upper } \\
\text { Respiratory } \\
(2) \\
\end{array}$ & $\begin{array}{c}\text { All } \\
\text { Respiratory } \\
(3) \\
\end{array}$ & & $\begin{array}{c}\text { Anxiety } \\
(5)\end{array}$ & $\begin{array}{c}\text { All } \\
\text { Psychiatric } \\
(6)\end{array}$ \\
\hline \multicolumn{7}{|l|}{ Panel A: Male } \\
\hline $\mathrm{CO}(\mathrm{ppb})$ & $\begin{array}{l}0.01^{* * *} \\
(0.002)\end{array}$ & $\begin{array}{l}0.01^{* * *} \\
(0.003)\end{array}$ & $\begin{array}{l}0.04^{* * *} \\
(0.01)\end{array}$ & $\begin{array}{l}0.01^{* * *} \\
(0.004)\end{array}$ & $\begin{array}{l}0.003^{* * * *} \\
(0.001)\end{array}$ & $\begin{array}{l}0.01^{* * *} \\
(0.003)\end{array}$ \\
\hline $\mathrm{NO}_{2}(\mathrm{ppb})$ & $\begin{array}{l}0.22^{* * *} \\
(0.04)\end{array}$ & $\begin{array}{l}0.28^{* * * *} \\
(0.07)\end{array}$ & $\begin{array}{l}0.89^{* * * *} \\
(0.18)\end{array}$ & $\begin{array}{l}0.33^{* * *} \\
(0.08)\end{array}$ & $\begin{array}{l}0.07^{* * *} \\
(0.03)\end{array}$ & $\begin{array}{l}0.22^{* * *} \\
(0.07)\end{array}$ \\
\hline $\mathrm{PM}_{2.5}\left(\mu \mathrm{g} / \mathrm{m}^{3}\right)$ & $\begin{array}{l}0.27^{* * *} \\
(0.06)\end{array}$ & $\begin{array}{l}0.34^{* * *} \\
(0.09)\end{array}$ & $\begin{array}{l}1.10^{* * *} \\
(0.25)\end{array}$ & $\begin{array}{l}0.35^{* * *} \\
(0.11)\end{array}$ & $\begin{array}{l}0.08^{* *} \\
(0.03)\end{array}$ & $\begin{array}{l}0.23^{* * *} \\
(0.09)\end{array}$ \\
\hline $\mathrm{SO}_{2}(\mathrm{ppb})$ & $\begin{array}{l}5.24^{* * *} \\
(1.32)\end{array}$ & $\begin{array}{l}7.17^{* * *} \\
(2.02)\end{array}$ & $\begin{array}{l}22.98^{* * * *} \\
(5.24)\end{array}$ & $\begin{array}{l}8.52^{* * *} \\
(2.40)\end{array}$ & $\begin{array}{l}2.16^{* * *} \\
(0.73)\end{array}$ & $\begin{array}{l}6.22^{* * *} \\
(1.92)\end{array}$ \\
\hline \multicolumn{7}{|l|}{ Panel B: Female } \\
\hline $\mathrm{CO}(\mathrm{ppb})$ & $\begin{array}{l}0.02^{* * *} \\
(0.002)\end{array}$ & $\begin{array}{l}0.02^{* * *} \\
(0.003)\end{array}$ & $\begin{array}{l}0.05^{* * *} \\
(0.01)\end{array}$ & $\begin{array}{l}0.02^{* * *} \\
(0.003)\end{array}$ & $\begin{array}{l}0.004^{* *} \\
(0.002)\end{array}$ & $\begin{array}{l}0.01^{* *} \\
(0.004)\end{array}$ \\
\hline $\mathrm{NO}_{2}(\mathrm{ppb})$ & $\begin{array}{l}0.34^{* * *} \\
(0.06)\end{array}$ & $\begin{array}{l}0.41^{* * *} \\
(0.08)\end{array}$ & $\begin{array}{l}1.18^{* * *} \\
(0.21)\end{array}$ & $\begin{array}{l}0.40^{* * *} \\
(0.07)\end{array}$ & $\begin{array}{l}0.10^{* *} \\
(0.04)\end{array}$ & $\begin{array}{l}0.25^{* * *} \\
(0.09)\end{array}$ \\
\hline $\mathrm{PM}_{2.5}\left(\mu \mathrm{g} / \mathrm{m}^{3}\right)$ & $\begin{array}{l}0.43^{* * *} \\
(0.08)\end{array}$ & $\begin{array}{l}0.49^{* * *} \\
(0.11)\end{array}$ & $\begin{array}{l}1.46^{* * *} \\
(0.29)\end{array}$ & $\begin{array}{l}0.50^{* * *} \\
(0.09)\end{array}$ & $\begin{array}{l}0.12^{* *} \\
(0.06)\end{array}$ & $\begin{array}{l}0.29^{* *} \\
(0.12)\end{array}$ \\
\hline $\mathrm{SO}_{2}(\mathrm{ppb})$ & $\begin{array}{l}9.44^{* * *} \\
(1.71)\end{array}$ & $\begin{array}{l}11.28^{* * * *} \\
(2.37)\end{array}$ & $\begin{array}{l}31.83^{* * * *} \\
(6.25)\end{array}$ & $\begin{array}{l}11.42^{* * * *} \\
(2.03)\end{array}$ & $\begin{array}{l}3.24^{* * *} \\
(1.23)\end{array}$ & $\begin{array}{l}7.72^{* * *} \\
(2.67)\end{array}$ \\
\hline
\end{tabular}

Notes: This table presents the instrumental variable estimation of the effect of air pollution on hospitalization rates by sex. Each entry presents an individual regression of an air pollutant on an illness category. Pollution concentrations are instrumented by fitted vessel tonnage in ports, wind direction, wind speed, and their interactions. All regressions include weather controls, such as the quadratics of maximum temperature, minimum temperature, dew point temperature, and precipitation. All regressions also include county-by-year, month, day-of-week, holiday, and zip code-port pair fixed effects. An observation is a zip code-port-day. Standard errors are clustered by zip code-port pair and day. Estimates are weighted by the zip code-specific population. Significance levels are indicated by ${ }^{* * *} 1 \%$, ** $5 \%$, and ${ }^{*} 10 \%$. 
Table A.22: Effect of one standard deviation increase of air pollution on annual hospitalizations and medical costs in California port areas

\begin{tabular}{lccc}
\hline \hline & $\begin{array}{c}\text { All } \\
\text { Respiratory } \\
(1)\end{array}$ & $\begin{array}{c}\text { All } \\
\text { Heart } \\
(2)\end{array}$ & $\begin{array}{c}\text { All } \\
\text { Psychiatric } \\
(3)\end{array}$ \\
\hline Panel A: Hospital visits per million residents & & \\
Black & 46,000 & 9,700 & 2,500 \\
White & 9,900 & 5,400 & 4,400 \\
Overall Population & 15,000 & 5,400 & 3,800 \\
\hline Panel B: Medical costs per capita (2017 USD) & & 22 \\
Black & 401 & 94 & 39 \\
White & 86 & 52 & 34 \\
Overall Population & 131 & 52 & \\
\hline \hline
\end{tabular}

Notes: Panel A presents the back-of-the-envelope calculations of the effect of one standard deviation increase of air pollution on daily hospital visits in the port areas of California, based on the instrumental variable estimates in Panel A of Table 2. Panel B presents the medical costs associated with the hospital visits in Panel A based on the payment data from the Centers for Medicare and Medicaid Services. The average medical costs are $\$ 8,917$ for psychiatric illnesses, \$8,715 for respiratory illnesses, and \$9,679 for heart-related illnesses. Based on the U.S. 2010 Decennial Census, the total population residing in the zip codes within 25 miles of California's major ports is 15.08 million, of which 1.12 million are Black 5.07 million are white. All numbers are rounded to two significant figures. 
Table A.23: Effect of air pollution on hospitalizaton rates of placebo illnesses for the overall population in California port areas, instrumental variable estimation

\begin{tabular}{|c|c|c|c|}
\hline & \multicolumn{3}{|c|}{ Dependent variable: hospital visits/million residents } \\
\hline & $\begin{array}{c}\text { Arterial } \\
\text { Embolism } \\
(1)\end{array}$ & $\begin{array}{c}\text { Neck } \\
\text { Wound } \\
(2)\end{array}$ & $\begin{array}{c}\text { Appendicitis } \\
\text { (3) }\end{array}$ \\
\hline \multicolumn{4}{|l|}{ Panel A: CO } \\
\hline $\mathrm{CO}(\mathrm{ppb})$ & $\begin{array}{c}0.0000 \\
(0.0000)\end{array}$ & $\begin{array}{l}-0.0000 \\
(0.0000)\end{array}$ & $\begin{array}{c}0.0003 \\
(0.0002)\end{array}$ \\
\hline $\begin{array}{l}\text { Adjusted } R^{2} \\
\text { Observations }\end{array}$ & $\begin{array}{c}0.00 \\
2,215,370\end{array}$ & $\begin{array}{c}0.00 \\
2,215,370\end{array}$ & $\begin{array}{c}0.01 \\
2,215,370\end{array}$ \\
\hline \multicolumn{4}{|l|}{ Panel B: $\mathrm{NO}_{2}$} \\
\hline $\mathrm{NO}_{2}(\mathrm{ppb})$ & $\begin{array}{l}0.0003 \\
(0.001) \\
\end{array}$ & $\begin{array}{c}-0.0002 \\
(0.001) \\
\end{array}$ & $\begin{array}{c}0.01 \\
(0.01)\end{array}$ \\
\hline $\begin{array}{l}\text { Adjusted } R^{2} \\
\text { Observations }\end{array}$ & $\begin{array}{c}0.00 \\
2,288,952\end{array}$ & $\begin{array}{c}0.00 \\
2,288,952\end{array}$ & $\begin{array}{c}0.01 \\
2,288,952\end{array}$ \\
\hline \multicolumn{4}{|l|}{ Panel C: $\mathbf{P M}_{2.5}$} \\
\hline $\mathrm{PM}_{2.5}\left(\mu \mathrm{g} / \mathrm{m}^{3}\right)$ & $\begin{array}{c}0.001 \\
(0.001)\end{array}$ & $\begin{array}{c}-0.0002 \\
(0.001)\end{array}$ & $\begin{array}{c}0.01 \\
(0.01)\end{array}$ \\
\hline $\begin{array}{l}\text { Adjusted } R^{2} \\
\text { Observations }\end{array}$ & $\begin{array}{c}0.00 \\
2,184,088\end{array}$ & $\begin{array}{c}0.00 \\
2,184,088\end{array}$ & $\begin{array}{c}0.01 \\
2,184,088\end{array}$ \\
\hline \multicolumn{4}{|l|}{ Panel D: $\mathrm{SO}_{2}$} \\
\hline $\mathrm{SO}_{2}(\mathrm{ppb})$ & $\begin{array}{c}0.01 \\
(0.04)\end{array}$ & $\begin{array}{l}-0.02 \\
(0.03)\end{array}$ & $\begin{array}{c}0.20 \\
(0.19)\end{array}$ \\
\hline $\begin{array}{l}\text { Adjusted } R^{2} \\
\text { Observations }\end{array}$ & $\begin{array}{c}0.00 \\
1,938,097\end{array}$ & $\begin{array}{c}0.00 \\
1,938,097\end{array}$ & $\begin{array}{c}0.01 \\
1,938,097\end{array}$ \\
\hline
\end{tabular}

Notes: This table presents the instrumental variable estimation of the effect of air pollution on hospitalization rates for placebo illnesses. Each entry presents an individual regression of an air pollutant on an illness category. Pollution concentrations are instrumented by fitted vessel tonnage in ports, wind direction, wind speed, and their interactions. All regressions include weather controls, such as the quadratics of maximum temperature, minimum temperature, dew point temperature, and precipitation. All regressions also include county-by-year, month, day-of-week, holiday, and zip code-port pair fixed effects. An observation is a zip code-port-day. Standard errors are clustered by zip code-port pair and day. Estimates are weighted by the zip code-specific population. Significance levels are indicated by ${ }^{* * *} 1 \%,{ }^{* *} 5 \%$, and ${ }^{*} 10 \%$. 
Table A.24: Robustness check for the effect of vessel tonnage in port on air pollution, various model specifications

\begin{tabular}{|c|c|c|c|c|}
\hline & \multicolumn{4}{|c|}{ Dependent variable: $\log$ of pollution concentration } \\
\hline & $\mathrm{CO}$ & $\mathrm{NO}_{2}$ & $\mathrm{PM}_{2.5}$ & $\mathrm{SO}_{2}$ \\
\hline & $(1)$ & $(2)$ & (3) & $(4)$ \\
\hline \multicolumn{5}{|c|}{ Panel A: No weather controls and temporal fixed effects } \\
\hline Log of Vessel Tonnage & $\begin{array}{l}10.34 \\
(8.35) \\
\end{array}$ & $\begin{array}{l}10.66 \\
(6.94) \\
\end{array}$ & $\begin{array}{c}1.16 \\
(0.76) \\
\end{array}$ & $\begin{array}{c}19.66 \\
(22.17) \\
\end{array}$ \\
\hline Adjusted $R^{2}$ & -62.20 & -64.60 & -1.44 & -87.77 \\
\hline Observations & 502,631 & 587,833 & 423,200 & 431,574 \\
\hline \multicolumn{5}{|c|}{ Panel B: No weather controls } \\
\hline Log of Vessel Tonnage & $\begin{array}{l}0.35^{* *} \\
(0.17) \\
\end{array}$ & $\begin{array}{c}0.12 \\
(0.18) \\
\end{array}$ & $\begin{array}{c}0.45^{*} \\
(0.23) \\
\end{array}$ & $\begin{array}{c}0.34 \\
(0.23) \\
\end{array}$ \\
\hline Adjusted $\mathrm{R}^{2}$ & 0.42 & 0.62 & 0.02 & 0.43 \\
\hline Observations & 502,631 & 587,833 & 423,200 & 431,574 \\
\hline \multicolumn{5}{|c|}{ Panel C: No temporal fixed effects } \\
\hline Log of Vessel Tonnage & $\begin{array}{c}4.65 \\
(2.83) \\
\end{array}$ & $\begin{array}{c}0.96 \\
(0.88) \\
\end{array}$ & $\begin{array}{c}3.67^{* * *} \\
(1.08) \\
\end{array}$ & $\begin{array}{c}2.33 \\
(2.09) \\
\end{array}$ \\
\hline Adjusted $\mathrm{R}^{2}$ & -12.30 & 0.11 & -15.14 & -0.99 \\
\hline Observations & 502,631 & 587,833 & 423,200 & 431,574 \\
\hline \multicolumn{5}{|c|}{ Panel D: No quadratic weather terms } \\
\hline Log of Vessel Tonnage & $\begin{array}{l}0.33^{* *} \\
(0.13) \\
\end{array}$ & $\begin{array}{c}0.23^{*} \\
(0.12) \\
\end{array}$ & $\begin{array}{c}0.34^{*} \\
(0.18) \\
\end{array}$ & $\begin{array}{c}0.29 \\
(0.19) \\
\end{array}$ \\
\hline Adjusted $\mathrm{R}^{2}$ & 0.51 & 0.72 & 0.28 & 0.48 \\
\hline Observations & 502,631 & 587,833 & 423,200 & 431,574 \\
\hline \multicolumn{5}{|c|}{ Panel E: Monitors within 12.5 miles of ports } \\
\hline Log of Vessel Tonnage & $\begin{array}{c}0.23 \\
(0.15) \\
\end{array}$ & $\begin{array}{c}0.16 \\
(0.13) \\
\end{array}$ & $\begin{array}{l}0.45^{* *} \\
(0.18) \\
\end{array}$ & $\begin{array}{l}0.50^{* *} \\
(0.25) \\
\end{array}$ \\
\hline Adjusted $\mathrm{R}^{2}$ & 0.54 & 0.73 & 0.23 & 0.43 \\
\hline Observations & 258,799 & 278,898 & 229,503 & 256,711 \\
\hline
\end{tabular}

Notes: This table presents the robustness check results for Table 1 with various model specifications. Each panel presents regressions using an alternative model specification. Log vessel tonnage is instrumented by an indicator of seven-day lagged and 500-mile distant cyclones from ports. All regressions include weather controls, such as the quadratics of maximum temperature, minimum temperature, dew point temperature, precipitation, wind speed, and relative wind direction between a monitor-port pair. All regressions also include county-by-year, month, day-of-week, holiday, and monitor-port pair fixed effects. Standard errors are clustered by monitor-port pair and day. Significance levels are indicated by $* * * 1 \%, * * \%$, and $* 10 \%$. 
Table A.25: Robustness check for the effect of vessel tonnage in port on air pollution, various instrumental variable specifications

\begin{tabular}{lcccc}
\hline \hline & \multicolumn{3}{c}{ Dependent variable: log of pollution concentration } \\
\cline { 2 - 5 } & $\mathrm{CO}$ & $\mathrm{NO}_{2}$ & $\mathrm{PM}_{2.5}$ & $\mathrm{SO}_{2}$ \\
& $(1)$ & $(2)$ & $(3)$ & $(4)$ \\
\hline Panel A: Exclude cyclones within & $\mathbf{8 0 0}$ miles of ports & & & \\
Log of Vessel Tonnage & $0.44^{* * *}$ & $0.28^{* *}$ & $0.40^{* *}$ & $0.56^{* *}$ \\
& $(0.13)$ & $(0.13)$ & $(0.18)$ & $(0.24)$ \\
\cline { 2 - 5 } Adjusted $\mathrm{R}^{2}$ & 0.48 & 0.71 & 0.30 & 0.44 \\
Observations & 502,631 & 587,833 & 423,200 & 431,574 \\
\hline
\end{tabular}

Panel B: Six-day lagged cyclones

Log of Vessel Tonnage

\begin{tabular}{cccc}
$0.33^{* * *}$ & $0.31^{* *}$ & $0.40^{* *}$ & $0.45^{* *}$ \\
$(0.12)$ & $(0.12)$ & $(0.18)$ & $(0.19)$ \\
\hline 0.51 & 0.70 & 0.29 & 0.46 \\
502,631 & 587,833 & 423,200 & 431,574
\end{tabular}

Adjusted $R^{2}$

Observations

\begin{tabular}{cccc}
$0.40^{* *}$ & 0.18 & $0.49^{* *}$ & 0.36 \\
$(0.16)$ & $(0.14)$ & $(0.23)$ & $(0.27)$ \\
\hline 0.49 & 0.74 & 0.21 & 0.48 \\
502,631 & 587,833 & 423,200 & 431,574 \\
\hline
\end{tabular}

Panel C: Eight-day lagged cyclones

Log of Vessel Tonnage

Adjusted $R^{2}$

Observations

502,631

31,574

Panel D: Six-, seven-, and eight-day lagged cyclones (2SLS)

Log of Vessel Tonnage

\begin{tabular}{cccc}
$0.35^{* * *}$ & $0.27^{* *}$ & $0.42^{* *}$ & $0.44^{* *}$ \\
$(0.12)$ & $(0.12)$ & $(0.17)$ & $(0.18)$ \\
\hline 0.51 & 0.72 & 0.28 & 0.47 \\
502,631 & 587,833 & 423,200 & 431,574
\end{tabular}

Adjusted $R^{2}$

Observations

502,631

Panel E: Six-, seven-, and eight-day lagged cyclones (LIML)

Log of Vessel Tonnage

\begin{tabular}{cccc}
$0.35^{* * *}$ & $0.28^{* *}$ & $0.42^{* *}$ & $0.45^{* *}$ \\
$(0.12)$ & $(0.12)$ & $(0.17)$ & $(0.18)$ \\
\hline 0.51 & 0.71 & 0.28 & 0.46 \\
502,631 & 587,833 & 423,200 & 431,574 \\
\hline
\end{tabular}

Panel F: Cyclone counts

Log of Vessel Tonnage

Adjusted $R^{2}$

Observations

\begin{tabular}{cccc}
$0.34^{* *}$ & $0.29^{* *}$ & $0.39^{* *}$ & $0.35^{*}$ \\
$(0.14)$ & $(0.13)$ & $(0.17)$ & $(0.20)$ \\
\hline 0.51 & 0.71 & 0.30 & 0.48 \\
502,631 & 587,833 & 423,200 & 431,574 \\
\hline
\end{tabular}

Notes: This table presents the results of robustness check for Table 1 with various instrumental variable specifications. Each panel presents regressions using an alternative instrumental variable specification. All regressions include weather controls, such as the quadratics of maximum temperature, minimum temperature, dew point temperature, precipitation, wind speed, and relative wind direction between a monitor-port pair. All regressions also include county-by-year, month, day-of-week, holiday, and monitor-port pair fixed effects. Standard errors are clustered by monitor-port pair and day. Significance levels are indicated by $* * * 1 \%, * * 5 \%$, and ${ }^{*} 10 \%$. 
Table A.26: Robustness check for the effect of vessel tonnage in port on air pollution, including the observations where cyclones are close to ports

\begin{tabular}{|c|c|c|c|c|}
\hline & \multicolumn{4}{|c|}{ Dependent variable: $\log$ of pollution concentration } \\
\hline & $\mathrm{CO}$ & $\mathrm{NO}_{2}$ & $\mathrm{PM}_{2.5}$ & $\mathrm{SO}_{2}$ \\
\hline & $(1)$ & $(2)$ & (3) & $(4)$ \\
\hline Log of Vessel Tonnage & $\begin{array}{l}0.34^{* *} \\
(0.13)\end{array}$ & $\begin{array}{c}0.23^{*} \\
(0.12)\end{array}$ & $\begin{array}{l}0.40^{* *} \\
(0.17)\end{array}$ & $\begin{array}{c}0.38^{*} \\
(0.20)\end{array}$ \\
\hline First-Stage F Stat. & 30.88 & 36.64 & 34.19 & 28.69 \\
\hline Adjusted $R^{2}$ & 0.51 & 0.72 & 0.29 & 0.47 \\
\hline Observations & 513,256 & 600,681 & 433,377 & 442,141 \\
\hline
\end{tabular}

Notes: This table presents the instrumental variable estimation of the effect of vessel tonnage in ports on air pollution, where we include the dates when there exist tropical cyclones near ports (e.g., within the 300-mile radius of ports) and two days before and after the events. Each column presents an individual regression on a local air pollutant. Log of vessel tonnage is instrumented by an indicator of seven-day lagged and 500-mile distant cyclones from ports. All regressions include weather controls, such as the quadratics of maximum temperature, minimum temperature, dew point temperature, precipitation, wind speed, and relative wind direction between a monitor-port pair. All regressions also include county-by-year, month, day-of-week, holiday, and monitor-port pair fixed effects. Standard errors are clustered by monitor-port pair and day. Significance levels are indicated by ${ }^{* * *} 1 \%, * * 5 \%$, and $* 10 \%$. 
Table A.27: Effect of air pollution on hospitalization rates in California port areas - joint estimation with zip codes within a 25-mile radius from ports

\begin{tabular}{|c|c|c|c|c|c|c|c|c|c|}
\hline & \multicolumn{9}{|c|}{ Dependent variable: hospital visits/million residents } \\
\hline & \multicolumn{3}{|c|}{ All Respiratory } & \multicolumn{3}{|c|}{ All Heart } & \multicolumn{3}{|c|}{ All Psychiatric } \\
\hline & $(1)$ & $(2)$ & $(3)$ & $(4)$ & $(5)$ & $(6)$ & $(7)$ & $(8)$ & $(9)$ \\
\hline \multicolumn{10}{|l|}{ Panel A: Overall population } \\
\hline $\mathrm{CO}(\mathrm{ppb})$ & $\begin{array}{l}0.07^{* * *} \\
(0.02)\end{array}$ & $\begin{array}{l}0.05^{* * *} \\
(0.01)\end{array}$ & $\begin{array}{l}0.10^{* * *} \\
(0.03)\end{array}$ & $\begin{array}{l}0.003 \\
(0.01)\end{array}$ & $\begin{array}{c}0.01 \\
(0.005)\end{array}$ & $\begin{array}{c}0.01 \\
(0.01)\end{array}$ & $\begin{array}{c}-0.003 \\
(0.01)\end{array}$ & $\begin{array}{l}0.0004 \\
(0.005)\end{array}$ & $\begin{array}{l}0.002 \\
(0.01)\end{array}$ \\
\hline $\mathrm{NO}_{2}(\mathrm{ppb})$ & $\begin{array}{l}-0.63 \\
(0.58)\end{array}$ & & $\begin{array}{c}-2.66^{* * *} \\
(1.00)\end{array}$ & $\begin{array}{l}0.30^{*} \\
(0.18)\end{array}$ & & $\begin{array}{c}0.08 \\
(0.35)\end{array}$ & $\begin{array}{c}0.30 \\
(0.20)\end{array}$ & & $\begin{array}{l}-0.10 \\
(0.40)\end{array}$ \\
\hline $\mathrm{SO}_{2}(\mathrm{ppb})$ & & $\begin{array}{c}1.64 \\
(9.84)\end{array}$ & $\begin{array}{l}38.20^{* *} \\
(16.56)\end{array}$ & & $\begin{array}{l}5.96^{* *} \\
(2.95)\end{array}$ & $\begin{array}{c}4.89 \\
(5.68)\end{array}$ & & $\begin{array}{l}6.73^{* *} \\
(3.19)\end{array}$ & $\begin{array}{c}8.07 \\
(6.22)\end{array}$ \\
\hline First-stage F Stat. & 23.02 & 10.89 & 5.61 & 23.02 & 10.89 & 5.61 & 23.02 & 10.89 & 5.61 \\
\hline Anderson-Rubin Stat. P-val & $3.33 e-10$ & $4.39 \mathrm{e}-10$ & $4.36 \mathrm{e}-10$ & $3.33 e-10$ & $4.39 \mathrm{e}-10$ & $4.36 \mathrm{e}-10$ & $3.33 e-10$ & $4.39 \mathrm{e}-10$ & $4.36 \mathrm{e}-10$ \\
\hline Stock-Wright S Stat. P-val & $4.62 \mathrm{e}-06$ & $5.79 \mathrm{e}-06$ & $5.75 \mathrm{e}-06$ & $4.62 \mathrm{e}-06$ & $5.79 \mathrm{e}-06$ & $5.75 \mathrm{e}-06$ & $4.62 \mathrm{e}-06$ & $5.79 \mathrm{e}-06$ & $5.75 \mathrm{e}-06$ \\
\hline Observations & $1,782,259$ & $1,748,298$ & $1,748,291$ & $1,782,259$ & $1,748,298$ & $1,748,291$ & $1,782,259$ & $1,748,298$ & $1,748,291$ \\
\hline \multicolumn{10}{|l|}{ Panel B: Black } \\
\hline $\mathrm{CO}(\mathrm{ppb})$ & $\begin{array}{l}-0.03 \\
(0.06)\end{array}$ & $\begin{array}{l}-0.02 \\
(0.03)\end{array}$ & $\begin{array}{c}0.10 \\
(0.07)\end{array}$ & $\begin{array}{c}0.01 \\
(0.02)\end{array}$ & $\begin{array}{c}0.02 \\
(0.01)\end{array}$ & $\begin{array}{c}0.02 \\
(0.03)\end{array}$ & $\begin{array}{l}-0.02 \\
(0.03)\end{array}$ & $\begin{array}{l}-0.02 \\
(0.01)\end{array}$ & $\begin{array}{l}-0.01 \\
(0.03)\end{array}$ \\
\hline $\mathrm{NO}_{2}(\mathrm{ppb})$ & $\begin{array}{l}3.59^{* *} \\
(1.63)\end{array}$ & & $\begin{array}{r}-5.52^{*} \\
(2.95)\end{array}$ & $\begin{array}{c}0.42 \\
(0.61)\end{array}$ & & $\begin{array}{l}-0.27 \\
(1.00)\end{array}$ & $\begin{array}{c}0.62 \\
(0.70)\end{array}$ & & $\begin{array}{l}-0.51 \\
(1.33)\end{array}$ \\
\hline $\mathrm{SO}_{2}(\mathrm{ppb})$ & & $\begin{array}{c}94.67^{* * *} \\
(24.72)\end{array}$ & $\begin{array}{c}166.60^{* * *} \\
(43.42)\end{array}$ & & $\begin{array}{c}9.19 \\
(9.57) \\
\end{array}$ & $\begin{array}{c}12.72 \\
(15.59) \\
\end{array}$ & & $\begin{array}{c}14.71 \\
(10.22) \\
\end{array}$ & $\begin{array}{c}21.32 \\
(19.25) \\
\end{array}$ \\
\hline First-stage F Stat. & 15.70 & 11.38 & 5.43 & 15.70 & 11.38 & 5.43 & 15.70 & 11.38 & 5.43 \\
\hline Anderson-Rubin Stat. P-val & 0 & 0 & 0 & 0 & 0 & 0 & 0 & 0 & 0 \\
\hline Stock-Wright S Stat. P-val & 0.000399 & 0.000321 & 0.000321 & 0.000399 & 0.000321 & 0.000321 & 0.000399 & 0.000321 & 0.000321 \\
\hline Observations & 877,506 & 871,732 & 871,730 & 877,506 & 871,732 & 871,730 & 877,506 & 871,732 & 871,730 \\
\hline \multicolumn{10}{|l|}{ Panel C: White } \\
\hline $\mathrm{CO}(\mathrm{ppb})$ & $\begin{array}{l}0.08^{* * *} \\
(0.02)\end{array}$ & $\begin{array}{l}0.06^{* * *} \\
(0.01)\end{array}$ & $\begin{array}{l}0.09^{* * *} \\
(0.02)\end{array}$ & $\begin{array}{c}0.02 \\
(0.01)\end{array}$ & $\begin{array}{l}0.02^{*} \\
(0.01)\end{array}$ & $\begin{array}{c}0.01 \\
(0.02)\end{array}$ & $\begin{array}{l}0.002 \\
(0.01)\end{array}$ & $\begin{array}{l}0.002 \\
(0.01)\end{array}$ & $\begin{array}{c}0.01 \\
(0.02)\end{array}$ \\
\hline $\mathrm{NO}_{2}(\mathrm{ppb})$ & $\begin{array}{r}-0.92^{*} \\
(0.48)\end{array}$ & & $\begin{array}{r}-1.62^{*} \\
(0.88)\end{array}$ & $\begin{array}{c}0.09 \\
(0.30)\end{array}$ & & $\begin{array}{c}0.21 \\
(0.65)\end{array}$ & $\begin{array}{c}0.26 \\
(0.33)\end{array}$ & & $\begin{array}{l}-0.25 \\
(0.72)\end{array}$ \\
\hline $\mathrm{SO}_{2}(\mathrm{ppb})$ & & $\begin{array}{c}-10.28 \\
(7.32) \\
\end{array}$ & $\begin{array}{c}9.90 \\
(13.12) \\
\end{array}$ & & $\begin{array}{c}2.59 \\
(4.64) \\
\end{array}$ & $\begin{array}{l}-0.07 \\
(9.66)\end{array}$ & & $\begin{array}{c}6.92 \\
(4.90) \\
\end{array}$ & $\begin{array}{c}10.04 \\
(10.31) \\
\end{array}$ \\
\hline First-stage F Stat. & 26.28 & 11.11 & 4.42 & 26.28 & 11.11 & 4.42 & 26.28 & 11.11 & 4.42 \\
\hline Anderson-Rubin Stat. P-val & $6.18 \mathrm{e}-10$ & $7.22 \mathrm{e}-10$ & $7.11 \mathrm{e}-10$ & $6.18 \mathrm{e}-10$ & $7.22 \mathrm{e}-10$ & $7.11 \mathrm{e}-10$ & $6.18 \mathrm{e}-10$ & $7.22 \mathrm{e}-10$ & $7.11 \mathrm{e}-10$ \\
\hline Stock-Wright S Stat. P-val & $7.31 \mathrm{e}-06$ & $7.13 e-06$ & $7.06 \mathrm{e}-06$ & $7.31 \mathrm{e}-06$ & $7.13 e-06$ & $7.06 \mathrm{e}-06$ & 7.31e-06 & $7.13 e-06$ & $7.06 \mathrm{e}-06$ \\
\hline Observations & $1,657,232$ & $1,623,441$ & $1,623,435$ & $1,657,232$ & $1,623,441$ & $1,623,435$ & $1,657,232$ & $1,623,441$ & $1,623,435$ \\
\hline
\end{tabular}

Notes: This table presents the instrumental variable estimation of the effect of air pollution on hospitalization rate within a 25-mile radius of CA ports, jointly estimated for multiple air pollutants. Each column in a panel presents an individual regression on a set of pollutants. Pollution concentrations are instrumented by fitted vessel tonnage in ports, wind speed, relative wind direction between a zip code-port pair, and interaction terms. All regressions include weather controls and their quadratic terms, such as the quadratics of maximum temperature, minimum temperature, dew point temperature, and precipitation. All regressions also include county-by-year, month, day-of-week, holiday, and zip code-port pair fixed effects. An observation is a zip code-portday. Standard errors are clustered by zip code-port pair and day. Estimates are weighted by the zip code-specific population. Significance levels are indicated by ${ }^{* *} 1 \%,{ }^{* *} 5 \%$, and ${ }^{*} 10 \%$. 
Table A.28: Effect of air pollution on hospitalization rates in California port areas - joint estimation with zip codes within a 15-mile radius from ports

\begin{tabular}{|c|c|c|c|c|c|c|c|c|c|}
\hline & \multicolumn{9}{|c|}{ Dependent variable: hospital visits/million residents } \\
\hline & \multicolumn{3}{|c|}{ All Respiratory } & \multicolumn{3}{|c|}{ All Heart } & \multicolumn{3}{|c|}{ All Psychiatric } \\
\hline & $(1)$ & $(2)$ & (3) & $(4)$ & $(5)$ & $(6)$ & $(7)$ & $(8)$ & $(9)$ \\
\hline \multicolumn{10}{|c|}{ Panel A: Overall population } \\
\hline $\mathrm{CO}(\mathrm{ppb})$ & $\begin{array}{c}0.10^{* * *} \\
(0.03)\end{array}$ & $\begin{array}{l}0.07^{* * *} \\
(0.02)\end{array}$ & $\begin{array}{l}0.11^{* * *} \\
(0.03)\end{array}$ & $\begin{array}{c}0.01 \\
(0.01)\end{array}$ & $\begin{array}{c}0.01^{*} \\
(0.005)\end{array}$ & $\begin{array}{c}0.01 \\
(0.01)\end{array}$ & $\begin{array}{c}-0.004 \\
(0.01)\end{array}$ & $\begin{array}{l}0.002 \\
(0.01)\end{array}$ & $\begin{array}{c}-0.003 \\
(0.01)\end{array}$ \\
\hline $\mathrm{NO}_{2}(\mathrm{ppb})$ & $\begin{array}{c}-1.33^{* *} \\
(0.62)\end{array}$ & & $\begin{array}{c}-1.88^{* *} \\
(0.92)\end{array}$ & $\begin{array}{c}0.10 \\
(0.18)\end{array}$ & & $\begin{array}{l}-0.10 \\
(0.35)\end{array}$ & $\begin{array}{l}0.46^{* *} \\
(0.20)\end{array}$ & & $\begin{array}{c}0.25 \\
(0.38)\end{array}$ \\
\hline $\mathrm{SO}_{2}(\mathrm{ppb})$ & & $\begin{array}{c}-12.89 \\
(9.30)\end{array}$ & $\begin{array}{c}10.60 \\
(13.82)\end{array}$ & & $\begin{array}{c}2.36 \\
(2.59)\end{array}$ & $\begin{array}{c}3.57 \\
(4.97)\end{array}$ & & $\begin{array}{l}7.34^{* * *} \\
(2.82)\end{array}$ & $\begin{array}{c}4.22 \\
(5.23)\end{array}$ \\
\hline Observations & 869,585 & 861,925 & 861,918 & 869,585 & 861,925 & 861,918 & 869,585 & 861,925 & 861,918 \\
\hline \multicolumn{10}{|l|}{ Panel B: Black } \\
\hline $\mathrm{CO}(\mathrm{ppb})$ & $\begin{array}{c}0.05 \\
(0.06)\end{array}$ & $\begin{array}{c}0.05 \\
(0.03)\end{array}$ & $\begin{array}{l}0.14^{*} \\
(0.07)\end{array}$ & $\begin{array}{c}0.01 \\
(0.02)\end{array}$ & $\begin{array}{c}0.01 \\
(0.01)\end{array}$ & $\begin{array}{c}0.01 \\
(0.03)\end{array}$ & $\begin{array}{l}-0.04 \\
(0.03)\end{array}$ & $\begin{array}{l}-0.02 \\
(0.02)\end{array}$ & $\begin{array}{l}-0.02 \\
(0.03)\end{array}$ \\
\hline $\mathrm{NO}_{2}(\mathrm{ppb})$ & $\begin{array}{c}1.96 \\
(1.68)\end{array}$ & & $\begin{array}{l}-4.36 \\
(2.90)\end{array}$ & $\begin{array}{c}0.38 \\
(0.67)\end{array}$ & & $\begin{array}{c}0.02 \\
(1.06)\end{array}$ & $\begin{array}{c}1.36^{*} \\
(0.70)\end{array}$ & & $\begin{array}{l}-0.22 \\
(1.36)\end{array}$ \\
\hline $\mathrm{SO}_{2}(\mathrm{ppb})$ & & $\begin{array}{l}53.60^{* *} \\
(22.92)\end{array}$ & $\begin{array}{c}106.91^{* * *} \\
(38.16)\end{array}$ & & $\begin{array}{c}6.57 \\
(9.49)\end{array}$ & $\begin{array}{c}6.30 \\
(14.84)\end{array}$ & & $\begin{array}{c}24.63^{* *} \\
(9.81)\end{array}$ & $\begin{array}{c}27.36 \\
(18.90)\end{array}$ \\
\hline Observations & 560,978 & 556,105 & 556,103 & 560,978 & 556,105 & 556,103 & 560,978 & 556,105 & 556,103 \\
\hline \multicolumn{10}{|l|}{ Panel C: White } \\
\hline $\mathrm{CO}(\mathrm{ppb})$ & $\begin{array}{c}0.11^{* * *} \\
(0.02)\end{array}$ & $\begin{array}{l}0.07^{* * *} \\
(0.02)\end{array}$ & $\begin{array}{l}0.12^{* * *} \\
(0.03)\end{array}$ & $\begin{array}{l}0.03^{* *} \\
(0.01)\end{array}$ & $\begin{array}{l}0.02^{* *} \\
(0.01)\end{array}$ & $\begin{array}{c}0.02 \\
(0.02)\end{array}$ & $\begin{array}{c}0.01 \\
(0.02)\end{array}$ & $\begin{array}{c}0.01 \\
(0.01)\end{array}$ & $\begin{array}{c}0.01 \\
(0.02)\end{array}$ \\
\hline $\mathrm{NO}_{2}(\mathrm{ppb})$ & $\begin{array}{c}-1.82^{* * *} \\
(0.54)\end{array}$ & & $\begin{array}{l}-2.07^{* *} \\
(0.90)\end{array}$ & $\begin{array}{l}-0.43 \\
(0.33)\end{array}$ & & $\begin{array}{c}0.16 \\
(0.65)\end{array}$ & $\begin{array}{c}0.14 \\
(0.37)\end{array}$ & & $\begin{array}{c}0.33 \\
(0.71)\end{array}$ \\
\hline $\mathrm{SO}_{2}(\mathrm{ppb})$ & & $\begin{array}{c}-19.70^{* *} \\
(7.93)\end{array}$ & $\begin{array}{c}5.25 \\
(13.55) \\
\end{array}$ & & $\begin{array}{l}-6.71 \\
(4.71)\end{array}$ & $\begin{array}{l}-8.62 \\
(9.36)\end{array}$ & & $\begin{array}{c}1.82 \\
(5.26)\end{array}$ & $\begin{array}{c}-2.20 \\
(10.03)\end{array}$ \\
\hline Observations & 805,806 & 798,316 & 798,310 & 805,806 & 798,316 & 798,310 & 805,806 & 798,316 & 798,310 \\
\hline
\end{tabular}

Notes: This table presents the instrumental variable estimation of the effect of air pollution on hospitalization rate within a 15-mile radius of CA ports, jointly estimated for multiple air pollutants. Each column in a panel presents an individual regression on a set of pollutants. Pollution concentrations are instrumented by fitted vessel tonnage in ports, wind speed, relative wind direction between a zip code-port pair, and interaction terms. All regressions include weather controls and their quadratic terms, such as the quadratics of maximum temperature, minimum temperature, dew point temperature, and precipitation. All regressions also include county-by-year, month, day-of-week, holiday, and zip code-port pair fixed effects. An observation is a zip code-port-day. Standard errors are clustered by zip code-port pair and day. Estimates are weighted by the zip code-specific population. Significance levels are indicated by ** $1 \%, * * 5 \%$, and $* 10 \%$. 
Table A.29: Effect of fitted vessel tonnage on highway congestion in California port areas

\begin{tabular}{|c|c|c|c|c|c|c|}
\hline & \multicolumn{6}{|c|}{ Dependent variable: traffic delay with respect to threshold speed } \\
\hline & $\begin{array}{c}35 \mathrm{mph} \\
(1) \\
\end{array}$ & $\begin{array}{c}40 \mathrm{mph} \\
(2)\end{array}$ & $\begin{array}{c}45 \mathrm{mph} \\
(3) \\
\end{array}$ & $\begin{array}{c}50 \mathrm{mph} \\
(4) \\
\end{array}$ & $\begin{array}{c}55 \mathrm{mph} \\
(5) \\
\end{array}$ & $\begin{array}{c}60 \mathrm{mph} \\
(6)\end{array}$ \\
\hline \multicolumn{7}{|l|}{ Panel A: Vessel tonnage } \\
\hline Fitted Vessel Tonnage & $\begin{array}{c}0.17 \\
(0.32)\end{array}$ & $\begin{array}{c}0.22 \\
(0.36)\end{array}$ & $\begin{array}{c}0.24 \\
(0.40)\end{array}$ & $\begin{array}{c}0.15 \\
(0.43)\end{array}$ & $\begin{array}{l}-0.10 \\
(0.48)\end{array}$ & $\begin{array}{l}-0.47 \\
(0.52)\end{array}$ \\
\hline $\begin{array}{l}\text { Adjusted } R^{2} \\
\text { Observations }\end{array}$ & $\begin{array}{c}0.33 \\
2,618,707\end{array}$ & $\begin{array}{c}0.35 \\
2,618,707\end{array}$ & $\begin{array}{c}0.37 \\
2,618,707\end{array}$ & $\begin{array}{c}0.39 \\
2,618,707\end{array}$ & $\begin{array}{c}0.42 \\
2,618,707\end{array}$ & $\begin{array}{c}0.44 \\
2,618,707\end{array}$ \\
\hline \multicolumn{7}{|l|}{ Panel B: Vessel counts } \\
\hline Fitted Vessel Counts & $\begin{array}{l}-0.04 \\
(0.09)\end{array}$ & $\begin{array}{l}-0.03 \\
(0.10)\end{array}$ & $\begin{array}{l}-0.02 \\
(0.11)\end{array}$ & $\begin{array}{l}-0.03 \\
(0.12)\end{array}$ & $\begin{array}{l}-0.07 \\
(0.13)\end{array}$ & $\begin{array}{l}-0.13 \\
(0.13)\end{array}$ \\
\hline $\begin{array}{l}\text { Adjusted } R^{2} \\
\text { Observations }\end{array}$ & $\begin{array}{c}0.33 \\
2,618,707\end{array}$ & $\begin{array}{c}0.35 \\
2,618,707\end{array}$ & $\begin{array}{c}0.37 \\
2,618,707\end{array}$ & $\begin{array}{c}0.39 \\
2,618,707\end{array}$ & $\begin{array}{c}0.42 \\
2,618,707\end{array}$ & $\begin{array}{c}0.44 \\
2,618,707\end{array}$ \\
\hline
\end{tabular}

Notes: This table presents the OLS estimation for the effect of fitted vessel tonnage and counts on highway congestion in California's port areas. The fitted values are obtained from regressing log vessel tonnage or vessel counts on the instrumet of seven-day lagged and 500-mile distant cyclones from ports. The dependent variable is measured as average delays to a threshold speed. Each column presents a regression of threshold speed. All regressions include weather controls (i.e., the quadratics of maximum temperature, minimum temperature, dew point temperature, precipitation, and wind direction) and fixed effects (i.e., county-by-year, month, day-of-week, holiday, freeway, and VDS-port). An observation is a VDS-port-day. Standard errors are clustered by VDS-port and day. Significance levels are indicated by $* * * 1 \%, * * 5$, and $* 10 \%$. 
Table A.30: Effect of air pollution on hospitalization rates in California port areas, excluding strong windy days

\begin{tabular}{|c|c|c|c|c|c|c|}
\hline & \multicolumn{6}{|c|}{ Dependent variable: hospital visits/million residents } \\
\hline & \multicolumn{3}{|c|}{ Respiratory } & \multirow{2}{*}{$\begin{array}{c}\text { Heart } \\
\text { All } \\
\text { Heart } \\
(4)\end{array}$} & \multicolumn{2}{|c|}{ Psychiatric } \\
\hline & $\begin{array}{c}\text { Asthma } \\
\text { (1) }\end{array}$ & $\begin{array}{c}\text { Upper } \\
\text { Respiratory } \\
\text { (2) }\end{array}$ & $\begin{array}{c}\text { All } \\
\text { Respiratory } \\
\text { (3) }\end{array}$ & & $\begin{array}{c}\text { Anxiety } \\
\text { (5) }\end{array}$ & $\begin{array}{c}\text { All } \\
\text { Psychiatric } \\
\text { (6) }\end{array}$ \\
\hline \multicolumn{7}{|c|}{ Panel A: Overall population } \\
\hline $\mathrm{CO}(\mathrm{ppb})$ & $\begin{array}{l}0.01^{* * *} \\
(0.002)\end{array}$ & $\begin{array}{l}0.01^{* * *} \\
(0.003)\end{array}$ & $\begin{array}{l}0.04^{* * *} \\
(0.01)\end{array}$ & $\begin{array}{l}0.01^{* * *} \\
(0.003)\end{array}$ & $\begin{array}{l}0.003^{* *} \\
(0.001)\end{array}$ & $\begin{array}{c}0.01^{* *} \\
(0.003)\end{array}$ \\
\hline $\mathrm{NO}_{2}(\mathrm{ppb})$ & $\begin{array}{l}0.30^{* * *} \\
(0.05)\end{array}$ & $\begin{array}{l}0.30^{* * *} \\
(0.08)\end{array}$ & $\begin{array}{l}1.07^{* * *} \\
(0.20)\end{array}$ & $\begin{array}{l}0.37^{* * *} \\
(0.08)\end{array}$ & $\begin{array}{l}0.09^{* * *} \\
(0.03)\end{array}$ & $\begin{array}{l}0.22^{* * *} \\
(0.08)\end{array}$ \\
\hline $\mathrm{PM}_{2.5}\left(\mu \mathrm{g} / \mathrm{m}^{3}\right)$ & $\begin{array}{l}0.34^{* * *} \\
(0.06)\end{array}$ & $\begin{array}{l}0.36^{* * *} \\
(0.09)\end{array}$ & $\begin{array}{l}1.26^{* * *} \\
(0.25)\end{array}$ & $\begin{array}{l}0.39^{* * *} \\
(0.09)\end{array}$ & $\begin{array}{l}0.10^{* * *} \\
(0.04)\end{array}$ & $\begin{array}{l}0.23^{* *} \\
(0.09)\end{array}$ \\
\hline $\mathrm{SO}_{2}(\mathrm{ppb})$ & $\begin{array}{l}7.84^{* * *} \\
(1.42)\end{array}$ & $\begin{array}{l}7.19^{* * *} \\
(2.09)\end{array}$ & $\begin{array}{l}27.48^{* * *} \\
(5.61)\end{array}$ & $\begin{array}{c}10.20^{* * *} \\
(2.14)\end{array}$ & $\begin{array}{l}2.86^{* * *} \\
(0.88)\end{array}$ & $\begin{array}{l}6.72^{* * *} \\
(2.13)\end{array}$ \\
\hline \multicolumn{7}{|l|}{ Panel B: Black } \\
\hline $\mathrm{CO}(\mathrm{ppb})$ & $\begin{array}{l}0.03^{* * *} \\
(0.01)\end{array}$ & $\begin{array}{l}0.03^{* * *} \\
(0.01)\end{array}$ & $\begin{array}{l}0.09^{* * *} \\
(0.02)\end{array}$ & $\begin{array}{l}0.03^{* * *} \\
(0.01)\end{array}$ & $\begin{array}{c}0.003 \\
(0.004)\end{array}$ & $\begin{array}{c}0.0002 \\
(0.01)\end{array}$ \\
\hline $\mathrm{NO}_{2}(\mathrm{ppb})$ & $\begin{array}{l}0.87^{* * *} \\
(0.22)\end{array}$ & $\begin{array}{l}0.85^{* * *} \\
(0.18)\end{array}$ & $\begin{array}{l}2.64^{* * *} \\
(0.52)\end{array}$ & $\begin{array}{l}0.83^{* * *} \\
(0.23)\end{array}$ & $\begin{array}{c}0.15 \\
(0.10)\end{array}$ & $\begin{array}{c}0.12 \\
(0.23)\end{array}$ \\
\hline $\mathrm{PM}_{2.5}\left(\mu \mathrm{g} / \mathrm{m}^{3}\right)$ & $\begin{array}{l}1.03^{* * *} \\
(0.24)\end{array}$ & $\begin{array}{l}0.98^{* * *} \\
(0.21)\end{array}$ & $\begin{array}{l}3.20^{* * *} \\
(0.59)\end{array}$ & $\begin{array}{l}0.79^{* * *} \\
(0.26)\end{array}$ & $\begin{array}{c}0.07 \\
(0.11)\end{array}$ & $\begin{array}{l}-0.04 \\
(0.25)\end{array}$ \\
\hline $\mathrm{SO}_{2}(\mathrm{ppb})$ & $\begin{array}{c}22.96^{* * *} \\
(5.53)\end{array}$ & $\begin{array}{c}26.00^{* * *} \\
(4.87)\end{array}$ & $\begin{array}{l}76.31^{* * *} \\
(13.50)\end{array}$ & $\begin{array}{c}22.42^{* * *} \\
(6.06)\end{array}$ & $\begin{array}{l}5.42^{* *} \\
(2.71)\end{array}$ & $\begin{array}{c}6.33 \\
(5.99)\end{array}$ \\
\hline \multicolumn{7}{|l|}{ Panel C: White } \\
\hline $\mathrm{CO}(\mathrm{ppb})$ & $\begin{array}{l}0.01^{* * *} \\
(0.003)\end{array}$ & $\begin{array}{l}0.01^{* * *} \\
(0.002)\end{array}$ & $\begin{array}{l}0.04^{* * *} \\
(0.01)\end{array}$ & $\begin{array}{l}0.02^{* * *} \\
(0.01)\end{array}$ & $\begin{array}{c}0.002 \\
(0.003)\end{array}$ & $\begin{array}{l}0.01^{*} \\
(0.01)\end{array}$ \\
\hline $\mathrm{NO}_{2}(\mathrm{ppb})$ & $\begin{array}{l}0.28^{* * *} \\
(0.06)\end{array}$ & $\begin{array}{l}0.15^{* * *} \\
(0.05)\end{array}$ & $\begin{array}{l}0.94^{* * *} \\
(0.18)\end{array}$ & $\begin{array}{l}0.46^{* * *} \\
(0.14)\end{array}$ & $\begin{array}{c}0.05 \\
(0.06)\end{array}$ & $\begin{array}{l}0.30^{* *} \\
(0.15)\end{array}$ \\
\hline $\mathrm{PM}_{2.5}\left(\mu \mathrm{g} / \mathrm{m}^{3}\right)$ & $\begin{array}{l}0.34^{* * *} \\
(0.08)\end{array}$ & $\begin{array}{l}0.19^{* * *} \\
(0.06)\end{array}$ & $\begin{array}{l}1.13^{* * *} \\
(0.24)\end{array}$ & $\begin{array}{l}0.55^{* * *} \\
(0.18)\end{array}$ & $\begin{array}{c}0.07 \\
(0.08)\end{array}$ & $\begin{array}{l}0.37^{* *} \\
(0.19)\end{array}$ \\
\hline $\mathrm{SO}_{2}(\mathrm{ppb})$ & $\begin{array}{l}6.51^{* * *} \\
(1.62)\end{array}$ & $\begin{array}{l}3.11^{* *} \\
(1.22)\end{array}$ & $\begin{array}{l}20.45^{* * *} \\
(4.66)\end{array}$ & $\begin{array}{l}11.16^{* * *} \\
(3.63)\end{array}$ & $\begin{array}{c}2.21 \\
(1.60)\end{array}$ & $\begin{array}{l}9.18^{* *} \\
(3.80)\end{array}$ \\
\hline
\end{tabular}

Notes: This table presents the instrumental variable estimation of the effect of air pollution on hospitalization rate, where the observations with wind speed greater than 3.3 meters per second are excluded. Each entry presents an individual regression of an air pollutant on an illness category. Pollution concentrations are instrumented by fitted vessel tonnage in ports, wind direction, wind speed, and their interactions. All regressions include weather controls, such as the quadratics of maximum temperature, minimum temperature, dew point temperature, and precipitation. All regressions also include county-by-year, month, day-of-week, holiday, and zip code-port pair fixed effects. An observation is a zip code-port-day. Standard errors are clustered by zip code-port pair and day. Estimates are weighted by the zip code-specific population. Significance levels are indicated by ${ }^{* * *} 1 \%$, ${ }^{* *} 5 \%$, and ${ }^{*} 10 \%$. 
Table A.31: Effect of air pollution on hospitalizaton rates in California port areas, principal diagnoses

\begin{tabular}{|c|c|c|c|}
\hline & \multicolumn{3}{|c|}{ Dependent variable: hospital visits/million residents } \\
\hline & $\begin{array}{c}\text { All } \\
\text { Respiratory } \\
(1)\end{array}$ & $\begin{array}{c}\text { All } \\
\text { Heart } \\
(2) \\
\end{array}$ & $\begin{array}{c}\text { All } \\
\text { Psychiatric } \\
(3)\end{array}$ \\
\hline \multicolumn{4}{|c|}{ Panel A: Overall population } \\
\hline $\mathrm{CO}(\mathrm{ppb})$ & $\begin{array}{l}0.02^{* * *} \\
(0.01)\end{array}$ & $\begin{array}{l}0.004^{* * *} \\
(0.001)\end{array}$ & $\begin{array}{l}0.002^{*} \\
(0.001)\end{array}$ \\
\hline $\mathrm{NO}_{2}(\mathrm{ppb})$ & $\begin{array}{l}0.65^{* * *} \\
(0.15)\end{array}$ & $\begin{array}{l}0.09^{* * *} \\
(0.02)\end{array}$ & $\begin{array}{l}0.06^{* * *} \\
(0.02)\end{array}$ \\
\hline $\mathrm{PM}_{2.5}\left(\mu \mathrm{g} / \mathrm{m}^{3}\right)$ & $\begin{array}{l}0.92^{* * *} \\
(0.18)\end{array}$ & $\begin{array}{l}0.10^{* * *} \\
(0.03)\end{array}$ & $\begin{array}{c}0.04 \\
(0.03)\end{array}$ \\
\hline $\mathrm{SO}_{2}(\mathrm{ppb})$ & $\begin{array}{c}17.18^{* * *} \\
(4.78)\end{array}$ & $\begin{array}{l}2.35^{* * *} \\
(0.79)\end{array}$ & $\begin{array}{l}1.61^{* *} \\
(0.70)\end{array}$ \\
\hline \multicolumn{4}{|l|}{ Panel B: Black } \\
\hline $\mathrm{CO}(\mathrm{ppb})$ & $\begin{array}{l}0.05^{* * *} \\
(0.01)\end{array}$ & $\begin{array}{c}0.005 \\
(0.003)\end{array}$ & $\begin{array}{l}-0.002 \\
(0.004)\end{array}$ \\
\hline $\mathrm{NO}_{2}(\mathrm{ppb})$ & $\begin{array}{l}1.56^{* * *} \\
(0.30)\end{array}$ & $\begin{array}{c}0.10 \\
(0.08)\end{array}$ & $\begin{array}{l}-0.02 \\
(0.10)\end{array}$ \\
\hline $\mathrm{PM}_{2.5}\left(\mu \mathrm{g} / \mathrm{m}^{3}\right)$ & $\begin{array}{l}1.91^{* * *} \\
(0.37)\end{array}$ & $\begin{array}{l}0.17^{*} \\
(0.10)\end{array}$ & $\begin{array}{l}-0.08 \\
(0.12)\end{array}$ \\
\hline $\mathrm{SO}_{2}(\mathrm{ppb})$ & $\begin{array}{l}49.29^{* * *} \\
(8.62)\end{array}$ & $\begin{array}{c}1.83 \\
(2.29)\end{array}$ & $\begin{array}{c}0.88 \\
(2.57)\end{array}$ \\
\hline \multicolumn{4}{|l|}{ Panel C: White } \\
\hline $\mathrm{CO}(\mathrm{ppb})$ & $\begin{array}{l}0.02^{* * *} \\
(0.005)\end{array}$ & $\begin{array}{l}0.004^{* *} \\
(0.002)\end{array}$ & $\begin{array}{l}0.003^{*} \\
(0.002)\end{array}$ \\
\hline $\mathrm{NO}_{2}(\mathrm{ppb})$ & $\begin{array}{l}0.37^{* * *} \\
(0.11)\end{array}$ & $\begin{array}{l}0.09^{*} \\
(0.05)\end{array}$ & $\begin{array}{l}0.09^{* *} \\
(0.04)\end{array}$ \\
\hline $\mathrm{PM}_{2.5}\left(\mu \mathrm{g} / \mathrm{m}^{3}\right)$ & $\begin{array}{l}0.45^{* * *} \\
(0.15)\end{array}$ & $\begin{array}{l}0.13^{* *} \\
(0.06)\end{array}$ & $\begin{array}{l}0.12^{* *} \\
(0.05)\end{array}$ \\
\hline $\mathrm{SO}_{2}(\mathrm{ppb})$ & $\begin{array}{l}7.85^{* * *} \\
(2.79)\end{array}$ & $\begin{array}{c}1.89 \\
(1.20)\end{array}$ & $\begin{array}{l}2.30^{* *} \\
(0.99)\end{array}$ \\
\hline
\end{tabular}

Notes: This table presents the instrumental variable estimation of the effect of air pollution on hospitalization rates for the overall population, Blacks, and whites, where hospitalization rates are calculated only using principal diagnoses. Each entry presents an individual regression of an air pollutant on an illness category. Pollution concentrations are instrumented by fitted vessel tonnage in ports, wind direction, wind speed, and their interactions. All regressions include weather controls, such as the quadratics of maximum temperature, minimum temperature, dew point temperature, and precipitation. All regressions also include county-by-year, month, day-of-week, holiday, and zip code-port pair fixed effects. An observation is a zip code-port-day. Standard errors are clustered by zip code-port pair and day. Estimates are weighted by the zip code-specific population. Significance levels are indicated by ${ }^{* * *} 1 \%,{ }^{* *} 5 \%$, and ${ }^{*} 10 \%$. 
Table A.32: Effect of air pollution on hospitalization rates in California port areas, Patient Discharge Data

\begin{tabular}{|c|c|c|c|}
\hline & \multicolumn{3}{|c|}{ Dependent variable: hospital visits/million residents } \\
\hline & $\begin{array}{c}\text { All } \\
\text { Respiratory } \\
(1) \\
\end{array}$ & $\begin{array}{c}\text { All } \\
\text { Heart } \\
(2) \\
\end{array}$ & $\begin{array}{c}\text { All } \\
\text { Psychiatric } \\
(3)\end{array}$ \\
\hline \multicolumn{4}{|c|}{ Panel A: Overall population } \\
\hline $\mathrm{CO}(\mathrm{ppb})$ & $\begin{array}{l}0.01^{* * *} \\
(0.002)\end{array}$ & $\begin{array}{l}0.01^{* * *} \\
(0.002)\end{array}$ & $\begin{array}{l}0.004^{* *} \\
(0.002)\end{array}$ \\
\hline $\mathrm{NO}_{2}(\mathrm{ppb})$ & $\begin{array}{l}0.23^{* * *} \\
(0.05)\end{array}$ & $\begin{array}{l}0.20^{* * *} \\
(0.04)\end{array}$ & $\begin{array}{l}0.12^{* * *} \\
(0.04)\end{array}$ \\
\hline $\mathrm{PM}_{2.5}\left(\mu \mathrm{g} / \mathrm{m}^{3}\right)$ & $\begin{array}{l}0.31^{* * *} \\
(0.06)\end{array}$ & $\begin{array}{l}0.22^{* * *} \\
(0.05)\end{array}$ & $\begin{array}{l}0.13^{* * *} \\
(0.04)\end{array}$ \\
\hline $\mathrm{SO}_{2}(\mathrm{ppb})$ & $\begin{array}{l}5.58^{* * *} \\
(1.61)\end{array}$ & $\begin{array}{l}5.66^{* * *} \\
(1.36)\end{array}$ & $\begin{array}{l}4.15^{* * *} \\
(1.22)\end{array}$ \\
\hline \multicolumn{4}{|l|}{ Panel B: Black } \\
\hline $\mathrm{CO}(\mathrm{ppb})$ & $\begin{array}{l}0.02^{* *} \\
(0.01)\end{array}$ & $\begin{array}{l}0.01^{* *} \\
(0.01)\end{array}$ & $\begin{array}{c}0.004 \\
(0.005)\end{array}$ \\
\hline $\mathrm{NO}_{2}(\mathrm{ppb})$ & $\begin{array}{l}0.43^{* *} \\
(0.17)\end{array}$ & $\begin{array}{l}0.37^{* *} \\
(0.14)\end{array}$ & $\begin{array}{c}0.17 \\
(0.13)\end{array}$ \\
\hline $\mathrm{PM}_{2.5}\left(\mu \mathrm{g} / \mathrm{m}^{3}\right)$ & $\begin{array}{l}0.61^{* * *} \\
(0.22)\end{array}$ & $\begin{array}{l}0.40^{* *} \\
(0.18)\end{array}$ & $\begin{array}{c}0.17 \\
(0.15)\end{array}$ \\
\hline $\mathrm{SO}_{2}(\mathrm{ppb})$ & $\begin{array}{c}13.31^{* * *} \\
(4.96)\end{array}$ & $\begin{array}{l}8.48^{* *} \\
(3.95)\end{array}$ & $\begin{array}{l}6.69^{*} \\
(3.43) \\
\end{array}$ \\
\hline \multicolumn{4}{|l|}{ Panel C: White } \\
\hline $\mathrm{CO}(\mathrm{ppb})$ & $\begin{array}{l}0.01^{* * *} \\
(0.004)\end{array}$ & $\begin{array}{l}0.01^{* * *} \\
(0.003)\end{array}$ & $\begin{array}{l}0.01^{* *} \\
(0.003)\end{array}$ \\
\hline $\mathrm{NO}_{2}(\mathrm{ppb})$ & $\begin{array}{l}0.26^{* * *} \\
(0.08)\end{array}$ & $\begin{array}{l}0.26^{* * *} \\
(0.07)\end{array}$ & $\begin{array}{l}0.19^{* *} \\
(0.08)\end{array}$ \\
\hline $\mathrm{PM}_{2.5}\left(\mu \mathrm{g} / \mathrm{m}^{3}\right)$ & $\begin{array}{l}0.39^{* * *} \\
(0.12)\end{array}$ & $\begin{array}{l}0.37^{* * *} \\
(0.11)\end{array}$ & $\begin{array}{l}0.26^{* *} \\
(0.11)\end{array}$ \\
\hline $\mathrm{SO}_{2}(\mathrm{ppb})$ & $\begin{array}{l}4.64^{* *} \\
(2.12)\end{array}$ & $\begin{array}{l}4.97^{* *} \\
(2.02)\end{array}$ & $\begin{array}{l}4.85^{* *} \\
(1.99)\end{array}$ \\
\hline
\end{tabular}

Notes: This table presents the instrumental variable estimation of the effect of air pollution on hospitalization rates for the overall population, Blacks, and whites, where hospitalization rates are calculated only using the Patient Discharge Data. Each entry presents an individual regression of an air pollutant on an illness category. Pollution concentrations are instrumented by fitted vessel tonnage in ports, wind direction, wind speed, and their interactions. All regressions include weather controls, such as the quadratics of maximum temperature, minimum temperature, dew point temperature, and precipitation. All regressions also include county-byyear, month, day-of-week, holiday, and zip code-port pair fixed effects. An observation is a zip code-port-day. Standard errors are clustered by zip code-port pair and day. Estimates are weighted by the zip code-specific population. Significance levels are indicated by $* * * 1 \%,{ }^{* *} 5 \%$, and $* 10 \%$. 
Table A.33: Effect of air pollution on hospitalization rates in California port areas, Emergency Department Data

\begin{tabular}{|c|c|c|c|}
\hline & \multicolumn{3}{|c|}{ Dependent variable: hospital visits/million residents } \\
\hline & $\begin{array}{c}\text { All } \\
\text { Respiratory } \\
(1) \\
\end{array}$ & $\begin{array}{c}\text { All } \\
\text { Heart } \\
(2) \\
\end{array}$ & $\begin{array}{c}\text { All } \\
\text { Psychiatric } \\
(3)\end{array}$ \\
\hline \multicolumn{4}{|c|}{ Panel A: Overall population } \\
\hline $\mathrm{CO}(\mathrm{ppb})$ & $\begin{array}{l}0.03^{* * *} \\
(0.01)\end{array}$ & $\begin{array}{l}0.01^{* * *} \\
(0.001)\end{array}$ & $\begin{array}{l}0.01^{* * *} \\
(0.002)\end{array}$ \\
\hline $\mathrm{NO}_{2}(\mathrm{ppb})$ & $\begin{array}{l}0.87^{* * *} \\
(0.18)\end{array}$ & $\begin{array}{l}0.16^{* * *} \\
(0.03)\end{array}$ & $\begin{array}{l}0.14^{* * *} \\
(0.04)\end{array}$ \\
\hline $\mathrm{PM}_{2.5}\left(\mu \mathrm{g} / \mathrm{m}^{3}\right)$ & $\begin{array}{l}1.19^{* * *} \\
(0.22)\end{array}$ & $\begin{array}{l}0.15^{* * *} \\
(0.03)\end{array}$ & $\begin{array}{l}0.11^{* *} \\
(0.05)\end{array}$ \\
\hline $\mathrm{SO}_{2}(\mathrm{ppb})$ & $\begin{array}{l}26.26^{* * *} \\
(6.03)\end{array}$ & $\begin{array}{l}5.15^{* * *} \\
(0.91)\end{array}$ & $\begin{array}{l}3.71^{* * *} \\
(1.39)\end{array}$ \\
\hline \multicolumn{4}{|l|}{ Panel B: Black } \\
\hline $\mathrm{CO}(\mathrm{ppb})$ & $\begin{array}{l}0.08^{* * *} \\
(0.02)\end{array}$ & $\begin{array}{l}0.01^{* *} \\
(0.005)\end{array}$ & $\begin{array}{c}-0.004 \\
(0.01)\end{array}$ \\
\hline $\mathrm{NO}_{2}(\mathrm{ppb})$ & $\begin{array}{l}2.35^{* * *} \\
(0.42)\end{array}$ & $\begin{array}{l}0.29^{* *} \\
(0.12)\end{array}$ & $\begin{array}{l}-0.11 \\
(0.16)\end{array}$ \\
\hline $\mathrm{PM}_{2.5}\left(\mu \mathrm{g} / \mathrm{m}^{3}\right)$ & $\begin{array}{l}2.91^{* * *} \\
(0.51)\end{array}$ & $\begin{array}{l}0.28^{*} \\
(0.15)\end{array}$ & $\begin{array}{l}-0.26 \\
(0.20)\end{array}$ \\
\hline $\mathrm{SO}_{2}(\mathrm{ppb})$ & $\begin{array}{c}74.36^{* * *} \\
(11.84)\end{array}$ & $\begin{array}{l}8.43^{* *} \\
(3.43)\end{array}$ & $\begin{array}{l}-2.21 \\
(4.63)\end{array}$ \\
\hline \multicolumn{4}{|l|}{ Panel C: White } \\
\hline $\mathrm{CO}(\mathrm{ppb})$ & $\begin{array}{l}0.03^{* * *} \\
(0.01)\end{array}$ & $\begin{array}{l}0.01^{* * *} \\
(0.002)\end{array}$ & $\begin{array}{l}0.01^{*} \\
(0.003)\end{array}$ \\
\hline $\mathrm{NO}_{2}(\mathrm{ppb})$ & $\begin{array}{l}0.58^{* * *} \\
(0.12)\end{array}$ & $\begin{array}{l}0.16^{* * *} \\
(0.05)\end{array}$ & $\begin{array}{l}0.14^{*} \\
(0.07)\end{array}$ \\
\hline $\mathrm{PM}_{2.5}\left(\mu \mathrm{g} / \mathrm{m}^{3}\right)$ & $\begin{array}{l}0.70^{* * *} \\
(0.17)\end{array}$ & $\begin{array}{l}0.19^{* * *} \\
(0.07)\end{array}$ & $\begin{array}{c}0.17 \\
(0.11)\end{array}$ \\
\hline $\mathrm{SO}_{2}(\mathrm{ppb})$ & $\begin{array}{l}14.15^{* * *} \\
(3.23)\end{array}$ & $\begin{array}{l}5.00^{* * *} \\
(1.32)\end{array}$ & $\begin{array}{l}4.32^{* *} \\
(1.93)\end{array}$ \\
\hline
\end{tabular}

Notes: This table presents the instrumental variable estimation of the effect of air pollution on hospitalization rates for the overall population, Blacks, and whites, where hospitalization rates are calculated only using the Emergency Department Data. Each entry presents an individual regression of an air pollutant on an illness category. Pollution concentrations are instrumented by fitted vessel tonnage in ports, wind direction, wind speed, and their interactions. All regressions include weather controls, such as the quadratics of maximum temperature, minimum temperature, dew point temperature, and precipitation. All regressions also include county-by-year, month, day-of-week, holiday, and zip code-port pair fixed effects. An observation is a zip code-port-day. Standard errors are clustered by zip code-port pair and day. Estimates are weighted by the zip code-specific population. Significance levels are indicated by ${ }^{* * *} 1 \%,{ }^{* *} 5 \%$, and ${ }^{*} 10 \%$. 
Table A.34: Effect of air pollution on hospitalization rates in California port areas, Ambulatory Surgery Center Data

\begin{tabular}{|c|c|c|c|}
\hline & \multicolumn{3}{|c|}{ Dependent variable: hospital visits/million residents } \\
\hline & $\begin{array}{c}\text { All } \\
\text { Respiratory } \\
(1) \\
\end{array}$ & $\begin{array}{c}\text { All } \\
\text { Heart } \\
(2)\end{array}$ & $\begin{array}{c}\text { All } \\
\text { Psychiatric } \\
(3)\end{array}$ \\
\hline \multicolumn{4}{|c|}{ Panel A: Overall population } \\
\hline $\mathrm{CO}(\mathrm{ppb})$ & $\begin{array}{l}0.0004 \\
(0.001)\end{array}$ & $\begin{array}{c}0.001 \\
(0.001)\end{array}$ & $\begin{array}{c}0.001 \\
(0.001)\end{array}$ \\
\hline $\mathrm{NO}_{2}(\mathrm{ppb})$ & $\begin{array}{c}-0.004 \\
(0.03)\end{array}$ & $\begin{array}{l}0.03 \\
(0.03)\end{array}$ & $\begin{array}{c}0.01 \\
(0.02)\end{array}$ \\
\hline $\mathrm{PM}_{2.5}\left(\mu \mathrm{g} / \mathrm{m}^{3}\right)$ & $\begin{array}{l}0.004 \\
(0.04)\end{array}$ & $\begin{array}{c}0.03 \\
(0.03)\end{array}$ & $\begin{array}{c}0.03 \\
(0.03)\end{array}$ \\
\hline $\mathrm{SO}_{2}(\mathrm{ppb})$ & $\begin{array}{l}-0.71 \\
(1.05)\end{array}$ & $\begin{array}{c}0.48 \\
(0.90)\end{array}$ & $\begin{array}{c}0.24 \\
(0.72)\end{array}$ \\
\hline \multicolumn{4}{|l|}{ Panel B: Black } \\
\hline $\mathrm{CO}(\mathrm{ppb})$ & $\begin{array}{l}-0.001 \\
(0.003)\end{array}$ & $\begin{array}{c}0.002 \\
(0.002)\end{array}$ & $\begin{array}{l}0.0001 \\
(0.002)\end{array}$ \\
\hline $\mathrm{NO}_{2}(\mathrm{ppb})$ & $\begin{array}{l}-0.06 \\
(0.07)\end{array}$ & $\begin{array}{c}0.04 \\
(0.05)\end{array}$ & $\begin{array}{c}0.01 \\
(0.05)\end{array}$ \\
\hline $\mathrm{PM}_{2.5}\left(\mu \mathrm{g} / \mathrm{m}^{3}\right)$ & $\begin{array}{l}-0.07 \\
(0.08)\end{array}$ & $\begin{array}{c}0.06 \\
(0.06)\end{array}$ & $\begin{array}{l}-0.003 \\
(0.06)\end{array}$ \\
\hline $\mathrm{SO}_{2}(\mathrm{ppb})$ & $\begin{array}{l}-1.93 \\
(1.80)\end{array}$ & $\begin{array}{c}1.08 \\
(1.31)\end{array}$ & $\begin{array}{c}0.06 \\
(1.31)\end{array}$ \\
\hline \multicolumn{4}{|l|}{ Panel C: White } \\
\hline $\mathrm{CO}(\mathrm{ppb})$ & $\begin{array}{l}-0.001 \\
(0.002)\end{array}$ & $\begin{array}{c}-0.0005 \\
(0.002)\end{array}$ & $\begin{array}{l}-0.001 \\
(0.002)\end{array}$ \\
\hline $\mathrm{NO}_{2}(\mathrm{ppb})$ & $\begin{array}{l}-0.04 \\
(0.05)\end{array}$ & $\begin{array}{c}-0.003 \\
(0.05)\end{array}$ & $\begin{array}{l}-0.04 \\
(0.04)\end{array}$ \\
\hline $\mathrm{PM}_{2.5}\left(\mu \mathrm{g} / \mathrm{m}^{3}\right)$ & $\begin{array}{l}-0.05 \\
(0.07)\end{array}$ & $\begin{array}{l}-0.02 \\
(0.07)\end{array}$ & $\begin{array}{l}-0.06 \\
(0.06)\end{array}$ \\
\hline $\mathrm{SO}_{2}(\mathrm{ppb})$ & $\begin{array}{l}-0.54 \\
(1.22)\end{array}$ & $\begin{array}{c}0.04 \\
(1.32)\end{array}$ & $\begin{array}{l}-1.05 \\
(1.03)\end{array}$ \\
\hline
\end{tabular}

Notes: This table presents the instrumental variable estimation of the effect of air pollution on hospitalization rates for the overall population, Blacks, and whites, where hospitalization rates are calculated only using the Ambulatory Surgery Center Data. Each entry presents an individual regression of an air pollutant on an illness category. Pollution concentrations are instrumented by fitted vessel tonnage in ports, wind direction, wind speed, and their interactions. All regressions include weather controls, such as the quadratics of maximum temperature, minimum temperature, dew point temperature, and precipitation. All regressions also include county-by-year, month, day-of-week, holiday, and zip code-port pair fixed effects. An observation is a zip code-port-day. Standard errors are clustered by zip code-port pair and day. Estimates are weighted by the zip code-specific population. Significance levels are indicated by ${ }^{* * *} 1 \%$, ${ }^{* *} \%$, and ${ }^{*} 10 \%$. 
Table A.35: LIML estimation of the effect of air pollution on hospitalizaton rates in California port areas

\begin{tabular}{|c|c|c|c|c|c|c|}
\hline & \multicolumn{6}{|c|}{ Dependent variable: hospital visits/million residents } \\
\hline & \multicolumn{3}{|c|}{ Respiratory } & \multirow{2}{*}{$\begin{array}{c}\text { Heart } \\
\text { All } \\
\text { Heart } \\
(4)\end{array}$} & \multicolumn{2}{|c|}{ Psychiatric } \\
\hline & $\begin{array}{c}\text { Asthma } \\
(1)\end{array}$ & $\begin{array}{c}\text { Upper } \\
\text { Respiratory } \\
(2)\end{array}$ & $\begin{array}{c}\text { All } \\
\text { Respiratory } \\
\text { (3) }\end{array}$ & & $\begin{array}{c}\text { Anxiety } \\
(5)\end{array}$ & $\begin{array}{c}\text { All } \\
\text { Psychiatric } \\
(6)\end{array}$ \\
\hline \multicolumn{7}{|l|}{ Panel A: CO } \\
\hline $\mathrm{CO}(\mathrm{ppb})$ & $\begin{array}{l}0.01^{* * *} \\
(0.002)\end{array}$ & $\begin{array}{l}0.01^{* * *} \\
(0.003)\end{array}$ & $\begin{array}{l}0.04^{* * *} \\
(0.01)\end{array}$ & $\begin{array}{l}0.01^{* * *} \\
(0.003)\end{array}$ & $\begin{array}{c}0.003^{*} \\
(0.001)\end{array}$ & $\begin{array}{c}0.01^{* *} \\
(0.003)\end{array}$ \\
\hline $\begin{array}{l}\text { Adjusted } \mathrm{R}^{2} \\
\text { Observations }\end{array}$ & $\begin{array}{c}0.33 \\
1,782,266\end{array}$ & $\begin{array}{c}0.29 \\
1,782,266\end{array}$ & $\begin{array}{c}0.42 \\
1,782,266\end{array}$ & $\begin{array}{c}0.31 \\
1,782,266\end{array}$ & $\begin{array}{c}0.17 \\
1,782,266\end{array}$ & $\begin{array}{c}0.36 \\
1,782,266\end{array}$ \\
\hline \multicolumn{7}{|l|}{ Panel B: $\mathrm{NO}_{2}$} \\
\hline $\mathrm{NO}_{2}(\mathrm{ppb})$ & $\begin{array}{l}0.23^{* * *} \\
(0.04)\end{array}$ & $\begin{array}{l}0.30^{* * *} \\
(0.06)\end{array}$ & $\begin{array}{l}0.88^{* * *} \\
(0.18)\end{array}$ & $\begin{array}{l}0.36^{* * *} \\
(0.07)\end{array}$ & $\begin{array}{l}0.07^{* *} \\
(0.03)\end{array}$ & $\begin{array}{l}0.23^{* * *} \\
(0.08)\end{array}$ \\
\hline $\begin{array}{l}\text { Adjusted } R^{2} \\
\text { Observations }\end{array}$ & $\begin{array}{c}0.33 \\
1,812,210\end{array}$ & $\begin{array}{c}0.28 \\
1,812,210\end{array}$ & $\begin{array}{c}0.42 \\
1,812,210\end{array}$ & $\begin{array}{c}0.31 \\
1,812,210\end{array}$ & $\begin{array}{c}0.17 \\
1,812,210\end{array}$ & $\begin{array}{c}0.36 \\
1,812,210\end{array}$ \\
\hline \multicolumn{7}{|l|}{ Panel C: $\mathbf{P M}_{2.5}$} \\
\hline $\mathrm{PM}_{2.5}\left(\mu \mathrm{g} / \mathrm{m}^{3}\right)$ & $\begin{array}{l}0.28^{* * *} \\
(0.06)\end{array}$ & $\begin{array}{l}0.38^{* * *} \\
(0.09)\end{array}$ & $\begin{array}{l}1.06^{* * *} \\
(0.25) \\
\end{array}$ & $\begin{array}{l}0.42^{* * *} \\
(0.10)\end{array}$ & $\begin{array}{l}0.08^{*} \\
(0.04) \\
\end{array}$ & $\begin{array}{l}0.26^{* *} \\
(0.11)\end{array}$ \\
\hline $\begin{array}{l}\text { Adjusted } R^{2} \\
\text { Observations }\end{array}$ & $\begin{array}{c}0.33 \\
1,720,810\end{array}$ & $\begin{array}{c}0.29 \\
1,720,810\end{array}$ & $\begin{array}{c}0.42 \\
1,720,810\end{array}$ & $\begin{array}{c}0.31 \\
1,720,810\end{array}$ & $\begin{array}{c}0.18 \\
1,720,810\end{array}$ & $\begin{array}{c}0.36 \\
1,720,810\end{array}$ \\
\hline \multicolumn{7}{|l|}{ Panel D: $\mathrm{SO}_{2}$} \\
\hline $\mathrm{SO}_{2}(\mathrm{ppb})$ & $\begin{array}{l}5.52^{* * *} \\
(1.30)\end{array}$ & $\begin{array}{l}8.20^{* * * *} \\
(1.85)\end{array}$ & $\begin{array}{c}22.39^{* * *} \\
(4.99)\end{array}$ & $\begin{array}{l}9.28^{* * *} \\
(2.05) \\
\end{array}$ & $\begin{array}{l}2.28^{* *} \\
(0.91) \\
\end{array}$ & $\begin{array}{l}6.55^{* * *} \\
(2.18) \\
\end{array}$ \\
\hline $\begin{array}{l}\text { Adjusted } \mathrm{R}^{2} \\
\text { Observations }\end{array}$ & $\begin{array}{c}0.33 \\
1,749,073\end{array}$ & $\begin{array}{c}0.28 \\
1,749,073\end{array}$ & $\begin{array}{c}0.42 \\
1,749,073\end{array}$ & $\begin{array}{c}0.31 \\
1,749,073\end{array}$ & $\begin{array}{c}0.17 \\
1,749,073\end{array}$ & $\begin{array}{c}0.36 \\
1,749,073\end{array}$ \\
\hline
\end{tabular}

Notes: This table presents the LIML instrumental variable estimation of the effect of air pollution on hospitalization rates. Each entry presents an individual regression of an air pollutant on an illness category. Pollution concentrations are instrumented by fitted vessel tonnage in ports, wind direction, wind speed, and their interactions. All regressions include weather controls, such as the quadratics of maximum temperature, minimum temperature, dew point temperature, and precipitation. All regressions also include county-by-year, month, day-of-week, holiday, and zip code-port pair fixed effects. An observation is a zip code-port-day. Standard errors are clustered by zip code-port pair and day. Estimates are unweighted. Significance levels are indicated by $* * * 1 \%$, ${ }^{* *} 5 \%$, and $* 10 \%$. 
Table A.36: Placebo tests for the effect of California Ocean-Going Vessel At-Berth Regulation on air pollution

\begin{tabular}{|c|c|c|c|c|}
\hline & \multicolumn{4}{|c|}{ Dependent variable: residual of log pollution concentration } \\
\hline & $\begin{array}{l}\mathrm{CO} \\
(1) \\
\end{array}$ & $\begin{array}{c}\mathrm{NO}_{2} \\
(2)\end{array}$ & $\begin{array}{c}\mathrm{PM}_{2.5} \\
(3)\end{array}$ & $\begin{array}{c}\mathrm{SO}_{2} \\
(4)\end{array}$ \\
\hline \multicolumn{5}{|c|}{ Panel A: One year before the policy } \\
\hline CA Regulation & $\begin{array}{c}0.06 \\
(0.08)\end{array}$ & $\begin{array}{c}0.05 \\
(0.08)\end{array}$ & $\begin{array}{c}0.04 \\
(0.11)\end{array}$ & $\begin{array}{c}0.04 \\
(0.13)\end{array}$ \\
\hline Date & $\begin{array}{l}-0.001 \\
(0.001)\end{array}$ & $\begin{array}{l}-0.002 \\
(0.002)\end{array}$ & $\begin{array}{c}0.001 \\
(0.002)\end{array}$ & $\begin{array}{l}-0.002 \\
(0.002)\end{array}$ \\
\hline CA Regulation $\times$ Date & $\begin{array}{c}0.003 \\
(0.002)\end{array}$ & $\begin{array}{c}0.003 \\
(0.002)\end{array}$ & $\begin{array}{c}-0.01^{* * *} \\
(0.003)\end{array}$ & $\begin{array}{c}0.01^{*} \\
(0.003)\end{array}$ \\
\hline Pre-policy Mean & 630.35 & 18.70 & 14.84 & 1.89 \\
\hline Observations & 4,809 & 5,303 & 2,076 & 3,290 \\
\hline \multicolumn{5}{|c|}{ Panel B: One year after the policy } \\
\hline CA Regulation & $\begin{array}{c}0.13 \\
(0.10)\end{array}$ & $\begin{array}{c}0.08 \\
(0.08)\end{array}$ & $\begin{array}{c}0.07 \\
(0.10)\end{array}$ & $\begin{array}{c}0.07 \\
(0.25)\end{array}$ \\
\hline Date & $\begin{array}{l}-0.002 \\
(0.001)\end{array}$ & $\begin{array}{c}-0.0003 \\
(0.001)\end{array}$ & $\begin{array}{c}0.002 \\
(0.002)\end{array}$ & $\begin{array}{c}0.003 \\
(0.004)\end{array}$ \\
\hline CA Regulation $\times$ Date & $\begin{array}{c}0.001 \\
(0.002)\end{array}$ & $\begin{array}{l}0.0004 \\
(0.003) \\
\end{array}$ & $\begin{array}{l}-0.01^{* *} \\
(0.002)\end{array}$ & $\begin{array}{c}-0.003 \\
(0.01) \\
\end{array}$ \\
\hline Pre-policy Mean & 586.64 & 17.96 & 13.89 & 1.74 \\
\hline Observations & 4,861 & 5,368 & 2,890 & 3,550 \\
\hline \multicolumn{5}{|c|}{ Panel C: Neighboring areas } \\
\hline CA Regulation & $\begin{array}{c}0.43 \\
(0.26)\end{array}$ & $\begin{array}{l}0.13^{*} \\
(0.07)\end{array}$ & $\begin{array}{c}-0.18^{*} \\
(0.10)\end{array}$ & $\begin{array}{l}-0.01 \\
(0.20)\end{array}$ \\
\hline Date & $\begin{array}{c}-0.0002 \\
(0.004)\end{array}$ & $\begin{array}{l}-0.001 \\
(0.001)\end{array}$ & $\begin{array}{c}0.003 \\
(0.002)\end{array}$ & $\begin{array}{c}0.01 \\
(0.01)\end{array}$ \\
\hline CA Regulation $\times$ Date & $\begin{array}{l}-0.01 \\
(0.01)\end{array}$ & $\begin{array}{c}-0.0001 \\
(0.002) \\
\end{array}$ & $\begin{array}{l}-0.01^{*} \\
(0.004)\end{array}$ & $\begin{array}{c}-0.003 \\
(0.02)\end{array}$ \\
\hline Pre-policy Mean & 394.78 & 10.81 & 12.43 & 1.17 \\
\hline Observations & 1,190 & 2,500 & 1,074 & 538 \\
\hline
\end{tabular}

Notes: This table presents the placebo tests for RDD estimation of the effect of the California at-berth regulation on local air pollution. The second-stage RDD dependent variable is taken from the residuals by regressing $\log$ pollution concentrations on weather controls (i.e., the quadratics of maximum temperature, minimum temperature, dew point temperature, precipitation, wind speed, and relative wind direction between a monitorport pair), fixed effects (i.e., county-by-year, month, day-of-week, holiday, and port-monitor pair), and log vessel tonnage (instrumented by seven-day lagged and 500-mile distant cyclones from ports). The local linear bandwidth is specified as 65 days on both sides of the policy threshold. Panel A shows the results of specifying placebo policy dates one year before the actual policy date. Panel B shows the results of specifying placebo policy dates one year after the actual policy date. Panel $\mathrm{C}$ shows the results by assigning the policy date to neighboring areas located 75 to 100 miles from ports. An observation is a monitor-port-day. Standard errors are clustered by monitor-port pair and normalized day. Significance levels are indicated by ${ }^{* * *} 1 \%,{ }^{* *} 5 \%$, and ${ }^{*} 10 \%$. 
Table A.37: Projected energy consumption by marine vessels in the United States

\begin{tabular}{lcccc}
\hline \hline & \multicolumn{2}{c}{ Fossil Fuel } & \multicolumn{2}{c}{ Electricity } \\
\cline { 2 - 3 } \cline { 5 - 5 } & Reference & Shore Power & & Reference \\
\hline 2017 & 0.78 & 0.78 & 0.00 & Shore Power \\
2020 & 0.77 & 0.72 & 0.01 & 0.00 \\
2025 & 0.81 & 0.64 & 0.01 & 0.05 \\
2030 & 0.85 & 0.66 & 0.01 & 0.18 \\
2035 & 0.90 & 0.70 & 0.01 & 0.19 \\
2040 & 0.93 & 0.72 & 0.01 & 0.22 \\
2045 & 0.97 & 0.74 & 0.01 & 0.22 \\
2050 & 1.01 & 0.77 & 0.01 & 0.24 \\
\hline \hline
\end{tabular}

Notes: This table presents projected marine vessel energy consumption simulated in Yale-NEMS. The unit is quadrillion Btu. The data include electricity and fossil fuel consumption for the reference case and the shore power scenario. 


\section{B Supplementary Figures (For Online Publication)}

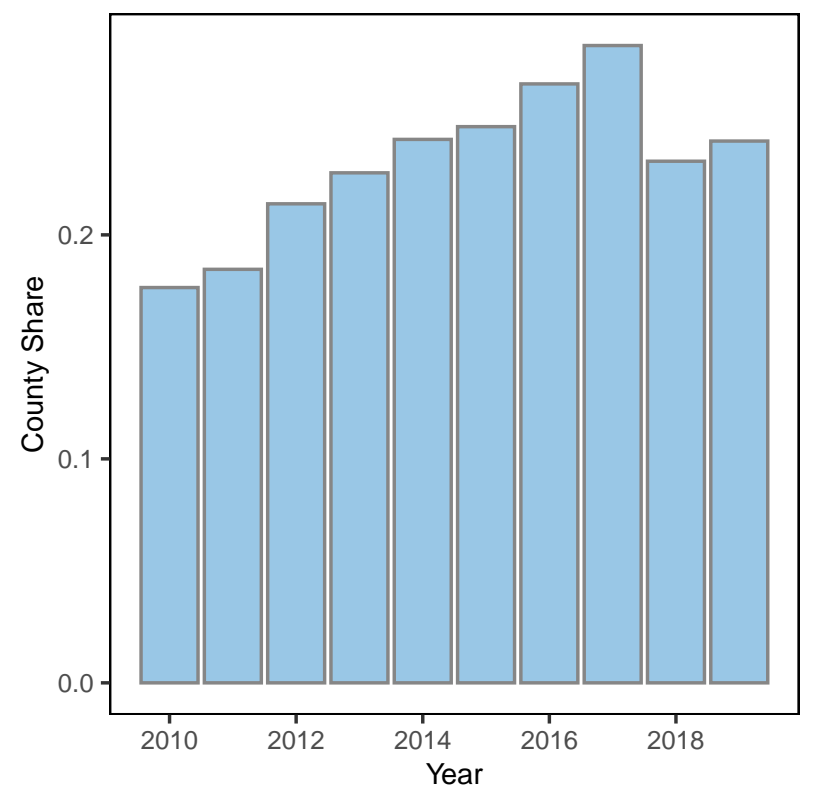

Figure B.1: Share of nonattainment counties adjacent to the major ports in the United States.

Notes: The figure plots the share of nonattainment counties that fail to meet the National Ambient Air Quality Standards and locate within a 50-mile radius of the major ports in the United States. The standards include Carbon Monoxide (1971), Nitrogen Dioxide (1971), 8-Hour Ozone (2008, 2015), $\mathrm{PM}_{10}$ (1987), $\mathrm{PM}_{2.5}$ $(1997,2006,2012)$, Sulfur Dioxide $(1971,2010)$. The data are obtained from U.S. EPA NAAQS Greenbook. 


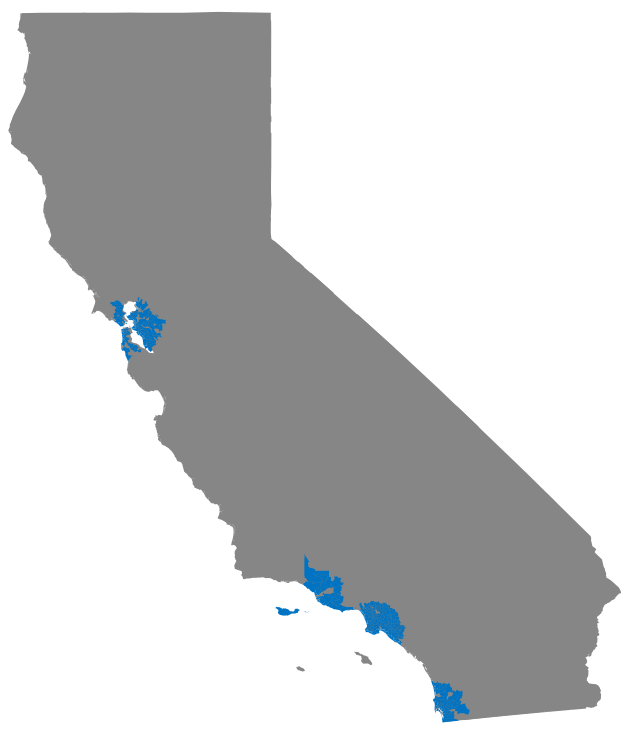

Figure B.2: Locations of zip codes near the major California ports.

Notes: This figure plots the locations of zip codes that are within 25 miles of the major ports in California, shown in blue areas. According to the U.S. 2010 Decennial Census, around 47 percent of the population in California resides in the blue areas.
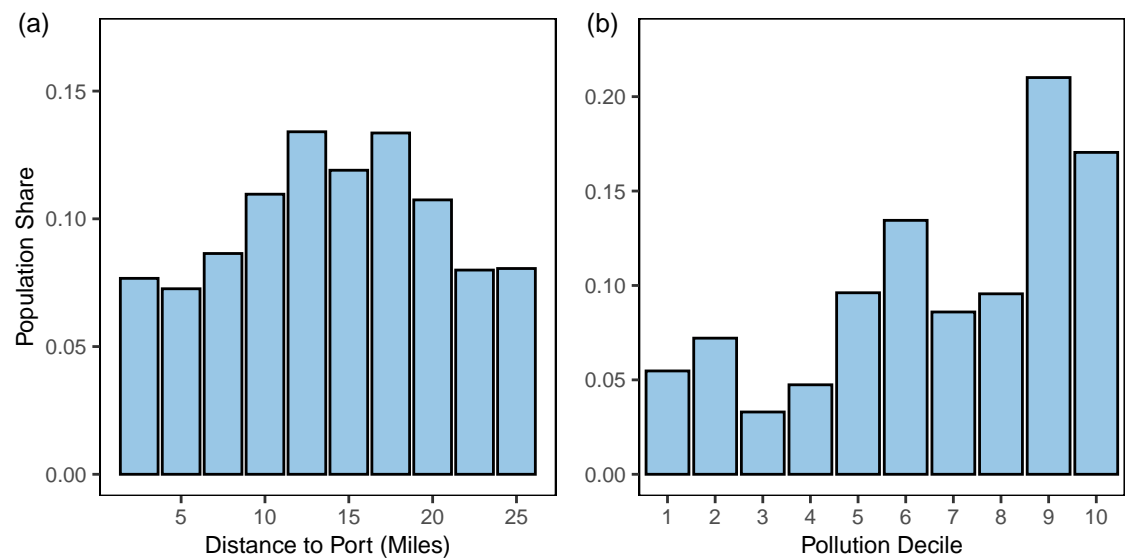

Figure B.3: (a) Distribution of Hispanic population by distance to major California ports. (b) Distribution of the Hispanic population in California port areas by decile of $\mathrm{PM}_{2.5}$ concentration.

Notes: Panel (a) plots population distribution in the California port areas by the distance between census tract and port for the Hispanic population. We obtain the population data at the census tract level and assign a distance between a census tract to its nearest mapped port to the population within the census tract. Panel (b) plots population distribution in the California port areas by decile of $\mathrm{PM}_{2.5}$ concentration. Larger pollution deciles represent higher pollution exposures. The data are obtained from the U.S. 2010 Decennial Census and U.S. EPA Air Quality System. 

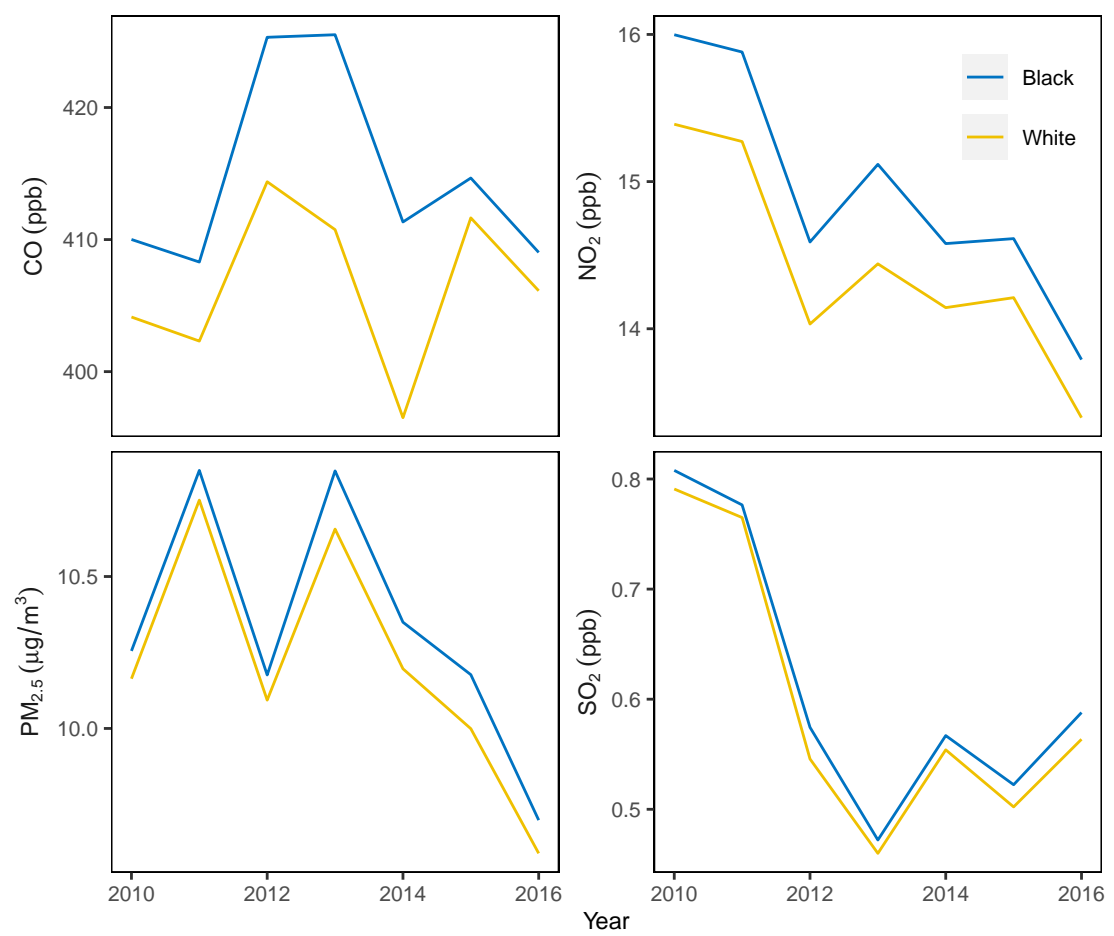

Figure B.4: Annual air pollution exposure for individuals visiting hospitals by race.

Notes: This figure plots the annual averages of baseline pollution exposure separately for non-Hispanic Black and white patients in the areas within 25 miles from ports in California. The patients visit hospitals due to psychiatric, respiratory, and heart-related illnesses during 2010-2016. The pollution data are obtained from the U.S. EPA Air Quality System, and the hospital visit data are obtained Office of Statewide Health Planning and Development of California. 


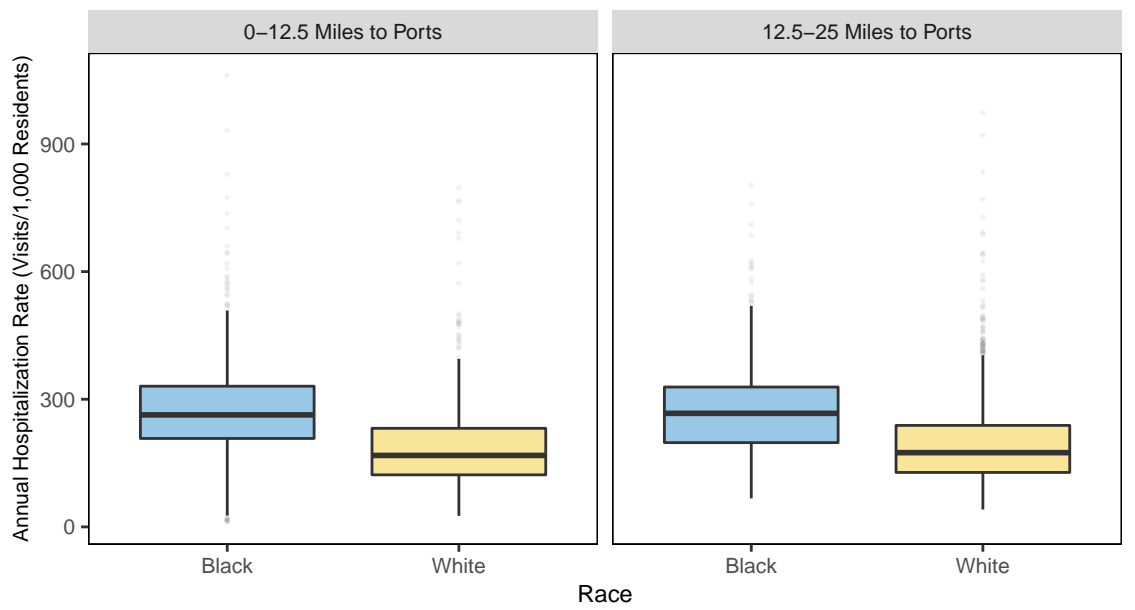

Figure B.5: Boxplots of annual hospitalizations rates in California port areas.

Notes: This figure presents the boxplots of annual hospitalization rates, separately for non-Hispanic Black and white population in the areas within 0-12.5 miles from ports and 12.5-25 miles from ports in California. The hospitalization rate is calculated as the annual total hospital visits related to psychiatric, respiratory, and heart-related illnesses in each zip code for 2010-2016. The grey dots represent outliers. The dashed lines represent sample means. The gap between the dashed lines in the left panel is 87, while the gap in the right panel is 81 . The data are obtained from the Office of Statewide Health Planning and Development of California. We exclude the zip codes having less than 1,000 race-specific populations in our analysis. We also do not plot the observations with annual hospitalization rates greater than 1,000 .

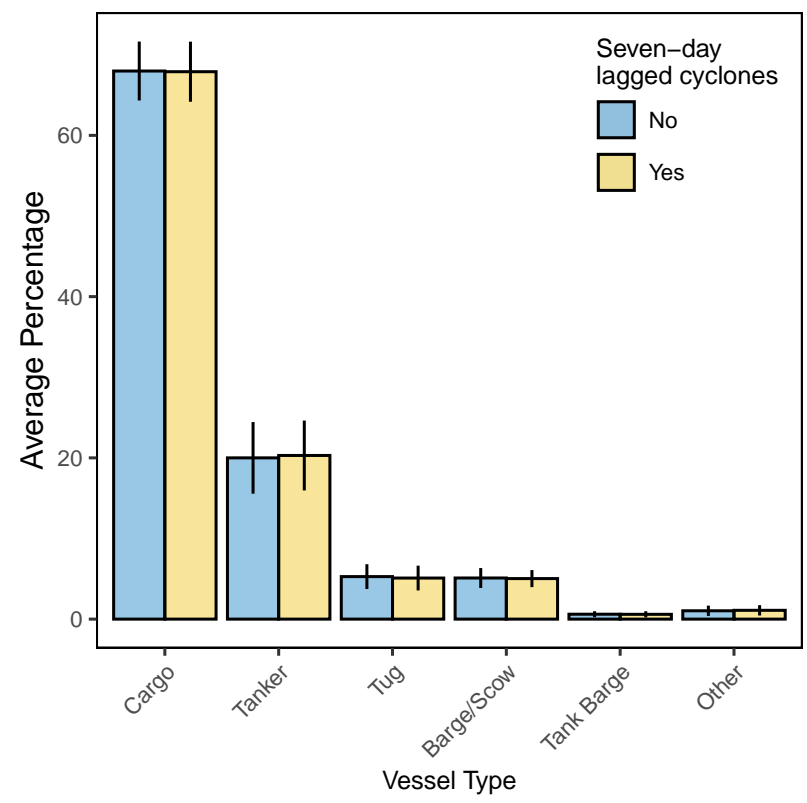

Figure B.6: Average daily share of vessel type in ports.

Notes: This figure presents the average daily share of vessel types in major 27 U.S. ports, separately for the days when there exist seven-day lagged and 500-mile distant tropical cyclones in the ocean and the days when there are no such cyclones. The error bars indicate standard deviations. The data are obtained from the U.S. Army Corps of Engineers. 

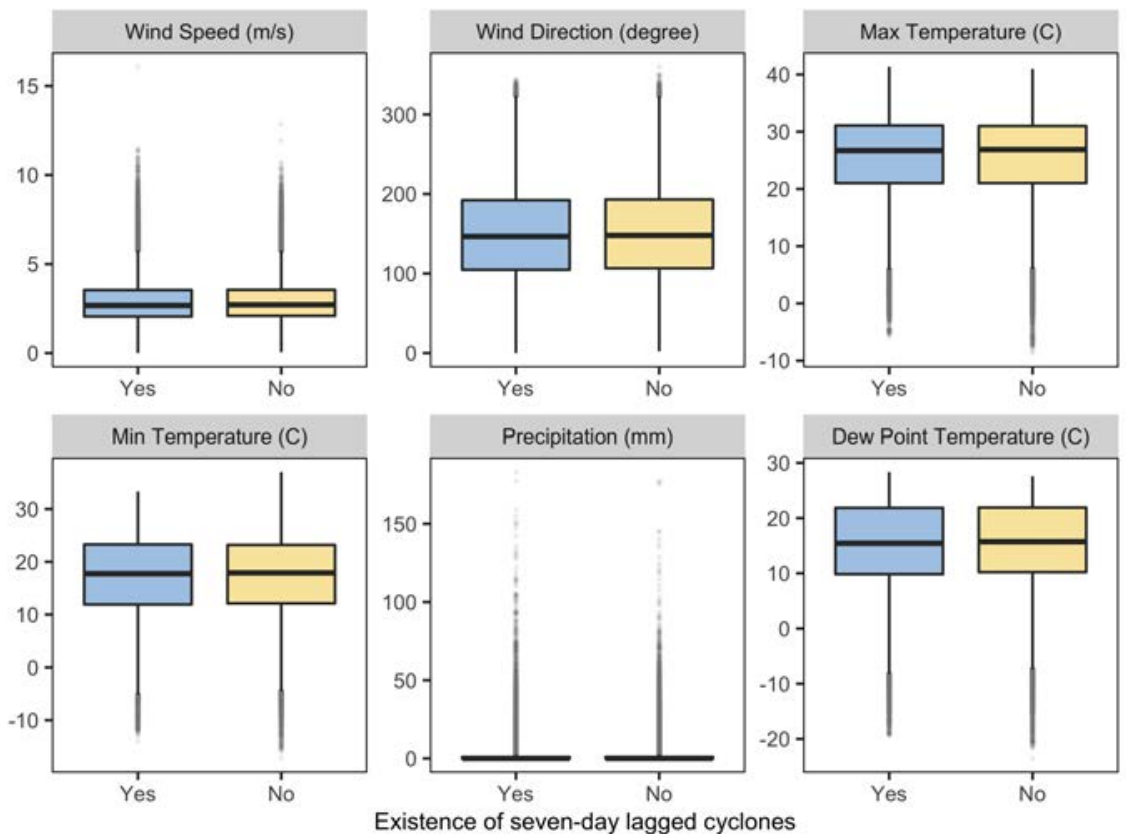

Figure B.7: Boxplots of local weather in port areas.

Notes: This figure presents the boxplots of weather variables in the U.S. port areas, separately for the month-days when there exist seven-day lagged and 500-mile distant tropical cyclones in the ocean and the same month-days when there are no such cyclones. The grey dots represent outliers. The data are obtained from the NOAA Integrated Surface Database. 


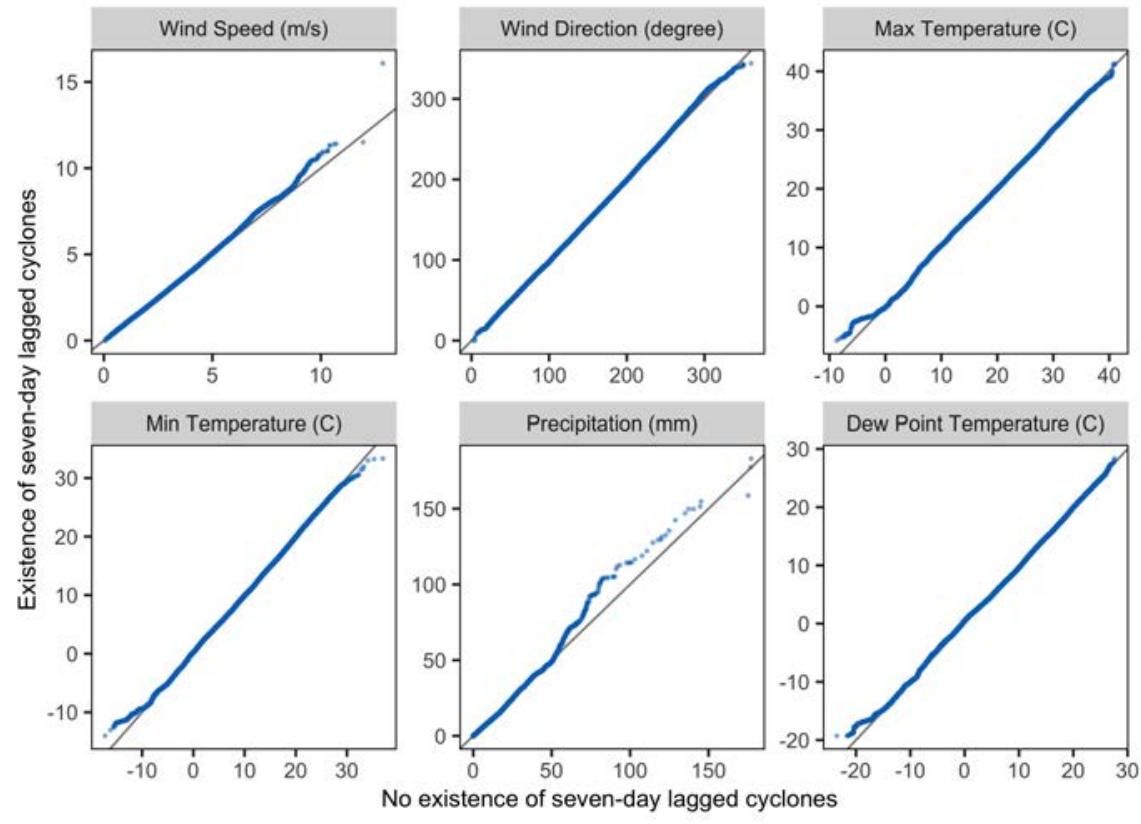

Figure B.8: Empirical quantile-quantile plots of local weather in port areas.

Notes: This figure presents the QQ plots of weather variables in the U.S. port areas. The panels compare two data samples: one for the month-days when there exist seven-day lagged and 500-mile distant tropical cyclones in the ocean and the other for the same month-days when there are no such cyclones. The data are obtained from the NOAA Integrated Surface Database. 

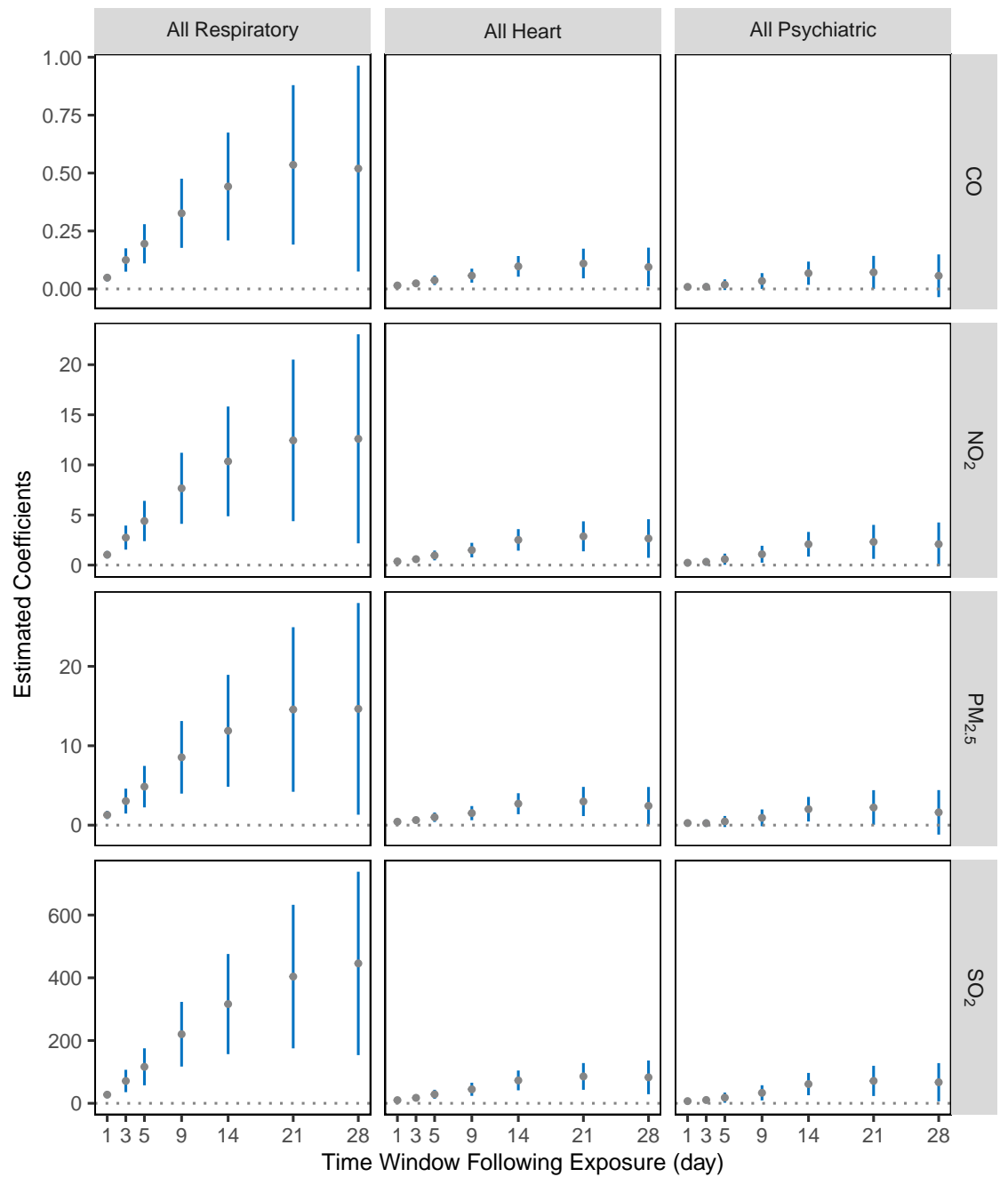

Figure B.9: Effect of air pollution on hospitalization rate for the overall population with different time windows following pollution exposure in California port areas.

Notes: This figure plots IV estimates of equation (3) with different time windows following pollution exposure. Estimates are shown for time windows of one day, three days, five days, nine days, 14 days, 21 days, and 28 days. The dependent variable is the sum of hospital visits over the number of time windows per million residents, indicated on the x-axis. The one-day window estimates are also reported in columns (3), (4), and (7) in Panel A of Table 2. The pollution measures are instrumented by fitted vessel tonnage in ports, wind direction, wind speed, and interactions. All regressions include a set of weather controls, such as the quadratics of maximum, minimum, and dew point temperatures, precipitation, and their leads up to the time window. All regressions also include county-by-year, month, day-of-week, holiday, and zip code-port pair fixed effects. An observation is a zip code-port-day. Standard errors are clustered by zip code-port pair and day. Estimates are weighted by zip code-specific population. The error bars represent $95 \%$ confidence intervals. 


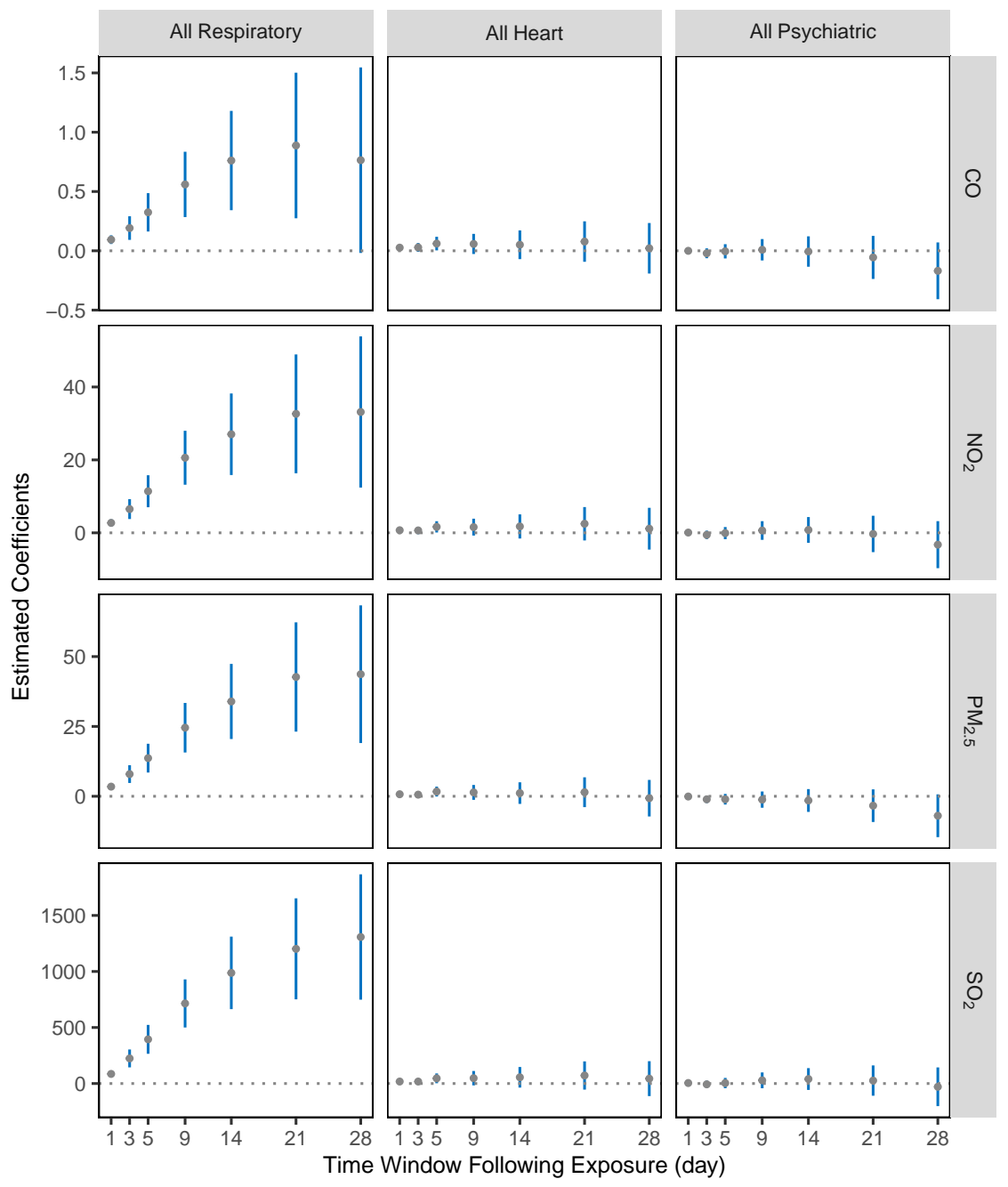

Figure B.10: Effect of air pollution on hospitalization rate for Blacks with different time windows following pollution exposure in California port areas.

Notes: This figure plots IV estimates of equation (3) with different time windows following pollution exposure. Estimates are shown for time windows of one day, three days, five days, nine days, 14 days, 21 days, and 28 days. The dependent variable is the sum of hospital visits over the number of time windows per million residents, indicated on the x-axis. The one-day window estimates are also reported in columns (3), (4), and (7) in Panel B of Table 2. The pollution measures are instrumented by fitted vessel tonnage in ports, wind direction, wind speed, and interactions. All regressions include a set of weather controls, such as the quadratics of maximum, minimum, and dew point temperatures, precipitation, and their leads up to the time window. All regressions also include county-by-year, month, day-of-week, holiday, and zip code-port pair fixed effects. An observation is a zip code-port-day. Standard errors are clustered by zip code-port pair and day. Estimates are weighted by zip code-specific population. The error bars represent $95 \%$ confidence intervals. 

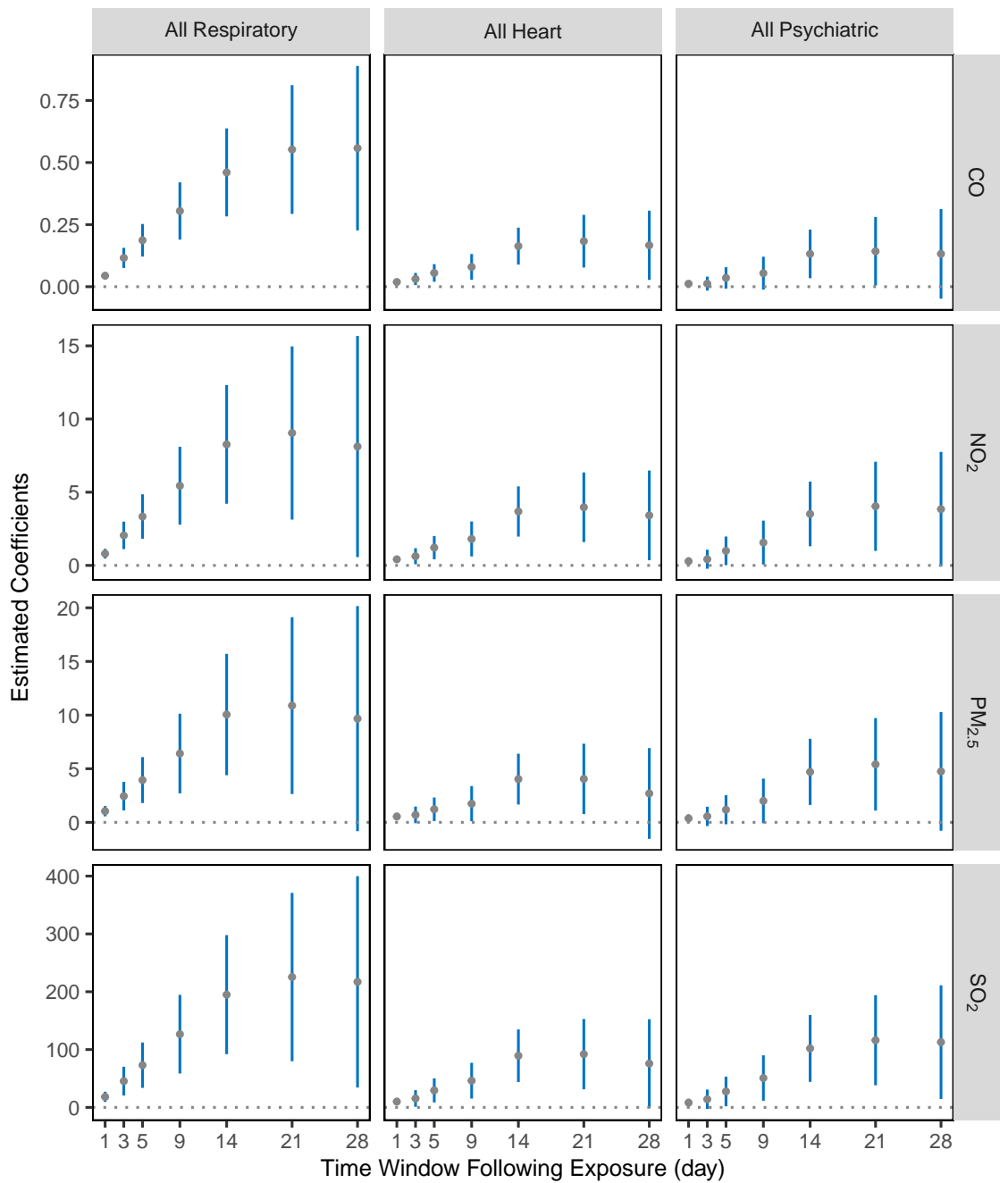

Figure B.11: Effect of air pollution on hospitalization rate for whites with different time windows following pollution exposure in California port areas.

Notes: This figure plots IV estimates of equation (3) with different time windows following pollution exposure. Estimates are shown for time windows of one day, three days, five days, nine days, 14 days, 21 days, and 28 days. The dependent variable is the sum of hospital visits over the number of time windows per million residents, indicated on the x-axis. The one-day window estimates are also reported in columns (3), (4), and (7) in Panel C of Table 2. The pollution measures are instrumented by fitted vessel tonnage in ports, wind direction, wind speed, and interactions. All regressions include a set of weather controls, such as the quadratics of maximum, minimum, and dew point temperatures, precipitation, and their leads up to the time window. All regressions also include county-by-year, month, day-of-week, holiday, and zip code-port pair fixed effects. An observation is a zip code-port-day. Standard errors are clustered by zip code-port pair and day. Estimates are weighted by zip code-specific population. The error bars represent $95 \%$ confidence intervals. 


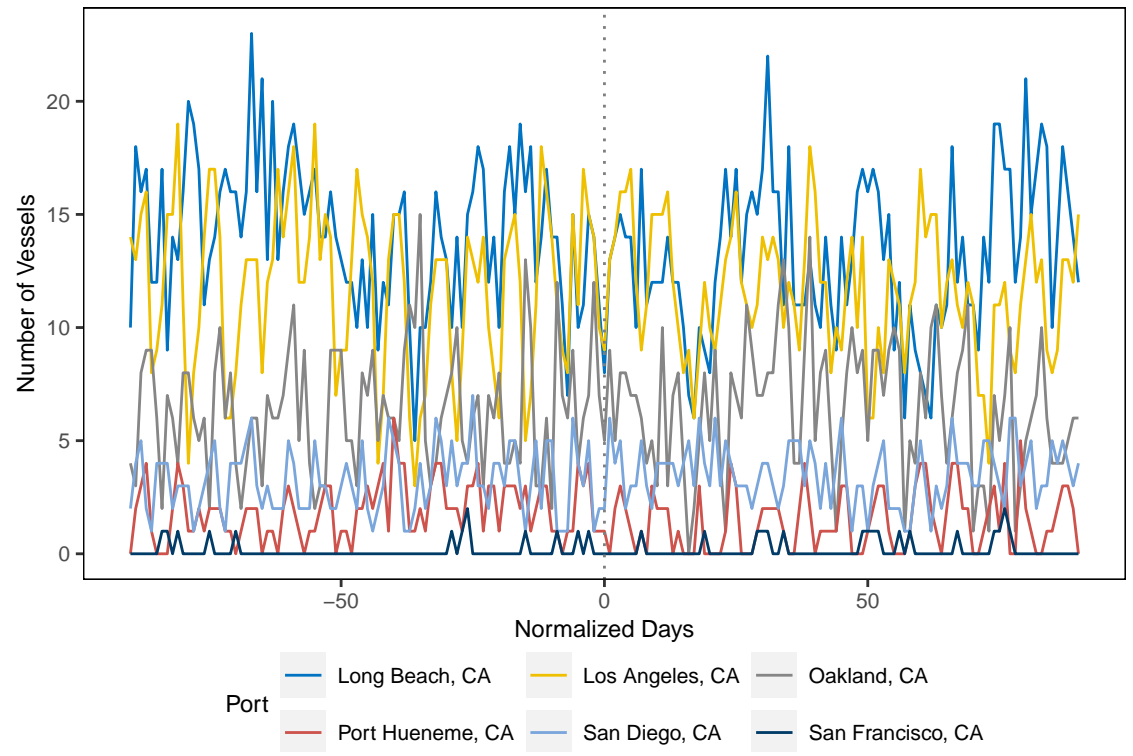

Figure B.12: Vessel counts in ports before and after the Californian at-berth regulation.

Notes: This figure plots the number of vessels in ports before and after the first phase of the Californian at-berth regulation (i.e., January 1, 2010).

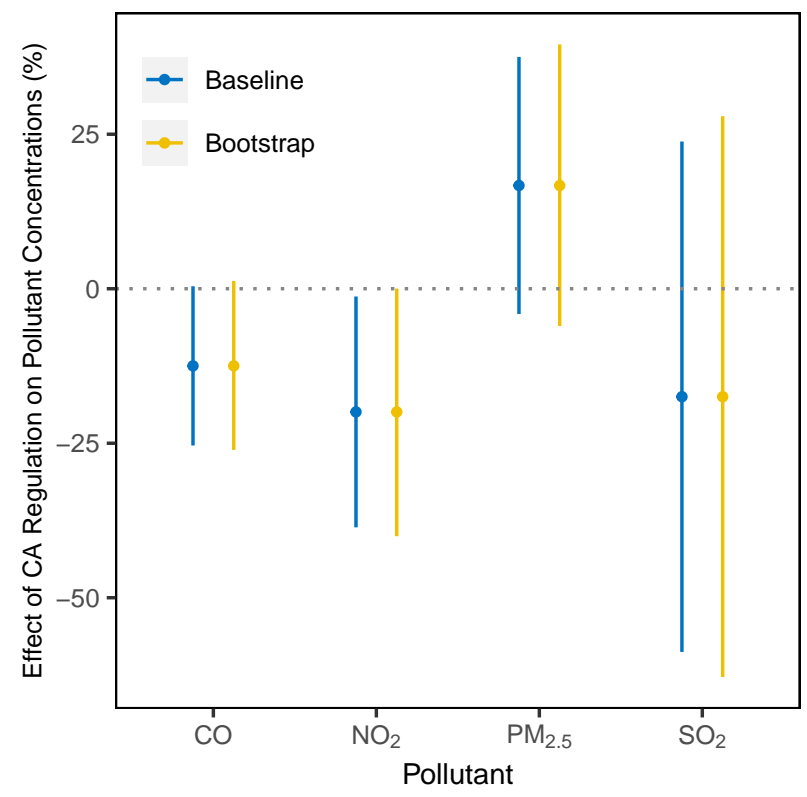

Figure B.13: Cluster bootstrap inference for the effect of California Ocean-Going Vessel At-Berth Regulation on air pollutant concentrations.

Notes: The figure plots the the local linear RDD point estimates and 95\% confidence intervals from the baseline regression (shown in Table 5) and a wild cluster bootstrap algorithm. 


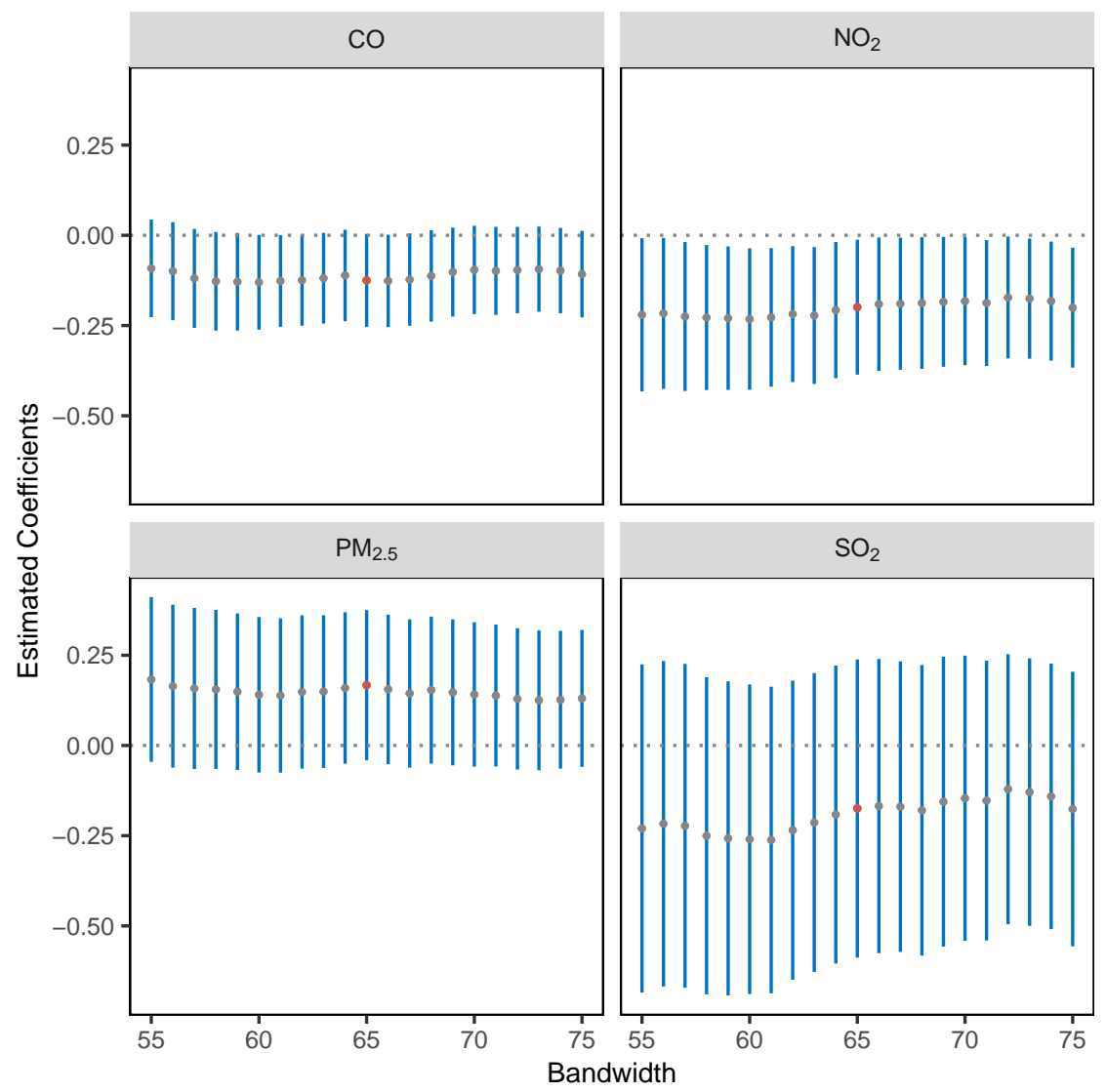

Figure B.14: Robustness check for the effect of California Ocean-Going Vessel At-Berth Regulation on air pollutant concentrations with varying RDD bandwidths.

Notes: The figure plots the local linear RDD point estimates and 95\% confidence intervals with varying bandwidths (i.e., 55-75 days on both sides of the policy threshold). The baseline bandwidth is 65 days, as indicated by the red dots. 


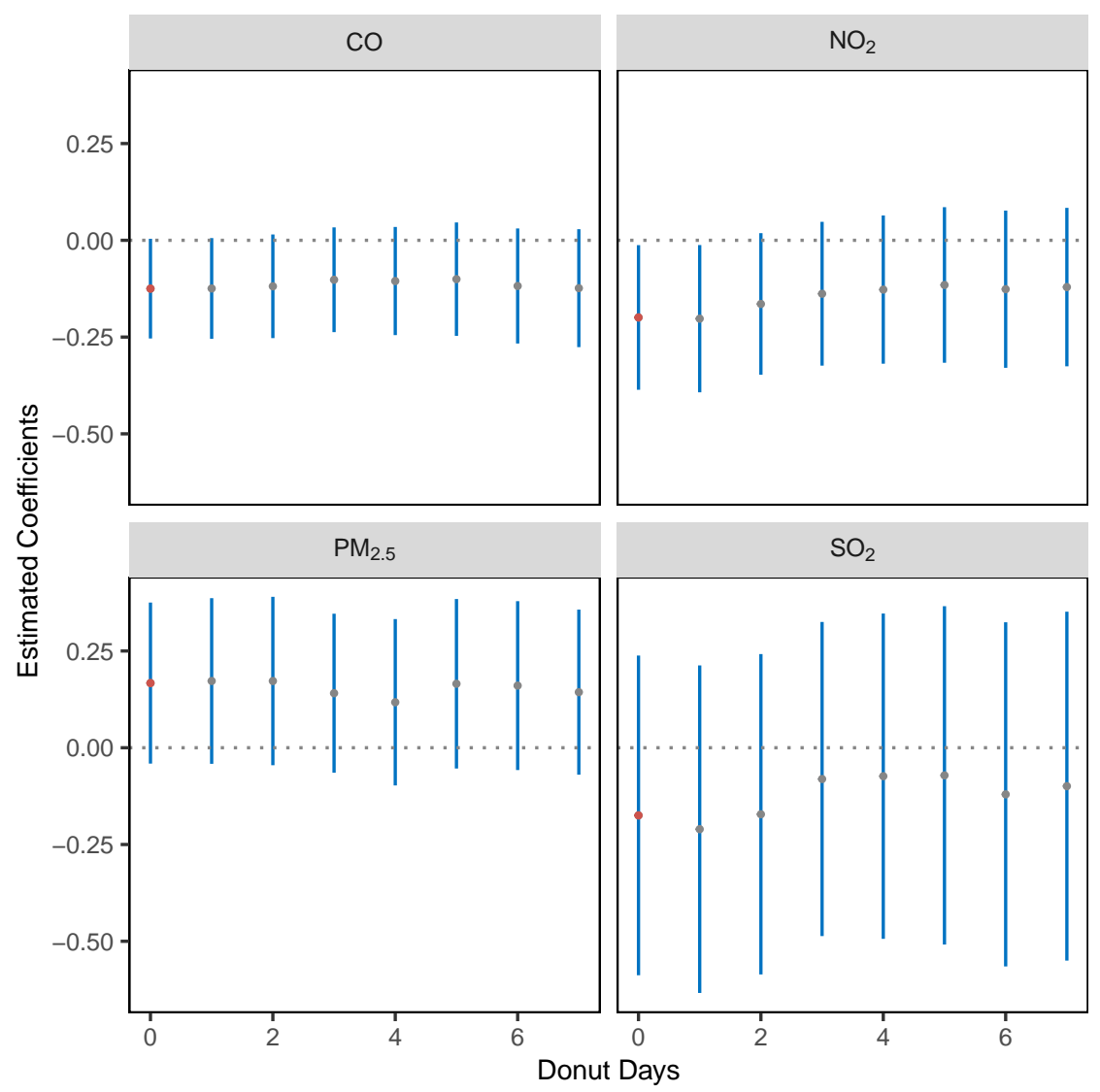

Figure B.15: Robustness check for the effect of California Ocean-Going Vessel At-Berth Regulation on air pollutant concentrations with varying RDD "donut" periods.

Notes: The figure plots the local linear RDD point estimates and 95\% confidence intervals with varying "donut" periods (i.e., removing 0-7 days of observations on both sides of the policy threshold). The baseline "donut" period is 0 day, as indicated by the red dots. 


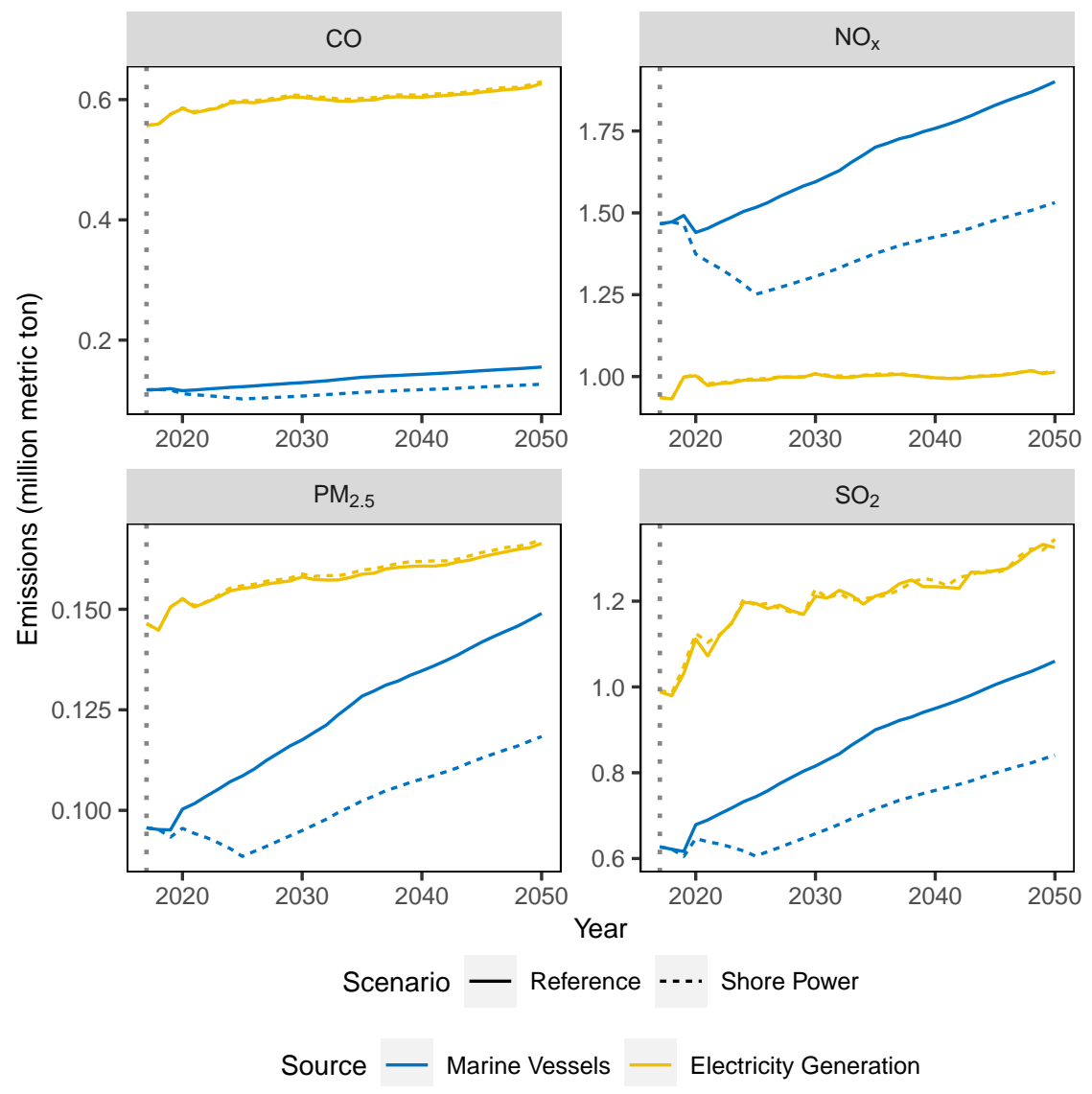

Figure B.16: Projected emissions of local air pollutants from marine vessels and electricity generation in the United States.

Notes: This figure plots local air pollutant emissions from marine vessels and power plants in the United States under the reference and shore power scenarios, projected in Yale-NEMS. The projection starts from 2017 indicated by the gray dotted lines. 


\section{Supplementary Analysis (For Online Publication)}

\section{C.1 Results Comparison}

This appendix presents supplementary analyses for the main text. We first present comparisons of our baseline estimates to the existing evidence in the literature. We then show the estimates of the reduced-form relationship between vessels in ports and human health.

Effect of vessels in ports on air pollution. We first compare our estimates in Table 1 to the existing evidence on the contributions of seaports to local air pollution. We are not aware of any other study that explores this question in the literature; however, some government reports and online articles address the relationship between port and local air pollution. For example, U.S. EPA estimates that ocean-going vessels contribute to $7 \%$ of $\mathrm{NO}_{\mathrm{x}}$ emissions in Ports of Baton Rouge/New Orleans and up to $61 \%$ in the Santa Barbara areas (EPA, 2003). In addition, another evidence states that marine shipping in ports accounts for as much as half $\mathrm{SO}_{\mathrm{x}}$ emissions in major port cities, such as Los Angeles. ${ }^{1}$

Our estimates in Table 1 show that one percent increase in vessel tonnage in a port per day leads to $0.3-0.4 \%$ increases in pollution concentrations for $\mathrm{NO}_{2}$ and $\mathrm{SO}_{2}$. This suggests that marine shipping in ports contributes to $40 \%$ of local air pollution in port areas in the United States, within the range of previously cited sources.

We also compare our estimates to the NAAQS to examine whether pollution from ports is likely to lead to nonattainment status. ${ }^{2}$ The current one-hour standard for $\mathrm{CO}$ is that the pollution concentration cannot exceed 35,000 ppb more than once per year. Our results show that one average-sized vessel in a port (a 7.6\% increase of vessel tonnage in the U.S.) results in a $13.7 \mathrm{ppb}$ increase in $\mathrm{CO}$ pollution. ${ }^{3}$ Combining this increase with the average daily maximum of $\mathrm{CO}$, the estimated resulting concentration is $822 \mathrm{ppb}(13.7+808.2)$, which is far below the EPA standard. Similarly, the resulting pollution concentrations for $\mathrm{NO}_{2}$ and $\mathrm{SO}_{2}$ due to average gross vessel tonnage in ports are also below the EPA's one-hour standards. ${ }^{4}$

EPA has established a 24-hour standard for $\mathrm{PM}_{2.5}$ at 35 micrograms per cubic meter $\left(\mu \mathrm{g} / \mathrm{m}^{3}\right)$. Adding the increase in $\mathrm{PM}_{2.5}$ concentrations $0.35 \mu \mathrm{g} / \mathrm{m}^{3}(7.6 \times 0.43 / 100 \times 10.67)$ (owing to an average-sized vessel in a port) to the daily 24-hour average $\left(10.67 \mu \mathrm{g} / \mathrm{m}^{3}\right)$

\footnotetext{
${ }^{1}$ See https://www.ft.com/content/31d0e224-dde8-11e8-9f04-38d397e6661c.

${ }^{2}$ The details of the standards for pollutants considered harmful to public health and the environment are available at https: / / www.epa.gov/ criteria-air-pollutants/naaqs-table.

${ }^{3}$ The $13.7 \mathrm{ppb}$ increase is calculated from $7.6 \times 0.37 / 100 \times 485.97$ based on the estimates in Table 1 and summary statistics reported in Table A.3.

${ }^{4}$ The one-hour standards for $\mathrm{NO}_{2}$ and $\mathrm{SO}_{2}$ are 100 parts per billion (ppb) and $75 \mathrm{ppb}$, respectively.
} 
results in a concentration of $11 \mu \mathrm{g} / \mathrm{m}^{3}$, which is around $31 \%$ of the EPA standard. Note that the calculations presented above are based on the summary averages across all ports. Some areas on certain days may still exceed the EPA standards due to increased vessel counts in ports.

Effect of air pollution on health. Since there is a large body of economics and epidemiological literature examining the effect of air pollution on health, it is natural to compare our estimates in Panel A of Table 2 to the literature. Compared to Schlenker and Walker (2016), our estimates associated with the effect of $\mathrm{CO}$ on respiratory and heart hospital visits are relatively larger. For example, we find that a one ppb increase in CO concentration leads to a $0.02 \%$ increase in all respiratory hospital visits, while Schlenker and Walker (2016) find a $0.037 \%$ increase. The discrepancy in results may be driven by different studied locations. Other epidemiological studies show the effect of a one $\mathrm{ppb}$ increase in $\mathrm{CO}$ pollution on respiratory hospital visits in a range of $0.001-0.008 \%$ (e.g., Hwang and Chan, 2002; Peel et al., 2005; Stieb et al., 2009), which are smaller than our estimates.

For heart-related illness, we find that a one $\mu \mathrm{g} / \mathrm{m}^{3}$ increase in $\mathrm{PM}_{2.5}$ concentration leads to a $0.31 \%$ increase of hospital visits, which is higher than the estimates $0.13-0.15 \%$ in the epidemiology literature (e.g., Dominici et al., 2006; Bell et al., 2008). Two recent epidemiology studies find evidence that a $0.11 \%$ increase in psychiatric hospital visits is attributed to a one $\mu \mathrm{g} / \mathrm{m}^{3}$ increase in $\mathrm{PM}_{2.5}$ concentration, which is also smaller than our estimate. We find consistent larger estimates for the effect of air pollution on hospital visits because we focus on highly polluted areas, or our quasi-experimental framework corrects the attenuation bias.

\section{C.2 RIF-Quantile Effect of Air Pollution on Health}

We provide additional evidence on how pollution affects different unconditional quantiles of the hospitalization distributions for Blacks and whites using the unconditional quantile regression method introduced by Firpo et al. (2009). This method involves calculating the re-centered influence function (RIF) for the outcome variable (e.g., hospitalization rates) at a certain quantile and replace the dependent variable in equation (3) with the calculated RIF. The RIF for hospitalization $y$ at the $n$th quantile $q_{n}$ is calculated as $\operatorname{RIF}\left(y, q_{n}\right)=q_{n}+\frac{n-\mathbb{1}\left\{y \leq q_{n}\right\}}{f_{y}\left(q_{n}\right)}$, where $f_{y}\left(q_{n}\right)$ is the density function of $y$ at quantile $q_{n}$. In practice, we calculate 19 RIF statistics, starting from the 5th quantile to the 95th quantile of the hospitalization rate distribution for each subsample of Blacks and whites. In total, we fit 38 RIF-quantile regressions for each of the four studied air pollutants. Because pollution is endogenous, we adopt a control-function approach, where we include the residuals 
from the first-stage regression equation (4) into the regression equation of interest (3). One caveat of this RIF-quantile analysis using the control-function approach is that we should interpret the standard errors carefully because there may exist sampling error in the first-stage residuals.

The regression estimates illustrate how the effect of pollution on hospitalization rates directly transforms to the unconditional distribution of hospitalization rates. Figure C.1 presents the RIF-quantile regression estimates by race and pollutant, suggesting that at the upper quantiles of the hospitalization rate distribution, air pollution has larger impacts on Blacks compared to whites.

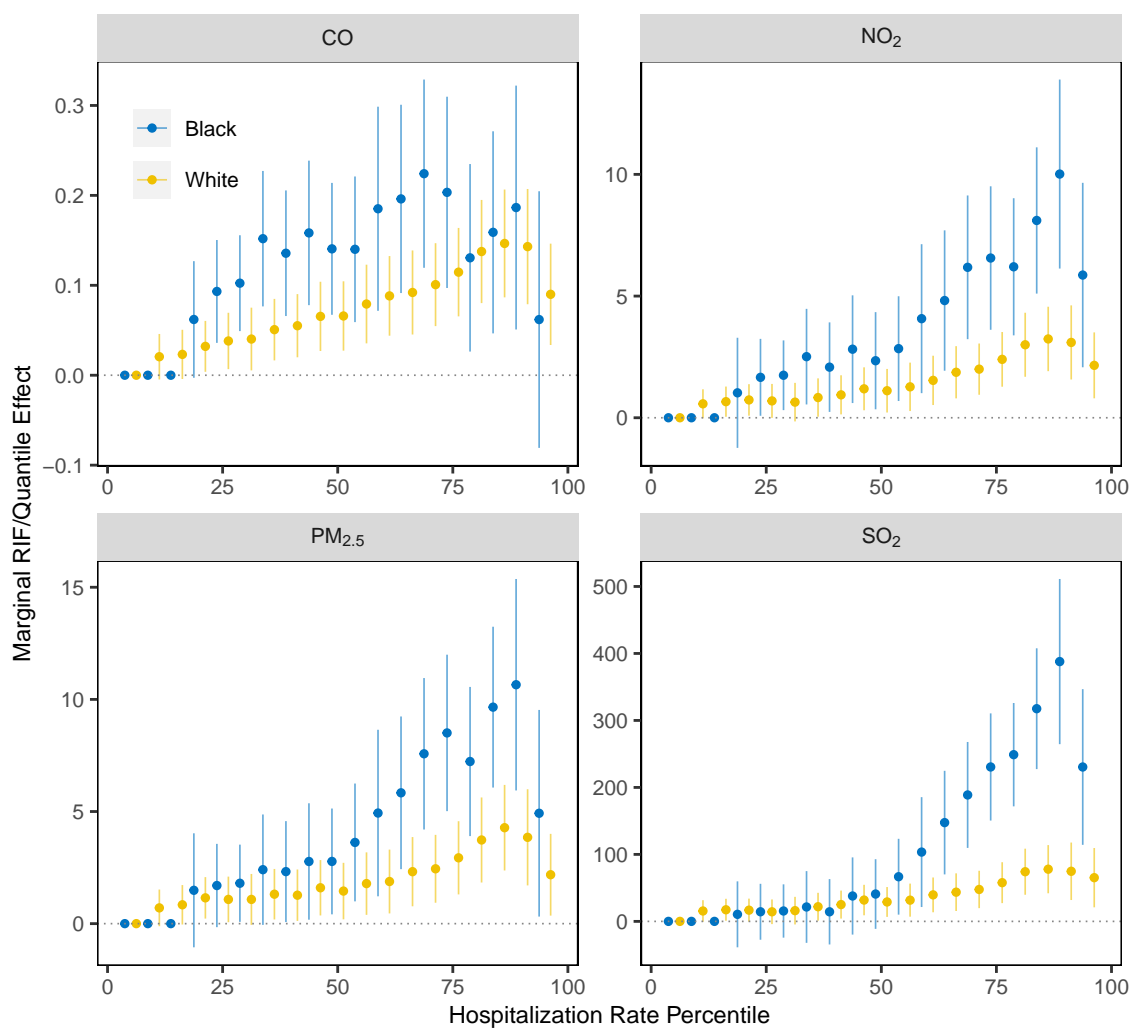

Figure C.1: RIF-quantile effects of pollution on hospitalization rates by race.

Notes: This figure plots the estimates from 38 individual regressions of equation (3) for each air pollutant, with 19 regressions for each race. The dependent variable is the RIF statistics of total hospitalization rate associated with respiratory, heart, and psychiatric ailments for a given quantile. The pollution measures are instrumented by fitted vessel tonnage in ports, wind direction, wind speed, and interactions. All regressions include a set of weather controls, such as the quadratics of maximum, minimum, and dew point temperatures and precipitation. All regressions also include county-by-year, month, day-of-week, holiday, and zip code-port pair fixed effects. Standard errors are clustered by zip code-port pair and day. Estimates are weighted by zip code-specific population. The error bars represent $95 \%$ confidence intervals. 


\section{C.3 Reduced-form Relationship between Vessels in Ports and Health}

This section examines the reduced-form relationship between the number of vessels in ports and human health. We estimate the regression model in equations (1) and (2) by specifying the dependent variable as hospitalization rate across illness categories. We use the ten-day lagged cyclones that are 500 miles distant from ports as the IV in our baseline specification. ${ }^{5}$ Since the IV specification is similar to the one used in the main text, we do not present the results for IV validity checks.

Table C.1 presents the first-stage relationship between the cyclone IV and vessel tonnage in ports. The point estimate is statistically significant, suggesting the cyclone IV leads to a $5 \%$ reduction in vessel tonnage in ports.

Table C.1: First-stage results of the effect of tropical cyclones on vessel tonnage

\begin{tabular}{lc}
\hline \hline & Dependent variable: log of vessel tonnage \\
\hline Tropical Cyclone & $-0.05^{* * *}$ \\
& $(0.02)$ \\
\hline First-stage F Stat. & 10.80 \\
Adjusted $R^{2}$ & 0.70 \\
Observations & $1,812,225$ \\
\hline \hline
\end{tabular}

Notes: This table presents the first-stage results of the IV estimation in Table C.2. The instrument is a dummy of ten-day lagged and 500-mile distant cyclones from ports. All regressions include a set of weather controls, such as the quadratics of maximum, minimum, and dew point temperatures, precipitation, wind speed, and relative wind direction between a zip code-port pair. All regressions also include county-by-year, month, day-of-week, holiday, and zip code-port pair fixed effects. Standard errors are clustered by zip code-port pair and day. Estimates are weighted by zip code-specific population. Significance levels are indicated by *** $1 \%, * * 5 \%$, and * $10 \%$.

Table C.2 presents the IV estimation for the effect of vessel tonnage on hospitalizations across seven illness categories. The t-statistics on the excluded instrument are 11.39 across the columns above the thresholds suggested in the literature. Most estimates associated with respiratory illnesses shown in columns (4)-(6) are statistically significant. They show that a one percent increase in gross vessel tonnage in a port results in an additional 1.07 hospital visits per million residents related to all respiratory illnesses. However, the estimates associated with psychiatric and heart illnesses have surprising signs, and they are either statistically significant at the $10 \%$ level or insignificant. We do not see strong

\footnotetext{
${ }^{5}$ We use the ten-day lagged cyclones here instead of the seven-day lagged ones in the main text because the ten-day lagged cyclones show a stronger correlation in the first stage.
} 
results related to psychiatric and heart illnesses, probably because the composition of air pollutants co-emitted from vessels together may not cause mental and heart illnesses.

Table C.2: Effect of vessel tonnage on contemporaneous hospitalizaton rate in California port areas, IV estimation

\begin{tabular}{|c|c|c|c|c|c|c|}
\hline & \multicolumn{6}{|c|}{ Dependent variable: hospital visits/million residents } \\
\hline & \multicolumn{3}{|c|}{ Respiratory } & \multirow{2}{*}{$\begin{array}{c}\text { Heart } \\
\text { All } \\
\text { Heart } \\
(4)\end{array}$} & \multicolumn{2}{|c|}{ Psychiatric } \\
\hline & $\begin{array}{c}\text { Asthma } \\
\text { (1) }\end{array}$ & $\begin{array}{c}\text { Upper } \\
\text { Respiratory } \\
(2)\end{array}$ & $\begin{array}{c}\text { All } \\
\text { Respiratory } \\
(3)\end{array}$ & & $\begin{array}{c}\text { Anxiety } \\
\text { (5) }\end{array}$ & $\begin{array}{c}\text { All } \\
\text { Psychiatric } \\
(6) \\
\end{array}$ \\
\hline Log of Vessel Tonnage & $\begin{array}{l}13.11^{* *} \\
(6.50)\end{array}$ & $\begin{array}{l}38.17^{* * *} \\
(12.59)\end{array}$ & $\begin{array}{c}108.03^{* * *} \\
(35.15)\end{array}$ & $\begin{array}{l}-1.93 \\
(9.96)\end{array}$ & $\begin{array}{l}-7.74^{*} \\
(4.54)\end{array}$ & $\begin{array}{c}-20.99^{*} \\
(11.98)\end{array}$ \\
\hline $\begin{array}{l}\text { Adjusted } R^{2} \\
\text { Observations }\end{array}$ & $\begin{array}{c}0.36 \\
1,812,225\end{array}$ & $\begin{array}{c}-0.06 \\
1,812,225\end{array}$ & $\begin{array}{c}0.08 \\
1,812,225\end{array}$ & $\begin{array}{c}0.35 \\
1,812,225\end{array}$ & $\begin{array}{c}0.19 \\
1,812,225\end{array}$ & $\begin{array}{c}0.36 \\
1,812,225\end{array}$ \\
\hline
\end{tabular}

Notes: This table presents the IV estimation of the effect of vessel tonnage on the contemporaneous hospitalization rate for the overall population. Each column presents an individual regression on an illness category. The endogenous variable, log of vessel tonnage, is instrumented by the dummy of ten-day lagged and 500mile distant cyclones from ports. All regressions include a set of weather controls, such as the quadratics of maximum, minimum, and dew point temperatures, precipitation, wind speed, and relative wind direction between a zip code-port pair. All regressions also include county-by-year, month, day-of-week, holiday, and zip code-port pair fixed effects. Standard errors are clustered by zip code-port pair and day. Estimates are weighted by the zip code-specific population. Significance levels are indicated by ** 1\%, ${ }^{* *} \%$, and * $10 \%$.

Tables C.3 shows the OLS estimates for the effect of vessel tonnage on hospitalizations. The estimates for respiratory illnesses become insignificant or significant at the $10 \%$ level. They are also much smaller than the corresponding IV estimates, suggesting potential bias. The OLS estimates associated with psychiatric and heart illnesses are positive, but they are with small magnitudes.

Table C.4 contains the IV estimates for the effect of vessel tonnage on hospitalizations by non-Hispanic Black and white populations. Similar to Table C.2, only the estimates associated with respiratory illnesses are statistically significant and have expected signs. They provide additional evidence that port congestion can contribute to racial disparities in respiratory-related health outcomes. 
Table C.3: Effect of vessel tonnage on contemporaneous hospitalizaton rate in California port areas, OLS estimation

\begin{tabular}{|c|c|c|c|c|c|c|}
\hline & \multicolumn{6}{|c|}{ Dependent variable: hospital visits/million residents } \\
\hline & \multicolumn{3}{|c|}{ Respiratory } & \multirow{2}{*}{$\begin{array}{c}\text { Heart } \\
\text { All } \\
\text { Heart } \\
(4)\end{array}$} & \multicolumn{2}{|c|}{ Psychiatric } \\
\hline & $\begin{array}{c}\text { Asthma } \\
\text { (1) }\end{array}$ & $\begin{array}{c}\text { Upper } \\
\text { Respiratory } \\
(2) \\
\end{array}$ & $\begin{array}{c}\text { All } \\
\text { Respiratory } \\
(3)\end{array}$ & & $\begin{array}{c}\text { Anxiety } \\
(5)\end{array}$ & $\begin{array}{c}\text { All } \\
\text { Psychiatric } \\
(6)\end{array}$ \\
\hline Log of Vessel Tonnage & $\begin{array}{c}0.04 \\
(0.07) \\
\end{array}$ & $\begin{array}{c}0.02 \\
(0.08) \\
\end{array}$ & $\begin{array}{l}0.41^{*} \\
(0.24)\end{array}$ & $\begin{array}{l}0.23^{*} \\
(0.12) \\
\end{array}$ & $\begin{array}{l}0.18^{* * *} \\
(0.05)\end{array}$ & $\begin{array}{l}0.41^{* * *} \\
(0.13)\end{array}$ \\
\hline $\begin{array}{l}\text { Adjusted } R^{2} \\
\text { Observations }\end{array}$ & $\begin{array}{c}0.39 \\
1,812,225\end{array}$ & $\begin{array}{c}0.34 \\
1,812,225\end{array}$ & $\begin{array}{c}0.47 \\
1,812,225\end{array}$ & $\begin{array}{c}0.35 \\
1,812,225\end{array}$ & $\begin{array}{c}0.22 \\
1,812,225\end{array}$ & $\begin{array}{c}0.40 \\
1,812,225\end{array}$ \\
\hline
\end{tabular}

Notes: This table presents the OLS estimation of the effect of vessel tonnage on the contemporaneous hospitalization rate. Each column presents an individual regression on an illness category. All regressions include a set of weather controls, such as the quadratics of maximum, minimum, and dew point temperatures, precipitation, wind speed, and relative wind direction between a zip code-port pair. All regressions also include county-by-year, month, day-of-week, holiday, and zip code-port pair fixed effects. Standard errors are clustered by zip code-port pair and day. Estimates are weighted by the zip code-specific population. Significance levels are indicated by ${ }^{* *} 1 \%, * * 5 \%$, and $* 10 \%$. 
Table C.4: Effect of vessel tonnage on contemporaneous hospitalizaton rate by race in port areas of California, IV estimation

\begin{tabular}{|c|c|c|c|c|c|c|}
\hline & \multicolumn{6}{|c|}{ Dependent variable: hospital visits/million residents in each race group } \\
\hline & \multicolumn{3}{|c|}{ Respiratory } & \multirow{2}{*}{$\begin{array}{c}\text { Heart } \\
\text { All } \\
\text { Heart } \\
(4)\end{array}$} & \multicolumn{2}{|c|}{ Psychiatric } \\
\hline & $\begin{array}{c}\text { Asthma } \\
\text { (1) }\end{array}$ & $\begin{array}{c}\text { Upper } \\
\text { Respiratory } \\
(2) \\
\end{array}$ & $\begin{array}{c}\text { All } \\
\text { Respiratory } \\
(3)\end{array}$ & & $\begin{array}{c}\text { Anxiety } \\
\text { (5) }\end{array}$ & $\begin{array}{c}\text { All } \\
\text { Psychiatric } \\
(6)\end{array}$ \\
\hline \multicolumn{7}{|l|}{ Panel A: Black } \\
\hline Log of Vessel Tonnage & $\begin{array}{l}53.81^{*} \\
(28.29) \\
\end{array}$ & $\begin{array}{c}72.63^{* * *} \\
(25.36) \\
\end{array}$ & $\begin{array}{c}267.78^{* * *} \\
(93.30) \\
\end{array}$ & $\begin{array}{c}-5.42 \\
(25.55) \\
\end{array}$ & $\begin{array}{l}-16.22 \\
(10.94) \\
\end{array}$ & $\begin{array}{c}-71.20^{* *} \\
(33.35) \\
\end{array}$ \\
\hline $\begin{array}{l}\text { Adjusted } R^{2} \\
\text { Observations }\end{array}$ & $\begin{array}{c}0.14 \\
888,237\end{array}$ & $\begin{array}{c}-0.01 \\
888,237\end{array}$ & $\begin{array}{c}0.04 \\
888,237\end{array}$ & $\begin{array}{c}0.13 \\
888,237\end{array}$ & $\begin{array}{c}0.04 \\
888,237\end{array}$ & $\begin{array}{c}0.16 \\
888,237\end{array}$ \\
\hline \multicolumn{7}{|l|}{ Panel B: White } \\
\hline Log of Vessel Tonnage & $\begin{array}{c}7.41 \\
(7.18)\end{array}$ & $\begin{array}{c}13.79^{* *} \\
(6.42)\end{array}$ & $\begin{array}{l}61.45^{* *} \\
(28.23)\end{array}$ & $\begin{array}{c}-3.39 \\
(16.74) \\
\end{array}$ & $\begin{array}{l}-8.35 \\
(7.55)\end{array}$ & $\begin{array}{l}-24.83 \\
(19.68)\end{array}$ \\
\hline Adjusted $\mathrm{R}^{2}$ & 0.17 & 0.05 & 0.26 & 0.28 & 0.14 & 0.31 \\
\hline Observations & $1,687,172$ & 1,687,172 & 1,687,172 & 1,687,172 & 1,687,172 & 1,687,172 \\
\hline
\end{tabular}

Notes: This table presents the IV estimation of the effect of vessel tonnage on the contemporaneous hospitalization rate for the Black and white populations. Each entry presents an individual regression on an illness category. The endogenous variable, log of vessel tonnage, is instrumented by the dummy of ten-day lagged and 500-mile distant cyclones from ports. All regressions include a set of weather controls, such as the quadratics of maximum, minimum, and dew point temperatures, precipitation, wind speed, and relative wind direction between a zip code-port pair. All regressions also include county-by-year, month, day-of-week, holiday, and zip code-port pair fixed effects. Standard errors are clustered by zip code-port pair and day. Estimates are weighted by the zip code-specific population. Significance levels are indicated by ${ }^{* * *} 1 \%,{ }^{* *} 5 \%$, and ${ }^{*} 10 \%$. 


\section{National Energy Modeling System (For Online Publica- tion)}

The National Energy Modeling System (NEMS) is an integrated energy-economy modeling system developed by EIA. A 2017 version of NEMS is currently hosted on a server at Yale University, and we call it Yale-NEMS at EIA's request. Yale-NEMS comprises 13 modules comprehensively modeling major energy supply sectors, conversion sectors, demand markets, macroeconomics, and international energy markets. The model simulates energy markets out to 2050 subject to a comprehensive set of constraints, such as economics, technological advancement, demographics, resource availability, and behavior assumptions. The model also includes current energy and environmental policies at the state and federal levels, while it does not consider any proposed rule-makings. Model projections include energy consumption, production, trade, prices, and emissions.

Since we are particularly interested in the effects of shore-side energy consumption and its interaction with the power sector, this appendix discusses how Yale-NEMS models marine fuel consumption and electricity generation. The description of other modules is available at EIA (2009). We first introduce the reference case of Yale-NEMS, which we use as the baseline for our analysis.

\section{D.1 Annual Energy Outlook}

We take Annual Energy Outlook (AEO) 2017 as the reference case. AEO 2017 is a regular update of the U.S. energy market outlook, released in early 2017 by EIA. The series of AEOs have been widely referenced for decision makings by government agencies, academia, and private sectors for decades. AEO 2017 projects a time path of key U.S. energy market indicators from present to 2050 EIA (2017a). Comparing to previous annual outlooks, AEO 2017 includes two reference projections, one including the Clean Power Plan (CPP) and the other excluding it. Because the CPP is much less stringent than its original form, in this study, we use AEO 2017 without the Clean Power Plan as the reference case.

While AEO 2017 is a few years old, electricity generation in the United States has only become cleaner since 2017. Thus, if our simulation results are biased in any direction, they would be biased towards overestimating the air pollution from electricity consumption. This suggests that using AEO 2021 would only strengthen our results that the California port electrification regulation reduced air pollution emissions on net. 


\section{D.2 Marine Energy Consumption}

In Yale-NEMS, the transportation demand module projects transit and auxiliary fuel consumption by marine vessels, within the U.S. Emission Control Area-the areas within 200 nautical miles of the U.S. coast and outside ECA EIA (2016).

Yale-NEMS models the marine fuel consumption by vessel type (tanker, container, gas (LPG/LNG), roll-on/roll-off, bulk, and general cargo) within the ECA in three steps, as is discussed in great detail in EIA (2016). First, the model estimates the total energy consumption in a base year (2013) based on historical data. From the base year, the model then determines the projections of energy demand in future years by several factors: fleet turnover rate-representing the rate of new vessels entering a fleet moving through ECA, marine fuel efficiency improvement, and industrial output-accounting for economic growth. Third, the model splits total energy consumption into four fuel types, including distillate oil, residual oil, CNG, and LNG, based on fuel price changes using a logit model specification.

EIA's NEMS does not explicitly model port-side electricity consumption and we add this feature to Yale-NEMS. First, we obtain historical data on vessel visits connected to onshore electricity and compare them to the total number of visits, which provides us the approximate percentage of energy consumption from electricity by year and region. For future years, we assume the same proportion of using electricity from 2016. We also incorporate the California Ocean-Going Vessel At-Berth Regulation (see Section 6.1 for details). Second, since we know the total fossil fuel consumption in ECA, we calculate the total electricity consumption based on the calculated percentages, constituting the reference shore-side electricity consumption in the model. Third, we subtract the newly added marine electricity demand from the total commercial electricity demand. Thus the total electricity demand across sectors is still comparable to the AEO 2017 base projections. Fourth, we calculate the reference emissions from vessels by applying the emission factors by engine type (transit and auxiliary) and fuel type to total fuel consumption.

\section{D.3 Electricity Generation}

The Electricity Market Module (EMM) in Yale-NEMS explicitly models the U.S. electricity market and its interaction with other energy markets EIA (2017b). The module is at the North American Electric Reliability Corporation (NERC) region level. In each modeling year, other interrelated modules pass critical parameters to the EMM, including electricity demand from the four end-use demand modules (commercial, industrial, residential, and transportation demand), input fuel prices from the fuel supply modules (coal, natural gas, 
and fuel oils), and macroeconomic expectations from the macroeconomic module. The EMM then makes production decisions by choosing a fuel mix to generate electricity to meet demand cost-efficiently with perfect foresight.

The outputs from the EMM include electricity quantities and prices, input fuel consumption, emissions, and capital investment for additional capacity, which are then all returned to the related modules. Several factors determine the total emissions from generating electricity, including emission factors across energy types and mitigation technologies. The model iterates until market equilibrium achieves. The electricity consumption from ports is linked to EMM. When there is electricity incurred by vessels, the demand is received by the EMM, and then the EMM generates electricity to meet such demand most economically.

Yale-NEMS only reports emissions of $\mathrm{SO}_{2}$ and $\mathrm{NO}_{x}$ from the power sector. To evaluate $\mathrm{PM}_{2.5}$, we use an approximation approach similar to Gillingham and Huang $(2019,2020)$. First, we calculate the base year (2014) $\mathrm{PM}_{2.5}$ emissions from power plants based on the EPA 2014 National Emissions Inventory (NEI) data and obtain the energy consumption from Yale-NEMS in the same year. Second, we extrapolate the emissions after 2014 as a constant proportion of energy consumption.

\section{D.4 Shore Power Scenario}

We construct a shore power scenario, in which all U.S. ports implement shore power for auxiliary engines of vessels. Specifically, we allow auxiliary fuels (e.g., distillate oil, residual oil, and natural gas) consumed by vessels to be gradually replaced by electricity generated by power plants from 2020 to 2025, and after 2025 all auxiliary engines are powered by electricity. The fuel switch follows the following linear adjustment:

$$
\begin{aligned}
q_{f, t} & =\left(1-\frac{t-2019}{2025-2019}\right) q_{f, t^{\prime}}^{0} \\
q_{e, t} & =\frac{t-2019}{2025-2019} \sum_{f} q_{f, t^{\prime}}^{0}
\end{aligned}
$$

where $q_{f, t}^{0}$ represents the consumption of auxiliary fuel $f$ by vessels in ports in year $t$ $(t<2025)$ in the reference case and $q_{f, t}$ is the adjusted fuel consumption in the Shore Power scenario. $q_{e, t}$ is electricity consumption by vessels in ports switched from fossil fuels. From the year 2025 onwards, fossil fuels consumed by auxiliary engines are entirely replaced with electricity, as represented in the following: 


$$
\begin{aligned}
& q_{f, t}=0, \\
& q_{e, t}=\sum_{f} q_{f, t}^{0} .
\end{aligned}
$$

We run the reference case and the Shore Power scenario individually in Yale-NEMS. We then compare the emissions results between the two cases, and the differences indicate the effect of implementing shore power in ports.

\section{References for Appendices}

Bell, M. L., Ebisu, K., Peng, R. D., Walker, J., Samet, J. M., Zeger, S. L., and Dominici, F. (2008). Seasonal and regional short-term effects of fine particles on hospital admissions in 202 US counties, 1999-2005. American Journal of Epidemiology, 168(11):1301-10.

Dominici, F., Peng, R. D., Bell, M. L., Pham, L., McDermott, A., Zeger, S. L., and Samet, J. M. (2006). Fine particulate air pollution and hospital admission for cardiovascular and respiratory diseases. JAMA, 295(10):1127-34.

EIA (2009). The National Energy Modeling System: An Overview 2009. Technical report, United State Energy Information Administration, Washington, DC.

EIA (2016). Transportation Sector Demand Module of the National Energy Modeling System: Model Documentation. Technical report, United States Energy Information Administration, Washington, DC.

EIA (2017a). Annual Energy Outlook 2017. Technical report, U.S. Energy Information Administration, Washington, DC.

EIA (2017b). Electricity Market Module of the National Energy Modeling System: Model Documentation. Technical report, United States Energy Information Administration, Washington, DC.

EPA (2003). Control of Emissions From New Marine Compression-Ignition Engines at or Above 30 Liters Per Cylinder. Technical report, United States Environmental Protection Agency, Washington, DC.

Firpo, S., Fortin, N. M., and Lemieux, T. (2009). Unconditional Quantile Regressions. Econometrica, 77(3):953-973. 
Gillingham, K. and Huang, P. (2019). Is abundant natural gas a bridge to a low-carbon future or a dead-end? Energy Journal, 40(2):1-26.

Gillingham, K. and Huang, P. (2020). Long-Run Environmental and Economic Impacts of Electrifying Waterborne Shipping in the United States. Environmental Science \& Technology, 54(16):9824-9833.

Hwang, J. S. and Chan, G. C. (2002). Effects of air pollution on daily clinic visits for lower respiratory tract illness. American Journal of Epidemiology, 155(1):1-10.

Peel, J. L., Tolbert, P. E., Klein, M., Metzger, K. B., Flanders, W. D., Todd, K., Mulholland, J. A., Ryan, P. B., and Frumkin, H. (2005). Ambient air pollution and respiratory emergency department visits. Epidemiology, 16(2):164-174.

Schlenker, W. and Walker, W. R. (2016). Airports, air pollution, and contemporaneous health. Review of Economic Studies, 83(2):768-809.

Stieb, D. M., Szyszkowicz, M., Rowe, B. H., and Leech, J. A. (2009). Air pollution and emergency department visits for cardiac and respiratory conditions: a multi-city timeseries analysis. Environmental Health, 8:25. 